\title{
Mineral Matter in the Late Permian C1 Coal from Yunnan Province, China, with Emphasis on Its Origins and Modes of Occurrence
}

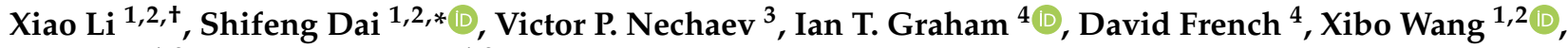 \\ Lei Zhao ${ }^{1,2}$ and Jingtao Zhao ${ }^{1,2}$
}

1 State Key Laboratory of Coal Resources and Safe Mining, China University of Mining and Technology, China; xiao223623@126.com (X.L.); xibowang@gmail.com (X.W.); lei.zhao@y7mail.com (L.Z.); diffzjt@163.com (J.Z.)

2 College of Geoscience and Survey Engineering, China University of Mining and Technology, Beijing 100083, China

3 Far East Geological Institute, Far Eastern Branch, Russian Academy of Sciences, 690022 Vladivostok, Russia; vnechaev@hotmail.com

4 School of Biological, Earth and Environmental Sciences, University of New South Wales, Sydney, NSW 2052, Australia; i.graham@unsw.edu.au (I.T.G.); davidfrench474@gmail.com (D.F.)

* Correspondence: daishifeng@gmail.com or dsf@cumtb.edu.cn

+ Current address: Teaching center of Experiment and Practice, Hebei GEO University, Shijiazhuang 050031, China.

check for updates

Citation: Li, X.; Dai, S.; Nechaev, V.P.; Graham, I.T.; French, D.; Wang, X.; Zhao, L.; Zhao, J. Mineral Matter in the Late Permian C1 Coal from Yunnan Province, China, with Emphasis on Its Origins and Modes of Occurrence. Minerals 2021, 11, 19. https://doi.org/10.3390/min11010019

Received: 9 November 2020 Accepted: 22 December 2020 Published: 25 December 2020

Publisher's Note: MDPI stays neutral with regard to jurisdictional claims in published maps and institutional affiliations.

Copyright: () 2020 by the authors. Licensee MDPI, Basel, Switzerland. This article is an open access article distributed under the terms and conditions of the Creative Commons Attribution (CC BY) license (https: / / creativecommons.org/ licenses/by/4.0/).

\begin{abstract}
This paper reports the mineralogy and geochemistry of the Late Permian C1 Coal from Bole and Laibin mines in eastern Yunnan, Southwestern China (C1 Coal in Laibin mine is composed of three layers termed B1, B2, and B3). The coals are characterized by medium-high ash yields and very low sulfur contents. Compared with average values of trace element concentrations in hard coals worldwide, the Bole and Laibin coals are enriched in $\mathrm{V}, \mathrm{Co}, \mathrm{Cu}, \mathrm{Zn}$, and Se, which were mainly derived from the sediment-source region of the Kangdian Upland. Major minerals in the coal samples and roof and floor strata include quartz, interstratified berthierine/chamosite (B/C), as well as kaolinite, mixed layer illite/smectite, calcite, pyrite, and anatase. Unlike a pure chamosite, the $7 \AA$ peak of interstratified B/C is sharp and narrow, while the $14 \AA$ peak is broad and weak, or absent in some coal samples. Interstratified B/C was largely precipitated from low-temperature Fe-rich and Mg-rich hydrothermal fluids or, in some cases, is an alteration product of kaolinite. Secondary phases of quartz, calcite, pyrite, kaolinite, chalcopyrite, gypsum, and REE-phosphates in the coal samples are the dominant authigenic minerals formed at syngenetic and early diagenetic stages. Four intra-seam partings in C1 Coal, B1, and B3 layers are identified as tonsteins derived from felsic volcanic ashes. These tonsteins consist mainly of cryptocrystalline kaolinite with graupen and vermicular textures, and minor amounts of high-temperature quartz, zircon, apatite, monazite, and anatase. The floor of the $\mathrm{C} 1 \mathrm{Coal}$ in the Bole mine is a tuffaceous claystone and consists of altered high-Ti basalt volcaniclastics, characterized by high concentrations of $\mathrm{Zr}, \mathrm{Nb}, \mathrm{V}, \mathrm{Co}, \mathrm{Cu}$, and $\mathrm{Zn}$, low $\mathrm{Al}_{2} \mathrm{O}_{3} / \mathrm{TiO}_{2}$ ratio ( 4.62), high Ti/Y ratio ( 900), enrichment of middle rare earth elements, and positive Eu anomalies.
\end{abstract}

Keywords: Late Permian coals; minerals in coal; elements in coal; interstratified berthierine/chamosite; tonsteins; Eastern Yunnan

\section{Introduction}

As with the organic matter in coal, mineral matter is also an important component that significantly influences coal quality [1-3]. The abundance, modes of occurrence, and assemblage of mineral matter in coal can provide useful information not only on the conditions of peat deposition, subsequent diagenetic and epigenetic processes, and the 
regional tectonic history [4,5], but also on assessing the environmental and health impacts of coal processing and utilization [6-9].

Mineral matter in coal is formed by a range of different processes [2,10], including detrital input from the sediment source region [11-13], accumulation of biogenic components [14], precipitation from solutions [15], deposition of volcanic ashes [16,17], and diagenetic and epigenetic alteration. The former two processes are universal in coal deposits worldwide, while volcanic-influenced coals and intra-seam partings of volcanic origin (i.e., tonstein) have also been observed in many coal deposits $[10,18]$. The altered volcanic ash layers have been used in some areas as stratigraphic markers or for radiometric age determination if suitable primary minerals (such as sanidine, zircon, and monazite) are present. The mineral matter in altered volcanic ashes can also be used to explain the geologic history and mass extinction events $[10,19]$. Practically, volcanic ashes in coal may lower the quality of the coal but alkali volcanic ashes may be the cause of significantly enriched critical elements such as $\mathrm{Nb}, \mathrm{Ta}, \mathrm{Zr}, \mathrm{Hf}, \mathrm{Y}$, and rare earth elements in coal $[10,20,21]$.

The Late Permian coals from Eastern Yunnan, Southwestern China, have attracted much attention not only because they contain useful records of contemporaneous volcanism during peat deposition and the evolution of the Emeishan mantle plume [12,20-25], but also the mineral matter concentrated in the coals (e.g., nano-quartz $[26,27]$ or Ferich aluminosilicates [28] in coal in Xuanwei), which is released during coal indoor combustion, leading to the highest female lung cancer mortality rate in the world [26-28]. Nanoquartz in the Xuanwei coals was once considered the carcinogen responsible for the high lung cancer rates in the area [26,27]. Although some studies have already found abundant Fe-rich aluminosilicates (e.g., chamosite) in the coals from Xuanwei and adjacent areas $[27,29,30]$, it has just been recognized that chamosite is the newly suspected carcinogen, which plays a significant role in the carcinogenesis pathway by activating inflammatory reactions [28]. There are a number of coal seams in this area. However, not all coals but just $\mathrm{C} 1 \mathrm{Coal}$ is considered the source responsible for lung cancer [27]. It is interesting that abundant Fe-rich aluminosilicate, i.e., interstratified berthierine/chamosite $(B / C)$, was identified in this coal seam in this study but has rarely been previously reported elsewhere [3]. However, it is a common mineral in modern sediments and sedimentary rocks, particularly ironstones [31-35]. Additionally, chlorite is present in coals with different forms such as chamosite $\left.\left[\mathrm{Fe}^{2+}{ }_{6}\left(\mathrm{Fe}^{2+}{ }_{4}, \mathrm{Al}_{2}\right)\left[\mathrm{Si}_{6}, \mathrm{Al}_{2}\right) \mathrm{O}_{20}\right](\mathrm{OH})_{16}\right]$, cookeite $\left.\left[\mathrm{Al}_{4}\left(\mathrm{Li}_{2}, \mathrm{Al}_{4}\right)\left[\mathrm{Si}_{6}, \mathrm{Al}_{2}\right) \mathrm{O}_{20}\right](\mathrm{OH})_{16}\right]$, pennantite $\left.\left[\mathrm{Mn}^{2+}{ }_{6}\left(\mathrm{Mn}^{2+}{ }_{4}, \mathrm{Al}_{2}\right)\left[\mathrm{Si}_{6}, \mathrm{Al}_{2}\right) \mathrm{O}_{20}\right](\mathrm{OH})_{16}\right]$, and clinochlore $\left[\mathrm{Mg}_{5} \mathrm{Al}\left(\mathrm{AlSi}_{3} \mathrm{O}_{10}\right)(\mathrm{OH})_{8}\right]$ [3]. Different forms of chlorite in coal not only have various chemical compositions but also have formed under different conditions in various stages of coal formation. Precise identification of different forms of chlorite is critical to understand the sources of minerals in coal and the geological processes to which coal has been subjected, and, more importantly, to help with identifying the source responsible for the lung cancer. Therefore, the purpose of this study is to investigate the mineral matter in the C1 Coal and in associated altered volcanic ash layers (including four tonsteins and one floor stratum) from the Bole and Laibin mines (eastern Yunnan, Southwestern China), with special emphasis focusing on the high $\mathrm{B} / \mathrm{C}$ content in the coal samples.

\section{Geological Setting}

The Bole and Laibin mines are located in the Northeastern Yunnan Province, Southwestern China (Figure 1). Tectonically, Northeastern Yunnan is located in the Southwestern Upper Yangtze block, which was uplifted by the Dongwu movement in the late Middle Permian [36]. The Maokou Formation limestone was concurrently elevated due to the Dongwu movement and, subsequently, has been subjected to intensive weathering and erosion. Subsequently, the eruption of voluminous Emeishan flood basalts, which covered an area of more than $2.5 \times 105 \mathrm{~km}^{2}$ with a thickness ranging from several hundred meters to $5 \mathrm{~km}$, resulted in the formation of the Kangdian Upland [37,38]. The Kangdian Upland mainly consists of basalts ( $95 \%$ by volume) and associated pyroclastics, along with minor 
trachytes and rhyolites at the top of the sequence [39-42]. During the entire Late Permian, the Upper Yangtze block was elevated in the west and subsided in the east, leading to the sedimentary environments and varying from piedmont alluvial plain through littoral alluvial plain (basal clinoform) to a littoral plain from west to east (Figure 1) [12,29]. Therefore, the Kangdian Upland was the major sediment source region for the coal basins situated in Eastern Yunnan, Western Guizhou, and Southern Sichuan provinces [34].

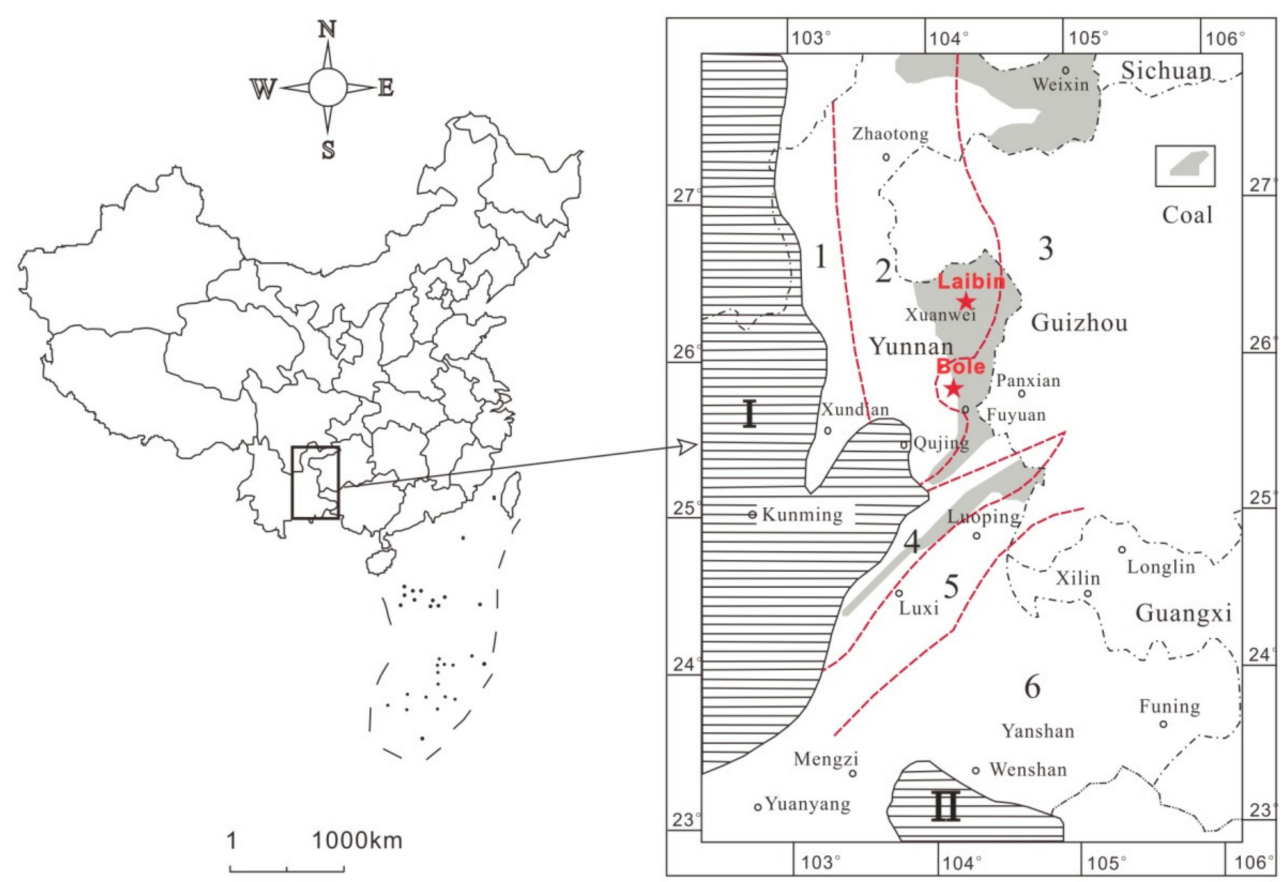

Figure 1. Location of the Bole and Laibin Coal Mines and distribution of depositional environments during the Late Permian in the Eastern Yunnan Province, China. I: Kangdian Upland. II: Northern Vietnam Upland. 1: Piedmont alluvial plain. 2: Littoral alluvial plain (basal clinoform). 3: Littoral plain. 4: Epicontinental littoral clinoform. 5: Luxi-Luoping submarine trench. 6: Restricted carbonate platform. Modified from Dai et al. [29].

The coal-bearing sequence of Late Permian in the Bole and Laibin mines is the Xuanwei Formation (Figure 2), overlying the Late Permian Xuanwuyan Formation and overlain by the Early Triassic Kayitou Formation. The Xuanwei Formation $\left(\mathrm{P}_{3} \mathrm{x}\right)$, deposited in a continental environment, is mainly composed of fine-grained sandstone, siltstone, mudstone, and coal seams [36]. The C1 coal is the major mineable seam in the Bole mine and correlates to three layers, i.e., B1, B2, and B3, in the Laibin mine (Figure 2). All are located in the uppermost Xuanwei Formation. The thicknesses (partings included) of the B1, B2, and B3 layers and C1 coal seams at the sampling locations of this study are $0.80,0.92,0.93$, and $1.63 \mathrm{~m}$, respectively. Like most coal seams in other areas, the roof and floor strata in this area consist of terrigenous siltstone, argillaceous siltstone, and mudstone, except for the floor of the $\mathrm{C} 1 \mathrm{Coal}$ in Bole mine (C1-2f), which comprises tuffaceous claystone, as described below. Uncommonly, floor strata of the coal seams are comprised of tuffaceous claystone [12]. The four partings (with an average thickness of $6 \mathrm{~cm}$ ), occurring within the C1 Coal, B1, and B3 layers (Figure 2), are macroscopically (observed from the working faces in the underground coal mines) and microscopically (described below) identified as tonsteins. 


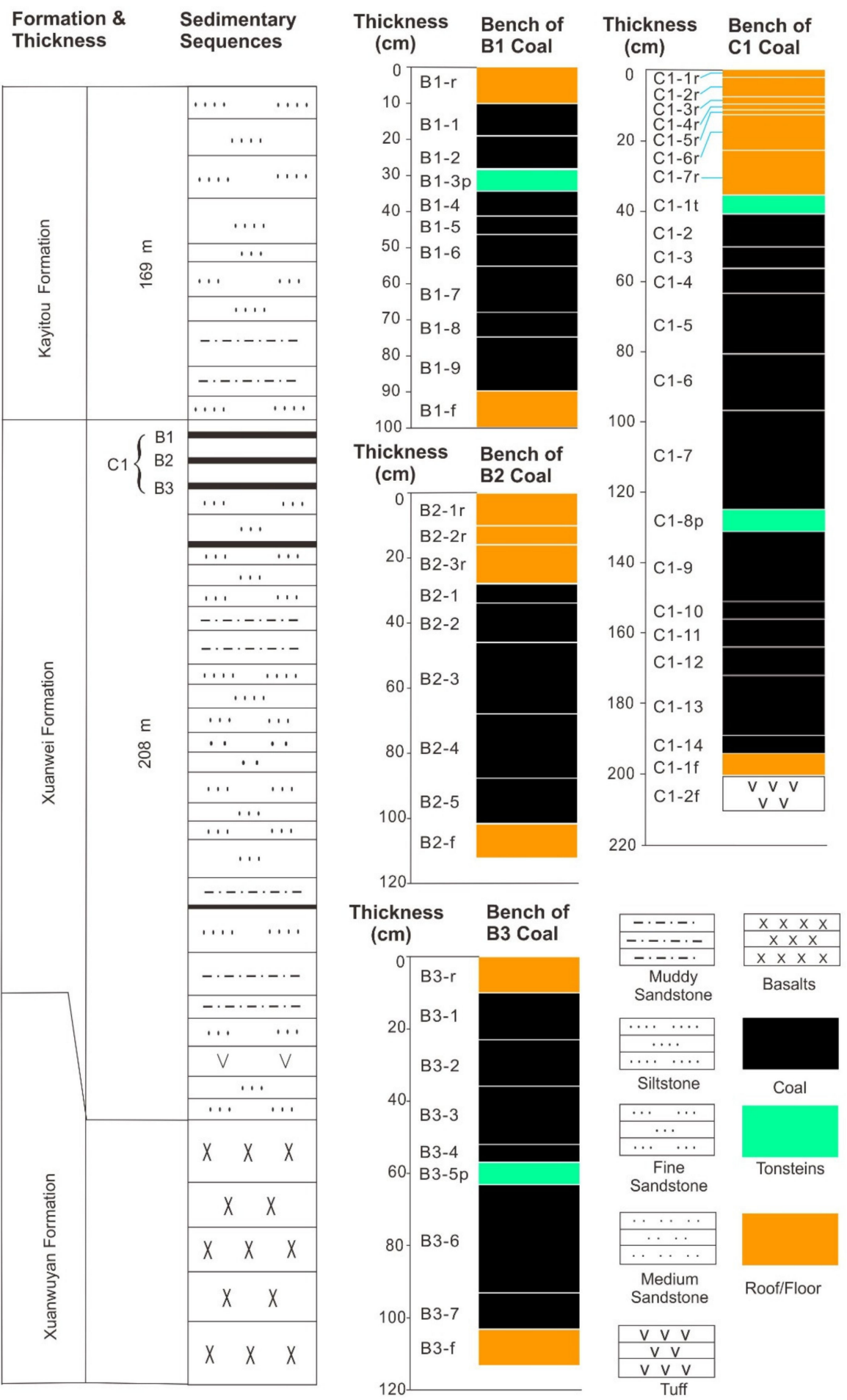

Figure 2. Sedimentary sequences in the Laibin Coal Mine (Modified from Dai et al. [29]) and the collected bench samples (B1, B2, B3, and C1 coals) through the section in the present study. Samples of C1 Coal were collected from the Bole Mine. Samples of B1, B2, and B3 layers were collected from Laibin Mine. Note that $\mathrm{C} 1-2 \mathrm{f}$ is tuffaceous claystone.

\section{Samples and Methods}

The samples were taken from the working faces of the mined coal seams from the Laibin (B1, B2, and B3 layers) and Bole mines (C1 Coal). A total of 29 samples were collected from the B1, B2, and B3 layers including five roof rocks, 19 coal benches, two partings, and three floor strata (Figure 2). A total of 23 samples were collected from the C1 Coal, 
including 12 coal benches, two partings, seven roof, and two floor rocks. The roof and floor strata samples, which were collected for better understanding of the depositional environment of the palaeopeat. The roof, parting and floor samples are identified by the suffixes $-r,-p$, and $-f$, respectively, with the exception of sample C1-1t, which is identified as a tonstein, but it directly underlies the roof strata. The stratigraphy of the bench samples for the four coal seams is presented in Figure 2. Each coal bench was cut from an area about $10-\mathrm{cm}$ wide and $10-\mathrm{cm}$ deep (i.e., digging $10 \mathrm{~cm}$ inside the wall). All collected samples were immediately stored in plastic bags to ensure as little contamination and oxidation as possible. The samples were first pulverized to 1-mm particles by a hammer for pellet preparation for the petrological study. Samples for proximate analysis were pulverized to a No. $60(250-\mu \mathrm{m})$ sieve based on ASTM standards. Samples for X-ray diffraction (XRD) and major and trace element analyses were then further crushed and ground to less than $75 \mu \mathrm{m}$.

Proximate analysis, including moisture content, volatile matter, and ash yield, was performed in accordance with ASTM D3173/D3173M-17a [43], ASTM D3174-12 [44], and ASTM D3175-18 [45], respectively. The total sulfur was determined following ASTM Standard D4239-18e1 [46]. Oxides of the major elements $\left(\mathrm{SiO}_{2}, \mathrm{TiO}_{2}, \mathrm{Al}_{2} \mathrm{O}_{3}, \mathrm{Fe}_{2} \mathrm{O}_{3}, \mathrm{MnO}\right.$, $\mathrm{MgO}, \mathrm{CaO}, \mathrm{Na}_{2} \mathrm{O}, \mathrm{K}_{2} \mathrm{O}$, and $\left.\mathrm{P}_{2} \mathrm{O}_{5}\right)$ in high-temperature ash $\left(815^{\circ} \mathrm{C}\right)$ of the powdered samples were determined by $\mathrm{X}$-ray fluorescence spectrometry (XRF; ARL ADVANT' $\mathrm{XP}^{+}$). The determination of $\mathrm{Hg}$ concentrations in the samples was performed using a Milestone DMA-80 analyzer, following the procedures described by Liu et al. [47]. Fluorine in the samples was determined by pyro-hydrolytic extraction in conjunction with an anionselective electrode, following ASTM D5987-96 [48]. Other trace elements in samples were determined using inductively coupled plasma mass spectrometry (Thermo Fisher, $\mathrm{X}$ series II, ICP-MS), following the procedures as described by Dai et al. [49]. Arsenic and Se were also determined by ICP-MS, but a mixture of $\mathrm{He}$ and $\mathrm{H}_{2}$ was used in the optimized hexapole collision cell, following the procedures described by Li et al. [50]. For boron determination, additional $\mathrm{H}_{3} \mathrm{PO}_{4}$ was added during the sample digestion process, and $2 \%$ ammonia solution was used to eliminate the memory effect of boron during the ICP-MS determination process [51].

The mean random vitrinite reflectance $\left(R_{o, \text { ran }}\right)$ was determined on a polished epoxymounted block coal samples using a Leica DM 4500P microscope (at a magnification of $500 \times$ ) equipped with a Craic QDI $302^{\mathrm{TM}}$ spectrophotometer based on ASTM Standard D2798-11a [52].

Mineral phases were identified by optical microscopy and X-ray diffraction (XRD) of powdered samples. Low-temperature ashing of the coals was performed using an EMITECH K1050X Plasma Asher, prior to XRD analysis. The XRD analysis for the lowtemperature ashes (LTAs) and non-coal samples was performed on a powder diffractometer with Ni-filtered $\mathrm{Cu}-\mathrm{K} \alpha$ radiation and a scintillation detector. The XRD pattern was recorded with a $2.6-70^{\circ} 2 \theta$ interval and a $0.02^{\circ}$ step size. The diffractograms were then subjected to quantitative mineralogical analysis using the commercial interpretation software Siroquant Version 3.0. Further details indicating the use of this technique for coal-related materials have been described by Ward et al. [53,54] and Ruan and Ward [55]. Oriented aggregates of the clay fraction $(<2 \mu \mathrm{m})$ separated from several coal LTAs were also analyzed by XRD, following the method as described by Wang et al. [25].

Scanning electron microscopy (SEM, FEI Quanta 650 FEG) equipped with an energydispersive X-ray spectrometer (EDS, EDAX Genesis Apex 4) was used to study the mineral morphology of selected coal and rock samples, and also to determine the distribution of some elements in the minerals. The selected sample briquettes were carbon-coated before SEM-EDS analyses. SEM images were captured by a retractable solid-state backscatter electron detector with a $20.0-\mathrm{kV}$ beam voltage, $10-\mathrm{mm}$ working distance, and a 5.0-spot size setting. 


\section{Results}

\subsection{Coal Chemistry and Vitrinite Reflectance}

According to the ASTM classification ASTM D388-12 [56], the volatile matter contents and vitrinite reflectance (Table 1) indicate that most Laibin coals are medium volatile bituminous coal and the Bole coals are all high volatile bituminous coal. The reason why the rank of C1 Coal is much lower than those of B1, B2, and B3 layers is not clear and needs further investigation. The ash yields of Bole and Laibin coals are $23.23-69.54 \%$ and $12.17-65.05 \%$, respectively, classified as medium-high-ash to high-ash coals according to Chinese Standards GB/T 15224.1-2010 [57], except that C1-5 and C1-7 are low-medium-ash coals. Although, according to International Classification of in-Seam Coals [58], some samples with ash yields higher than $50 \%$ (Table 1 ) should not be classified as coal. They are actually mined as coal and, therefore, are considered as high-ash coals in this study. The Bole and Laibin coals are characterized by low sulfur contents $(0.22-0.83 \%$ and $0.07-1.07 \%$, respectively, coals with total sulfur $<1 \%$ are low-sulfur coals [59]), which is consistent with the sedimentary environment of a littoral alluvial plain in the area (Figure 1) $[12,29,36]$.

Table 1. Thickness (cm), proximate analysis (\%), total sulfur $(\%)$, and random vitrinite reflectance $(\%)$ of collected samples from B1, B2, B3, and C1 coal seams.

\begin{tabular}{|c|c|c|c|c|c|c|}
\hline Sample & Thickness & $\mathbf{M}_{\mathrm{ad}}$ & $\mathbf{A}_{\mathrm{d}}$ & $\mathbf{V}_{\text {daf }}$ & $S_{t, d}$ & $\mathbf{R}_{\mathbf{0} \text {,ran }}$ \\
\hline B1-1 & 9 & 1.64 & 60.26 & 34.75 & 0.42 & 1.23 \\
\hline B1-2 & 9 & 0.58 & 45.82 & 32.15 & 0.38 & 1.23 \\
\hline B1-4 & 7 & 0.63 & 32.04 & 27.96 & 0.52 & 1.03 \\
\hline B1-5 & 5 & 0.68 & 34.94 & 26.24 & 0.42 & 1.25 \\
\hline B1-6 & 9 & 0.53 & 33.00 & 30.12 & 0.32 & 1.11 \\
\hline B1-7 & 13 & 0.64 & 30.04 & 27.90 & 0.28 & 1.27 \\
\hline B1-8 & 7 & 0.49 & 53.56 & 27.18 & 0.22 & 1.19 \\
\hline B1-9 & 15 & 0.66 & 23.94 & 28.84 & 0.38 & 1.22 \\
\hline WA-B1 & $74^{*}$ & 0.73 & 37.50 & 29.54 & 0.36 & 1.20 \\
\hline B2-1 & 6 & 0.83 & 60.07 & 42.60 & 0.38 & 1.13 \\
\hline B2-2 & 12 & 1.35 & 69.54 & 43.37 & 0.41 & 1.16 \\
\hline B2-3 & 22 & 0.57 & 26.77 & 27.18 & 0.25 & 1.21 \\
\hline B2-4 & 20 & 0.57 & 26.55 & 28.82 & 0.27 & 1.17 \\
\hline B2-5 & 14 & 0.61 & 36.10 & 28.92 & 0.44 & 1.18 \\
\hline WA-B2 & $74 *$ & 0.72 & 38.11 & 31.83 & 0.33 & 1.18 \\
\hline B3-1 & 13 & 0.62 & 40.96 & 29.87 & 0.83 & 1.18 \\
\hline B3-2 & 13 & 0.63 & 28.62 & 27.71 & 0.53 & 1.23 \\
\hline B3-3 & 16 & 0.58 & 27.34 & 27.82 & 0.51 & 1.12 \\
\hline B3-4 & 5 & 0.89 & 23.23 & 28.78 & 0.66 & 1.13 \\
\hline B3-6 & 30 & 0.84 & 23.45 & 26.44 & 0.44 & 1.13 \\
\hline B3-7 & 10 & 0.67 & 34.54 & 28.08 & 0.31 & 1.17 \\
\hline WA-B3 & $87 *$ & 0.71 & 28.81 & 27.72 & 0.52 & 1.15 \\
\hline C1-2 & 9 & 2.22 & 45.20 & 37.20 & 0.28 & 0.68 \\
\hline C1-3 & 6 & 3.74 & 26.30 & 38.60 & 0.75 & 0.67 \\
\hline C1-4 & 7 & 3.23 & 25.45 & 35.99 & 0.93 & 0.69 \\
\hline C1-5 & 17 & 5.22 & 20.00 & 38.64 & 0.65 & 0.65 \\
\hline C1-6 & 16 & 2.64 & 29.16 & 41.30 & 0.35 & 0.61 \\
\hline C1-7 & 28 & 5.21 & 12.17 & 38.75 & 0.53 & 0.57 \\
\hline C1-9 & 20 & 3.35 & 36.24 & 38.66 & 0.07 & 0.73 \\
\hline C1-10 & 5 & 2.25 & 36.18 & 30.47 & 0.03 & 0.69 \\
\hline C1-11 & 8 & 5.72 & 20.24 & 36.23 & 0.40 & 0.65 \\
\hline C1-12 & 8 & 3.40 & 23.88 & 36.58 & 0.44 & 0.63 \\
\hline C1-13 & 17 & 3.46 & 42.25 & 38.99 & 1.07 & 0.71 \\
\hline C1-14 & 5 & 3.99 & 65.05 & 42.54 & 0.45 & 0.63 \\
\hline WA-C1 & $146^{*}$ & 3.92 & 28.71 & 38.39 & 0.51 & 0.65 \\
\hline
\end{tabular}

M: moisture. A: ash yield. V: volatile matter. $\mathrm{S}_{\mathrm{t}}$ : total sulfur. ad: air-dry basis. d: dry basis. daf: dry and ash-free basis. $R_{o, \text { ran}}$ : random vitrinite reflectance. ${ }^{*}$, total thickness. 


\subsection{Minerals in Coal Samples}

The quantitative mineralogical contents determined by XRD and Siroquant for each coal-LTA and non-coal sample from the Bole and Laibin coal seams, as well as the LTA yields of the coals, are listed in Table 2.

Table 2. Low-temperature ash (LTA) yields of coal samples and mineral contents in coal LTAs, partings, and roof and floor strata samples determined by X-ray diffraction (XRD) and Siroquant (\%, on organic matter-free basis).

\begin{tabular}{|c|c|c|c|c|c|c|c|c|c|c|c|c|}
\hline Sample & LTA & Quartz & Kaolinite & $\mathrm{B} / \mathrm{C}^{*}$ & $\mathrm{I} / \mathrm{S}$ & Montmorillonite & Calcite & Anatase & Pyrite & Bassanite & Gypsum & Siderite \\
\hline B1-r & - & 10.9 & 34.8 & 15.8 & 32.3 & - & 2.5 & 3.7 & - & - & - & - \\
\hline B1-1 & 67.79 & 36.6 & 13.1 & 13 & 35.3 & - & 1.5 & 0.5 & - & - & - & - \\
\hline B1-2 & 44.79 & 53.6 & 5.0 & 21.6 & 0.8 & - & 19.1 & - & - & - & - & - \\
\hline B1-3p & - & 2.4 & 46 & & 43.5 & - & & 0.8 & 7.2 & - & - & - \\
\hline B1-4 & 32.20 & 52.2 & 8.8 & 31.4 & 0.7 & - & 4.6 & - & 2.3 & 0.1 & - & - \\
\hline B1-5 & 36.20 & 52.0 & 6.7 & 31.4 & 5.9 & - & 1.6 & - & 1.5 & 0.9 & - & - \\
\hline B1-6 & 35.85 & 35.1 & 8.8 & 27.9 & - & - & 27.0 & - & 1.3 & - & - & - \\
\hline B1-7 & 30.29 & 66.6 & 6.8 & 19.3 & - & - & 6.4 & - & 0.8 & - & - & - \\
\hline B1-8 & 54.00 & 75.2 & 5.5 & 15.1 & - & - & 3.6 & - & 0.6 & - & - & - \\
\hline B1-9 & 24.37 & 53 & 14.3 & 22.9 & - & - & 8.1 & - & 1.6 & - & - & - \\
\hline B1-f & - & 11.6 & 49.4 & - & 30.1 & - & - & 9.0 & - & - & - & - \\
\hline B2-1r & - & 28.1 & 16.4 & 13.8 & 38.6 & - & - & 3.1 & - & - & - & - \\
\hline B2-2r & - & 14.4 & 45.6 & - & 38.8 & - & 1.2 & - & - & - & - & - \\
\hline B2-3r & - & 23.2 & 10.0 & 51.4 & 13.1 & - & - & 2.2 & - & - & - & - \\
\hline B2-1 & 65.96 & 41.3 & 21.8 & 30.2 & 5.2 & - & 1.3 & - & 0.3 & - & - & - \\
\hline B2-2 & 79.87 & 25.7 & 55.5 & 8.7 & 8.8 & - & 0.9 & - & 0.3 & - & - & - \\
\hline B2-3 & 30.04 & 52.8 & 4.6 & 32.9 & - & - & 8.8 & - & 1.0 & - & - & - \\
\hline B2-4 & 27.11 & 58.7 & 9.6 & 24.2 & - & - & 6.8 & - & 0.8 & - & - & - \\
\hline B2-5 & 35.06 & 40.2 & 7.3 & 33.6 & 2.9 & - & 14.3 & 0.9 & 0.7 & - & - & - \\
\hline$B 2-f$ & - & 16.4 & 50.6 & - & 27.3 & - & - & 5.7 & - & - & - & - \\
\hline B3-r & - & 10.7 & 30.8 & 14.1 & 35.1 & - & 1.0 & 6.7 & 1.5 & - & - & - \\
\hline B3-1 & 49.66 & 52.2 & 8.2 & 33.6 & - & - & 4.8 & - & 1.0 & 0.2 & - & - \\
\hline B3-2 & 32.21 & 45.5 & 9.8 & 32.4 & - & - & 9.7 & - & 1.5 & 1.1 & - & - \\
\hline B3-3 & 31.39 & 53.2 & 9.6 & 28.4 & - & - & 6.9 & - & 1.0 & 1.0 & - & - \\
\hline B3-4 & 24.83 & 20.7 & 7.1 & 41.6 & - & - & 24.7 & - & 1.9 & 3.9 & - & - \\
\hline B3-5p & - & 5.8 & 82.0 & - & - & - & 5.3 & - & 3.0 & - & 3.9 & - \\
\hline B3-6 & 26.55 & 45.4 & 10.8 & 33.1 & - & - & 7.9 & - & 1.5 & 1.3 & - & - \\
\hline B3-7 & 33.41 & 54.2 & 6.3 & 21.8 & - & - & 16.9 & - & 0.7 & - & - & - \\
\hline B3-f & - & 11.6 & 50.3 & & 30.4 & - & 0.6 & 7.1 & & - & - & - \\
\hline C1-1r & - & 2.9 & 80.4 & 8.4 & - & - & - & 7.8 & 0.6 & - & - & - \\
\hline C1-2r & - & 72.8 & 10.0 & 15.1 & 1.5 & - & - & - & 0.6 & - & - & - \\
\hline C1-3r & - & 2.8 & 63.9 & - & - & 24.9 & 0.3 & 0.9 & 6.6 & - & - & 0.5 \\
\hline C1-4r & - & 4.8 & 82.8 & - & - & 8 & 1.6 & 1.0 & 1.8 & - & - & - \\
\hline C1-5r & - & 3.7 & 86.3 & - & - & 5.1 & 0.7 & 0.9 & 3.3 & - & - & - \\
\hline C1-6r & - & 3.4 & 60.4 & 26.5 & - & 1.4 & 0.6 & 6.8 & 0.8 & - & - & - \\
\hline C1-7r & - & 69.5 & 21.0 & 4.8 & 4.0 & - & 0.1 & 0.6 & 0.1 & - & - & - \\
\hline C1-1t & - & 2.5 & 91.2 & - & - & - & - & 1.0 & 5.3 & - & - & - \\
\hline C1-2 & 43.72 & 75.9 & 7.0 & 16.1 & - & - & 0.7 & - & 0.3 & - & - & - \\
\hline C1-3 & 23.24 & 68.0 & 8.2 & 17.7 & - & - & 2.0 & - & 3.7 & 0.4 & - & - \\
\hline C1-4 & 30.04 & 53.0 & 8.2 & 14.4 & - & - & 19.0 & - & 5.3 & - & - & - \\
\hline C1-5 & 17.51 & 28.4 & 17.2 & 27.6 & - & - & 23.0 & - & 3.9 & - & - & - \\
\hline $\mathrm{C} 1-6$ & 30.14 & 65.9 & 20.6 & 7.9 & - & - & 4.5 & - & 0.7 & 0.3 & - & - \\
\hline C1-7 & 12.39 & 22.7 & 39.7 & 20.8 & - & - & 12.5 & - & 4.3 & - & - & - \\
\hline$C 1-8 p$ & - & 7.1 & 89.6 & - & 2.7 & - & - & - & 0.6 & - & - & - \\
\hline C1-9 & 38.24 & 29.3 & 45.5 & 17.9 & - & - & 2.3 & 2.0 & - & 0.5 & - & - \\
\hline $\mathrm{C} 1-10$ & 48.66 & 55.0 & 39.1 & 4.9 & 0.1 & - & 0.4 & 0.6 & - & - & - & - \\
\hline C1-11 & 20.47 & 34.9 & 19.7 & 29.1 & - & - & 14.6 & - & 1.6 & - & - & - \\
\hline C1-12 & 25.21 & 61.2 & 15.2 & 19.3 & - & - & 2.3 & - & 1.7 & 0.3 & - & - \\
\hline $\mathrm{C} 1-13$ & 47.34 & 46.1 & 14.2 & 24.3 & 12.1 & - & 1.2 & - & 2.2 & - & - & - \\
\hline C1-14 & 80.90 & 13.5 & 68.0 & - & 15.9 & - & - & 2.0 & 0.6 & - & - & - \\
\hline $\mathrm{C} 1-1 \mathrm{f}$ & - & 4.7 & 80.2 & - & 10.1 & - & 1.1 & 3.9 & - & - & - & - \\
\hline C1-2f & - & 4.3 & 84.4 & - & 1.0 & - & 0.4 & 9.9 & - & - & - & - \\
\hline
\end{tabular}

* Proportions of berthierine + chamosite. B/C: interstratified berthierine/chamosite. I/S: mixed layer illite/smectite.

The mineral assemblages in the coal LTAs from Bole and Laibin mines are similar. The dominant mineral phases identified are clay minerals and quartz, while calcite and pyrite were detected as minor components in most of the coal LTAs. 


\subsubsection{Clay Minerals}

The clay minerals identified in the LTAs of the coal samples by powder-XRD and the clay-fraction studies are interstratified berthierine/chamosite (B/C) and kaolinite with small proportions of mixed-layer illite/smectite (I/S).

Berthierine (serpentine group) and chamosite (chlorite group), which are both Fe-rich clay minerals, have a similar chemical composition to dominant $\mathrm{Si}, \mathrm{Al}$, and $\mathrm{Fe}$, and a small amount of $\mathrm{Mg}$ [31,59-61], and can only be distinguished using X-ray diffraction analysis to identify the $14 \AA$ reflection occurring in chamosite but absent in berthierine.

The XRD patterns of the LTAs of the coals and their air-dried oriented aggregates show a 001 reflection at $14.1 \AA$ (Figures $3 \mathrm{~A}$ and $4 \mathrm{~A}$ ), confirming the presence of a chamosite component. However, unlike a pure chamosite, the $7 \AA$ peak of the studied samples is sharp and narrow, whereas the $14 \AA$ reflection is diffuse and broad (Figure $3 \mathrm{~A}$ ), and this is regarded as being characteristic of randomly interstratified $14 \AA$ (chlorite) and $7 \AA$ (berthierine) layers [62-67]. Because of the interstratification, the 001 reflections are much weaker than that of a pure chamosite or are even absent in some coal LTA samples (Figures 3B and 4B). Brindley [59] proposed that berthierine with a small admixture of Fe-rich chlorite may easily be mistaken as a pure chamosite, while no $14 \AA$ A peak appears in the XRD pattern. A small amount of chlorite layers (for example, 10\% or fewer) within the crystal can lead to failure in the correct identification of berthierine $[63,65,68]$. Therefore, the Fe-rich clay mineral in the coal LTA samples is referred to as interstratified B/C in this study (Table 2).

Quantitative XRD analysis indicates that B/C (along with kaolinite) is the dominant clay mineral in most Bole and Laibin coals (Table 2), rather than a pure Fe-rich chlorite (chamosite), as widely reported in other Late Permian coals from Southwestern China $[24,25,30]$. Under the SEM, B/C usually occurs as cell-infillings along with quartz (Figure 5A-C) or fills in the cavities of quartz and calcite (Figure 5D), and, to a lesser extent, co-exists with kaolinite in the coal-forming plant-cells (Figures 5E and 6A,B), which are all indicative of an authigenic origin.
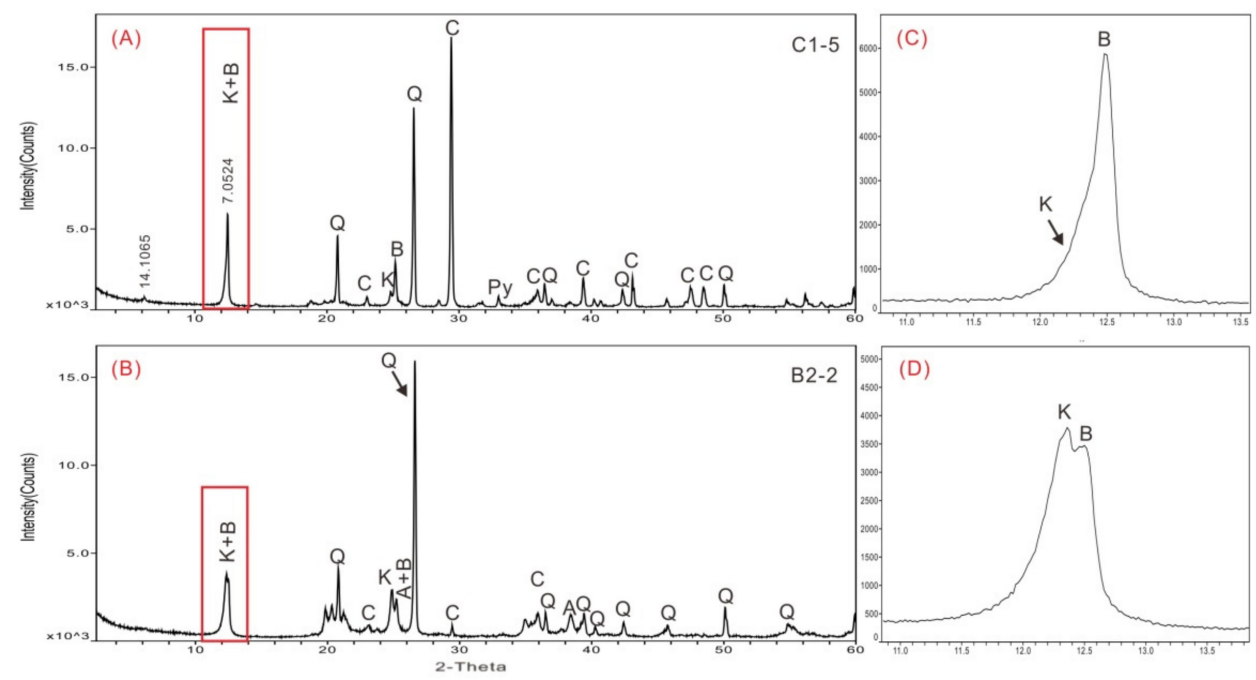

Figure 3. X-ray powder diffraction patterns of LTAs of coal samples C1-5 (A) and B2-2 (B). (C) and (D) are enlargement of the specific areas in (A) and (B), respectively. Q: quartz. B: berthierine. C: calcite. A: anatase. K: kaolinite. Py: pyrite. 

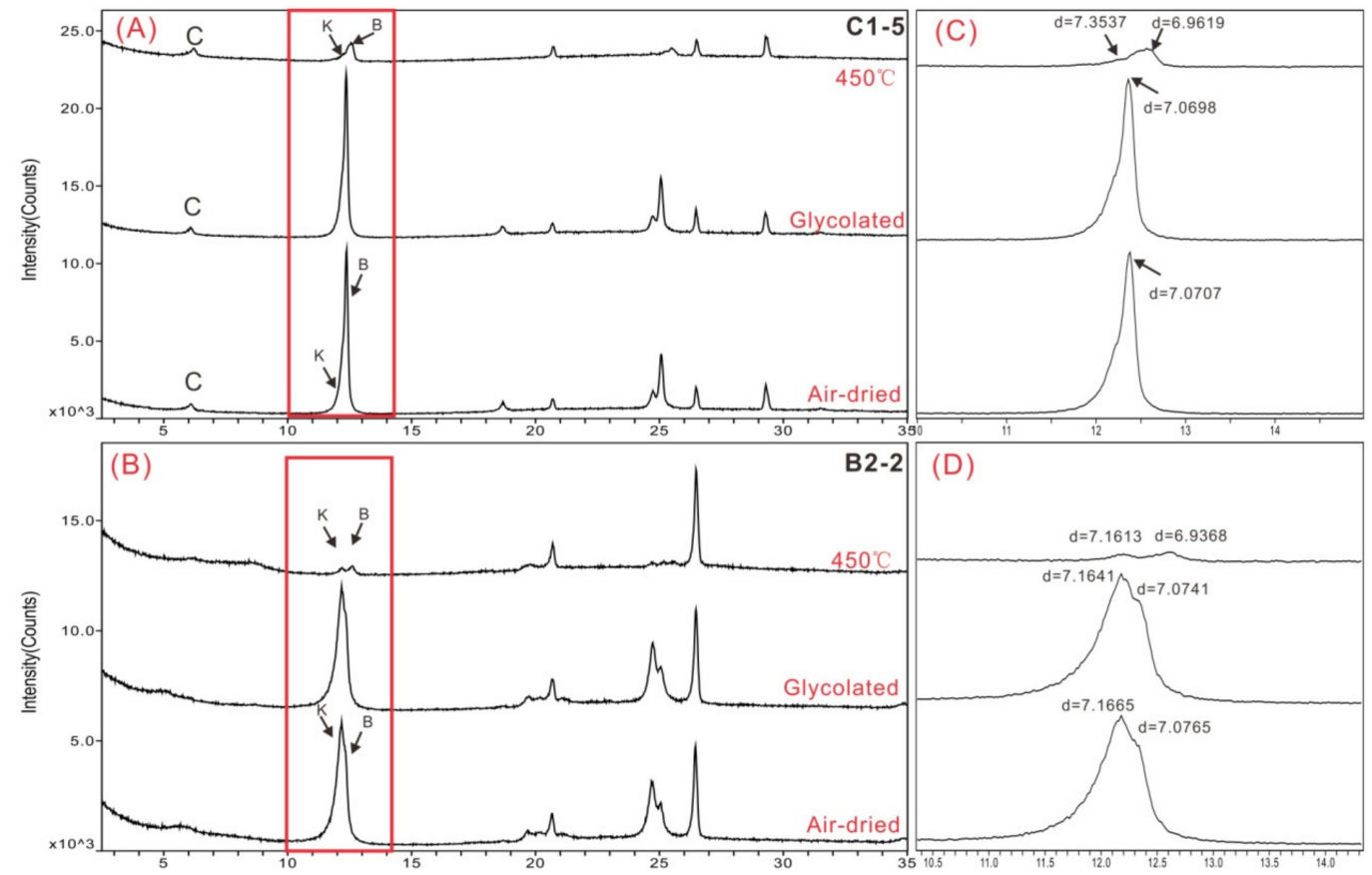

Figure 4. X-ray diffraction (XRD) patterns from air-dried, glycolated, and heated orientated sample of the $<2 \mu \mathrm{m}$ clayFigure 1. (A) and B2-2 (B). (C) and (D) are enlargement of the specific area in (A,B). K: kaolinite. B: berthierine. C: chamosite.

Kaolinite occurs in the coal LTAs in varying proportions (Table 2). There are some difficulties in the identification of kaolinite in some cases. The 001 peaks of both kaolinite and $\mathrm{B} / \mathrm{C}$ are around $7 \AA$, which are difficult to distinguish when the content of kaolinite is high (e.g., sample B2-2, Figure 3B,D). XRD analysis of the clay fractions $(<2 \mu \mathrm{m})$ prepared from the coal LTAs reveals that kaolinite and B/C show nearly one peak at $7.07 \AA$ for both air-dried and glycolated patterns, which is divided into two distinct peaks at $7.35 \AA$ and $6.96 \AA$ after $450{ }^{\circ} \mathrm{C}$ heating (Figure $4 \mathrm{C}$ ). Kaolinite occurs as lens-like or book-like forms (Figure $7 \mathrm{~A}, \mathrm{~B})$. Some are clearly pseudomorphs after primary minerals (e.g., feldspar) (Figure 7C) and it also occurs as cell-infillings intergrown with B/C (Figure 6A,B). The modes of occurrence of kaolinite indicate that it is largely authigenic rather than detrital materials of terrigenous origin. Various contents of mixed layer I/S are detected in the LTAs of nine coal samples by XRD (Table 2).

\subsubsection{Quartz}

The contents of quartz in the coal LTAs of the Bole and Laibin mines are $20.7-75.2 \%$ and $13.5-75.9 \%$, respectively (Table 2). Quartz in the coals has two major modes of occurrence, distributed in organic matter and as cell-infillings, with the latter indicating an authigenic origin. (1) Quartz distributed in organic matter shows a variable size range from $<1 \mu \mathrm{m}$ to $20 \mu \mathrm{m}$ (Figure 8A). Quartz with this mode of occurrence in some cases shows welldeveloped crystal shapes (Figure 8B,C), while others are oriented along the lamination planes (Figure 8D). (2) The cell-infilling quartz can occur independently (Figure 9A) or coexist with B/C, calcite, or pyrite (Figure 5B-E). Additionally, a small proportion of quartz occurs as large rounded particles $(>100 \mu \mathrm{m})$ in coal samples, indicating a detrital origin (Figure 8E). A few high-temperature quartz pseudomorphs including well-developed hexagonal bipyramids were observed in sample B3-1 (Figure 8F), which may indicate a pyroclastic origin. 

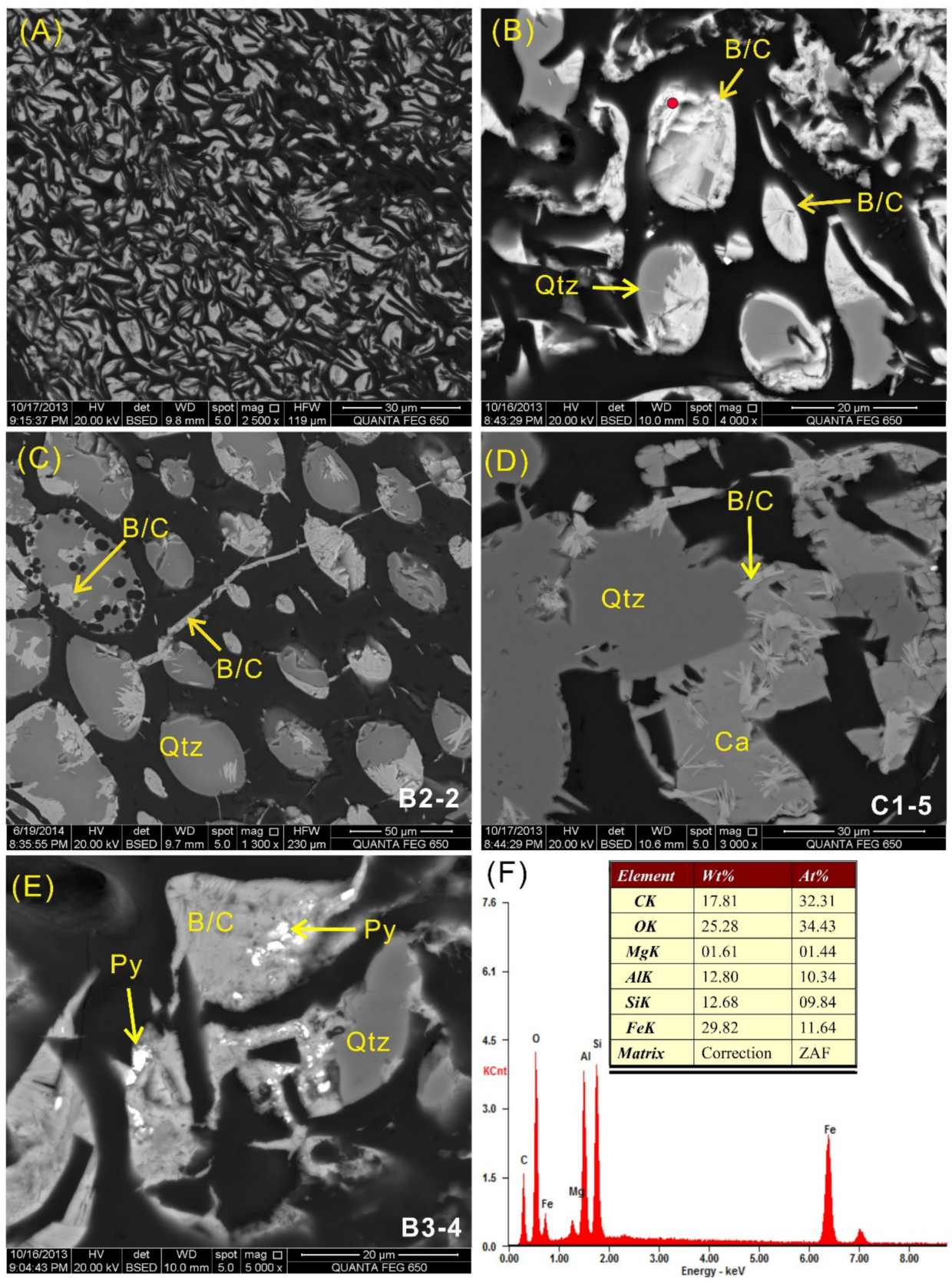

Figure 5. SEM back-scattered electron images of cell-filling minerals in coal samples and EDS data of a selected point. (A) Interstratified berthierine/chamosite as cell-infillings in sample C1-5. (B) Quartz coated with interstratified berthierine/chamosite as cell-infillings in sample B3-4. (C-E) Cell-filing interstratified berthierine/chamosite, quartz, calcite, and pyrite in samples B2-2 (C), sample C1-5 (D), and B3-4 (E). (F) EDS spectrum of point 1 in (B). Qtz: quartz. B/C: interstratified berthierine/chamosite. Py: pyrite. Ca: calcite. 

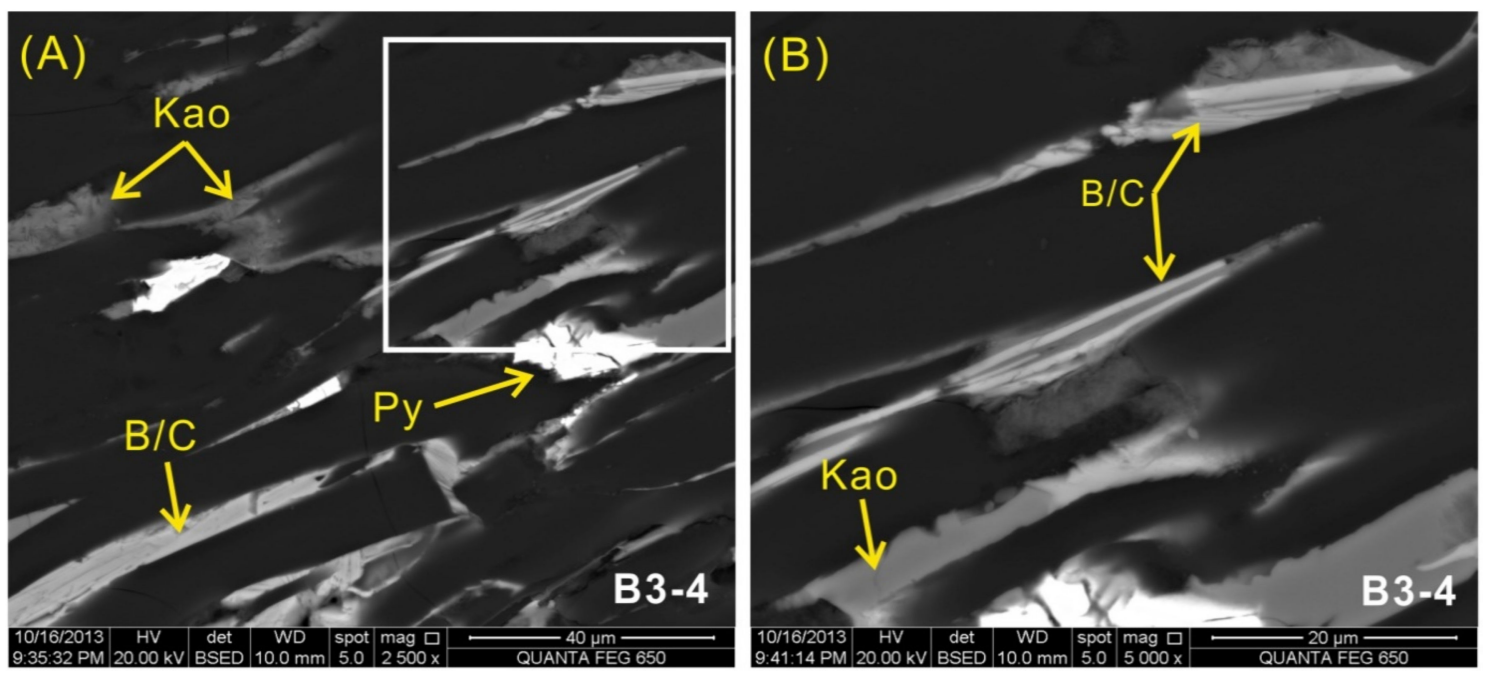

Figure 6. SEM back-scattered electron images of clay minerals in coal sample B3-4. (A) Cell-filling interstratified berthierine/chamosite, kaolinite, and pyrite. (B) Enlargement of rectangle in (A). B/C: interstratified berthierine/chamosite. Kao: kaolinite. Py: pyrite.
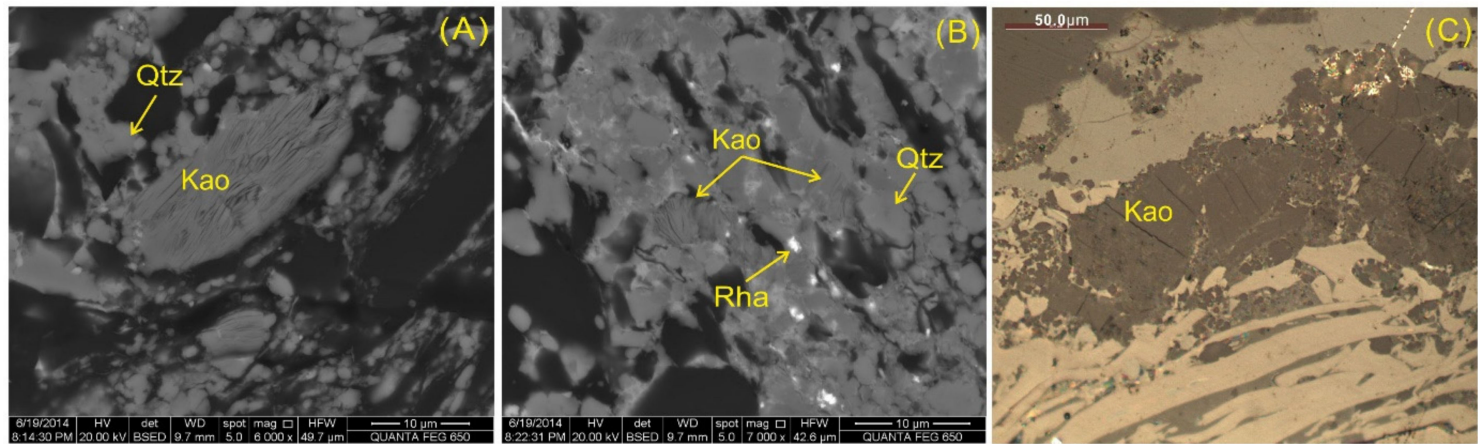

Figure 7. Kaolinite in sample B2-2. (A) Lump kaolinite and authigenic quartz. (B) Book-like kaolinite, quartz, and rhabdophane. (C) Kaolinite likely formed from in situ alteration of feldspar. (A,B) Back-scattered electron images. (C) Optical microscope, reflected light. Kao, kaolinite. Qtz: quartz. Rha: rhabdophane.

\subsubsection{Calcite}

Calcite is detected in all coal samples by XRD analysis. Its content varies greatly, ranging from $0.9 \%$ to $24.7 \%$ in the Laibin coals and from $0.4 \%$ to $23 \%$ in the Bole coals (Table 2). Calcite mostly occurs as cell-infillings (Figure 9A), or co-exists with quartz and berthierine (B/C) (Figure 5D), suggesting an authigenic origin. Fracture-infilling calcite is of epigenetic origin (Figure $9 \mathrm{~B}$ ).

\subsubsection{Pyrite}

With exceptions of samples C1-3 to C1-7 appearing to be unusual in containing more pyrite, the proportion of pyrite in the Bole and Laibin coals is low or below the detection limit of the XRD and Siroquant technique (Table 2). Various modes of occurrence of pyrite have been observed in the coal samples. Framboidal pyrite in collodetrinite is present and distributed along the lamination planes (Figure 8D). It was also observed as cell-infillings (Figures 5E and 6A), especially in the Laibin coals (e.g., B3-1), in which pyrite occurs in the cells as discrete euhedral crystals and was partly oxidized to an iron-sulphate mineral (Figure 10A,B). The modes of occurrence of pyrite indicate that it likely formed during the syngenetic or early diagenetic stage. In addition, epigenetic pyrite was also observed to fill in spaces between the euhedral quartz grains (Figure 8A,F). 

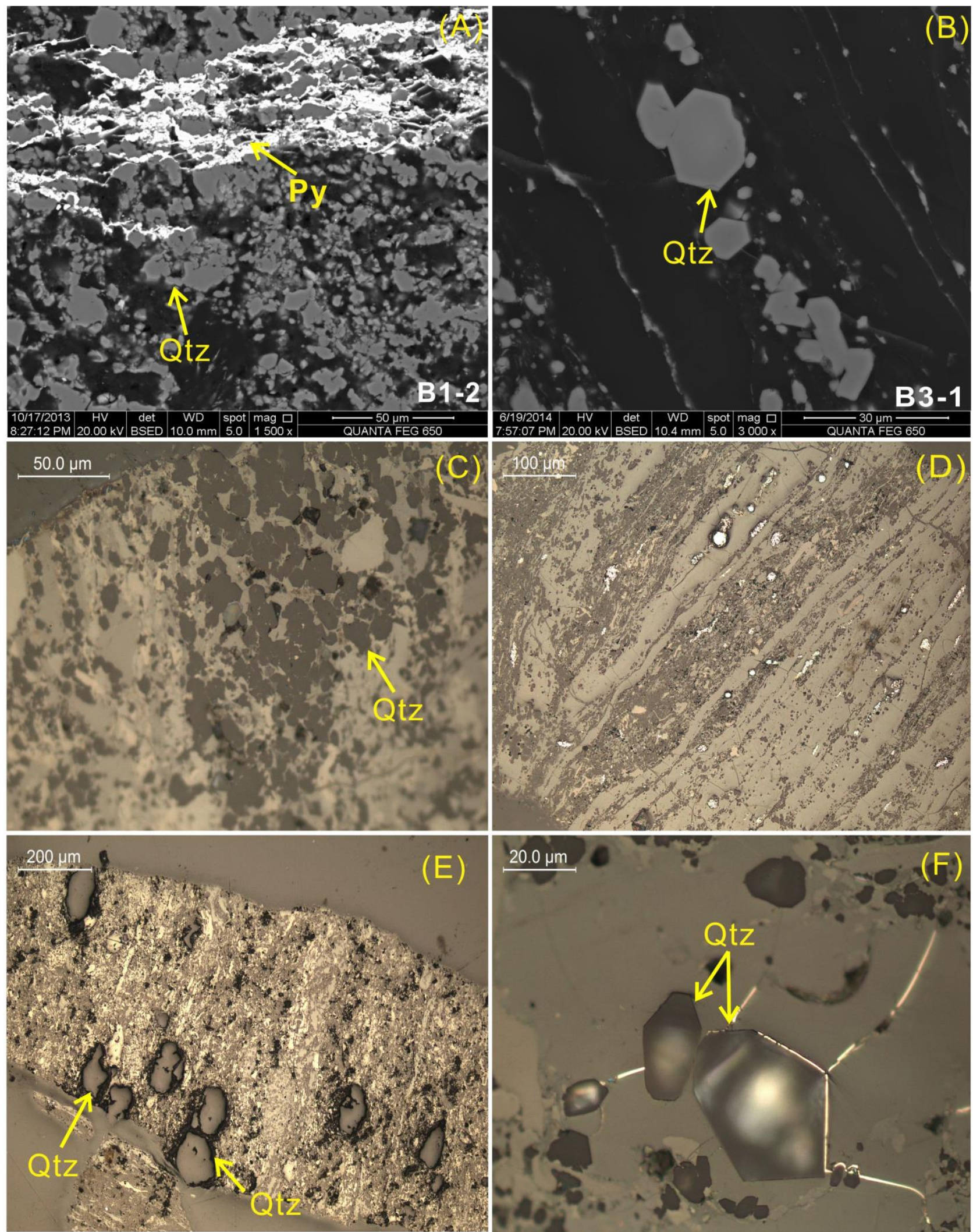

Figure 8. Quartz in the coal samples. (A) Authigenic quartz and fracture-filling pyrite in sample B1-2. (B,C) Fine-grained quartz in collodetrinite in sample B3-1. (D) Small quartz particles and framboidal pyrite along the lamination planes in sample B1-1. (E) Detrital quartz in sample B2-1. (F) Hexagonal bipyramid quartz rimmed by epigenetic pyrite in sample B3-1. (A,B), Back-scattered electron images. (C-F), Optical microscope, reflected light in air. Qtz: quartz. Py: pyrite. 

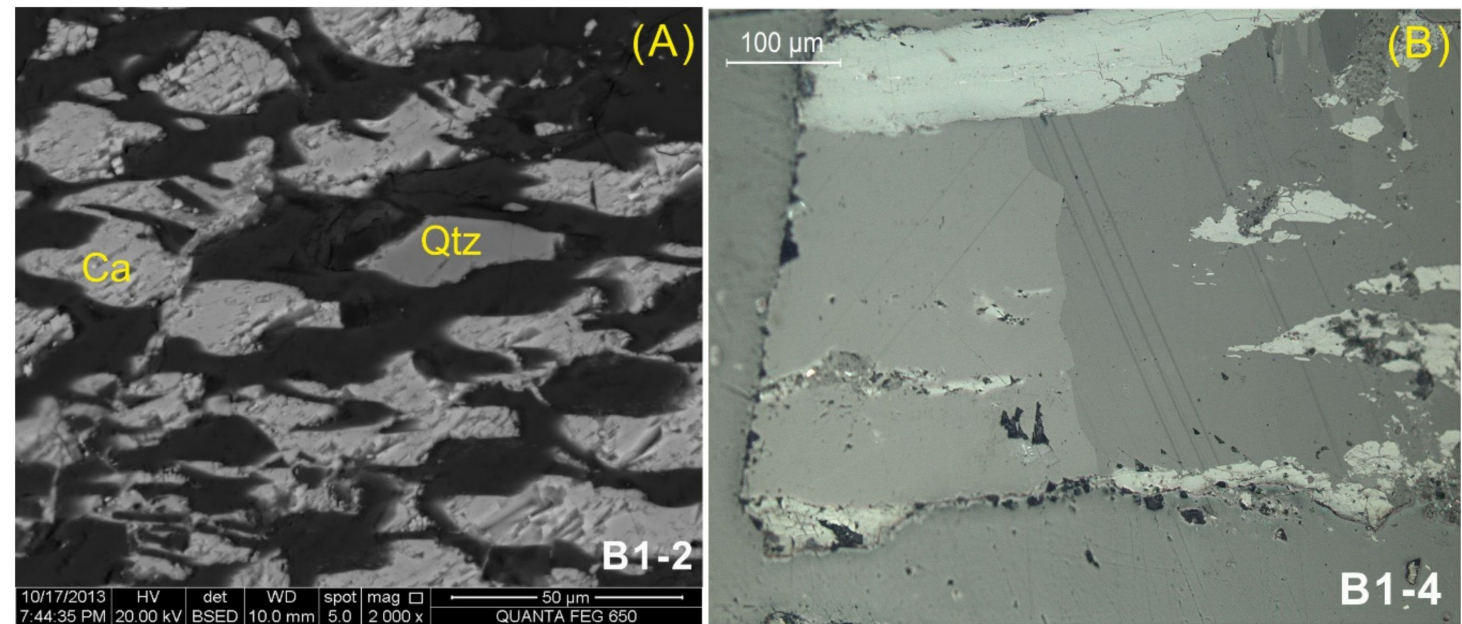

Figure 9. Calcite in the coal samples. (A) Cell-filling calcite and quartz in sample B1-2, back-scattered electron image. (B) Fracture-filling calcite in sample B1-4, optical microscope, reflected light. Qtz: quartz. Ca: calcite.
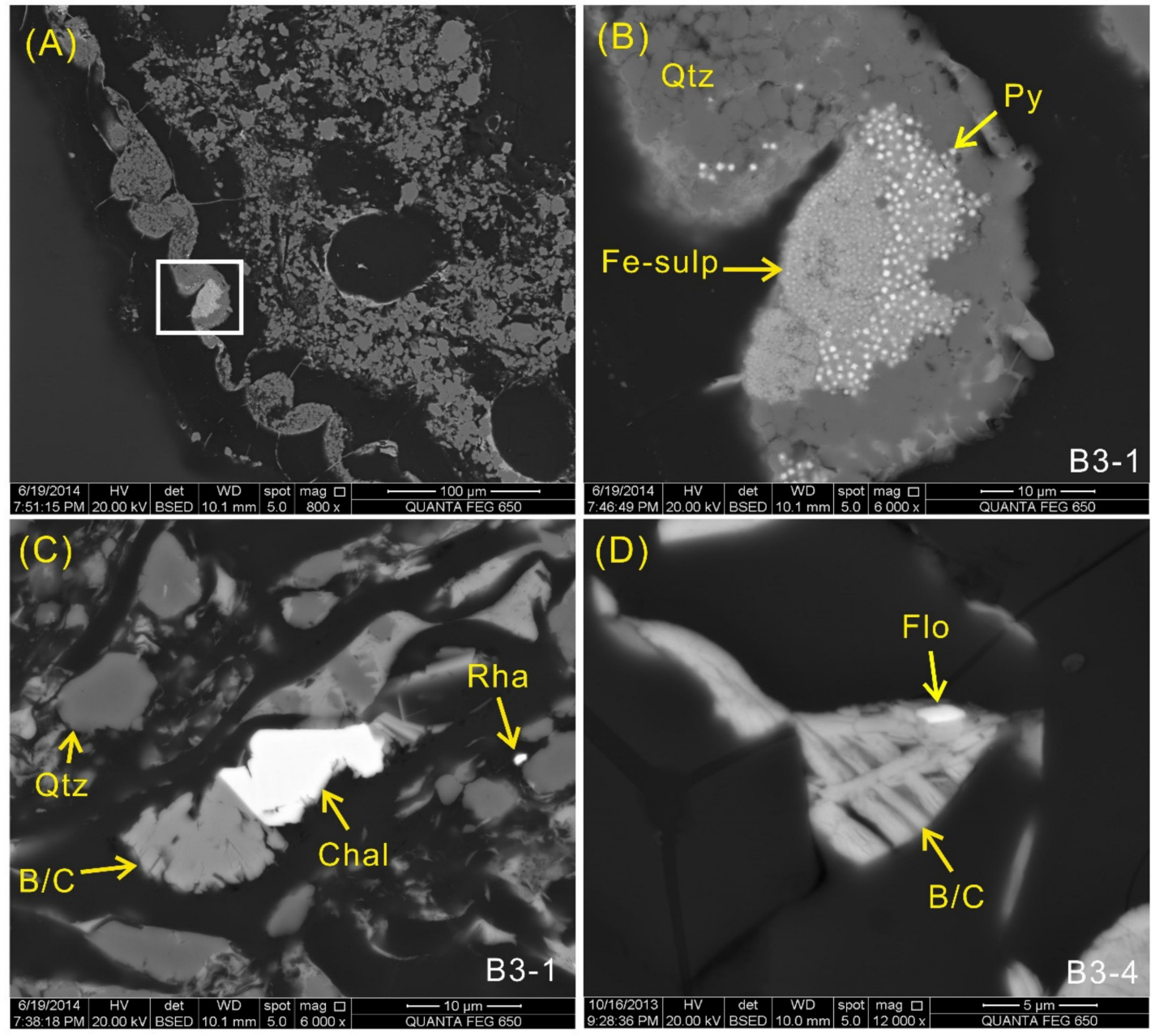

Figure 10. SEM back-scattered electron images of minerals in coal samples. (A) Cell-filling pyrite, iron-sulphate mineral, and quartz in sample B3-1. (B) Enlargement of rectangle in (A). (C) Rhabdophane and cell-filling chalcopyrite, quartz, and interstratified berthierine/chamosite in sample B3-1. (D) Cell-filling florencite and interstratified berthierine/chamosite in sample B3-4. B/C: interstratified berthierine/chamosite. Qtz: quartz. Py: pyrite. Fe-sulp: Fe-sulfate mineral. Rha: rhabdophane. Chal: chalcopyrite. Flo: florencite. B/C: interstratified berthierine/chamosite. 


\subsubsection{Other Minerals}

Other minerals identified in the coal samples include anatase, bassanite, chalcopyrite, and REE-phosphates (REE, rare earth elements). Anatase and bassanite are only present in trace proportions in a few coal LTAs (Table 2) and were not observed in un-ashed coal samples by SEM-EDS. Bassanite is usually considered an artefact of low-temperature ashing and produced by the interaction of inorganic calcium and organic sulfur in coal [69]. In addition, chalcopyrite and REE-phosphates (florencite and rhabdophane) are found under SEM-EDS even though they are below the detection limit of XRD and Siroquant. Chalcopyrite and florencite occur as cell-infillings (Figure 10C,D). Rhabdophane crystals are disseminated within kaolinite and authigenic quartz (Figures 7B and 10C).

\subsection{Minerals in Partings}

Table 2 shows that minerals in the four partings of the Bole and Laibin coals are mainly clays (kaolinite and mixed layer I/S) with a small amount of quartz and pyrite. The high content of kaolinite and low content of quartz in the partings are opposite to their proportions in the coal samples. The four partings, dominated by kaolinite, are identified as tonsteins formed from air-borne material of volcaniclastic origin. Their microscopic characteristics described below confirm this identification.

\subsubsection{Clay Minerals}

Kaolinite makes up $46.0-91.2 \%$ of the mineral assemblage of the four tonsteins, while mixed layer I/S are only detected in samples B1-3p (43.5\%) and C1-8p (2.7\%) (Table 2). The X-ray diffractograms indicate that the kaolinite is well-ordered. It mainly occurs as a cryptocrystalline matrix in samples B1-3p, C1-1t, and C1-8p, with no internal lamination and bedding (Figure 11A-C). Kaolinite is observed as elongated pellets in sample B3-5p (Figure 11D,E), which is considered to be characteristic of a "Graupen-tonstein" [1,18,70,71]. Phaneritic kaolinite grains are present in the vermicular (Figure 11A,E) and tabular (Figure 11C) forms. In some cases, kaolinite occurs as pseudomorphs after mica (most likely biotite, Figure $11 \mathrm{~F}$ ) and is intergrown with chlorite laminae, suggesting that both kaolinization and chloritization resulted from the alteration of biotite.

Mixed layer I/S in sample B1-3p mostly occurs as a matrix component (Figure 11G). The EDS data show that the I/S typically contains K, rather than Na (Figure $11 \mathrm{H}$ ) as the predominant cation. The illite and I/S in tonsteins are reported to have resulted mainly from alteration of the parent volcanic ash or replacement of kaolinite at high diagenetic (coal rank) levels $[10,16,18,72]$. In other coal deposits, it is also possible that mixed layer I/S is an intermediate product of the smectite-to-illite conversion during burial diagenesis in the marine-influenced depositional environment of peat [73] during the late Permian as reported by Dai and Chou [30]. In this study, the K-rich I/S most likely formed due to the devitrification of volcanic glass, with $\mathrm{K}^{+}$being derived from the break-down of $\mathrm{K}$-bearing minerals (e.g., biotite) [17] based on the sedimentary environment of formation and rank of the studied coals.

\subsubsection{Quartz}

A small proportion of quartz (2.4-7.1\%) is present in all the tonstein samples but is much lower than that in its host coal seams (Table 2). Quartz is mostly present as angular fragments or elongated particles (Figure 12A,B) within the kaolinite matrix. The angular quartz grains are especially abundant in sample C1-8p (Figure 12C). Corroded quartz with jagged edges or cavities was also found in sample C1-1t (Figures 11B and 12D). The modes of occurrence mentioned above are rarely detected in typical water-borne sedimentary detritus, indicating a volcanic origin of the quartz. In sample B3-5p, detrital quartz occurs in subangular or sub-rounded forms (Figure 11D), some of which have serrated edges, most likely resulting from magmatic corrosion. 


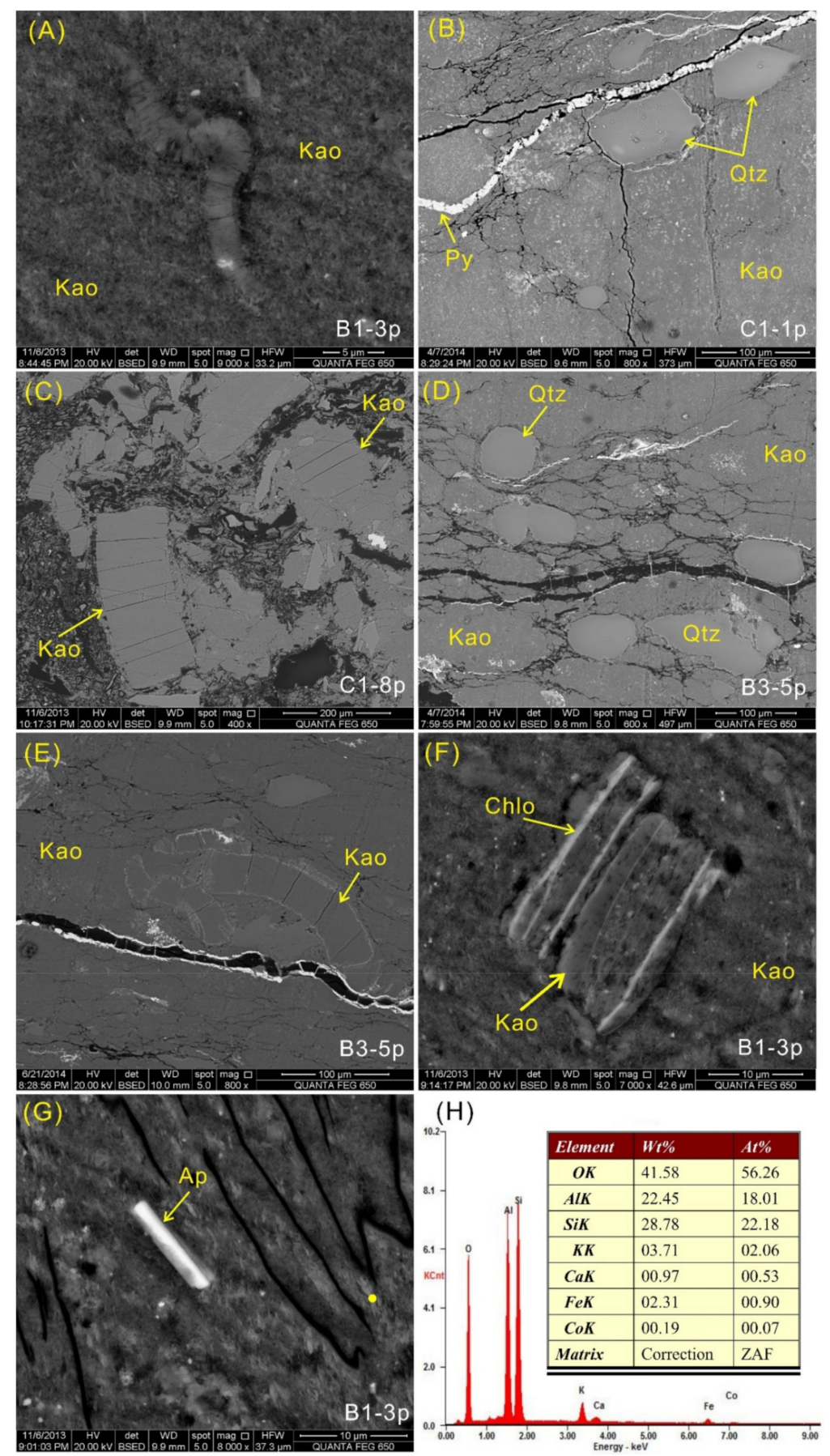

Figure 11. SEM back-scattered electron images of clay minerals in tonsteins and EDS data of selected point. (A) Vermicular kaolinite in sample B1-3p. (B) Cryptocrystalline kaolinite with quartz and pyrite in sample C1-1t. (C) Tabular kaolinite in sample C1-8p, possibly a pseudomorph after biotite or muscovite. (D) Elongated pellets and quartz in sample B3-5p. (E) Graupen and vermicular kaolinite in sample B3-5p. (F) Chlorite intergrown with kaolinite in sample B1-3p. (G) Mixed layer I/S and apatite in sample B1-3p. (H) EDS spectrum of point in (G). Kao: kaolinite. Qtz: quartz. Py: pyrite. Ap: apatite. 

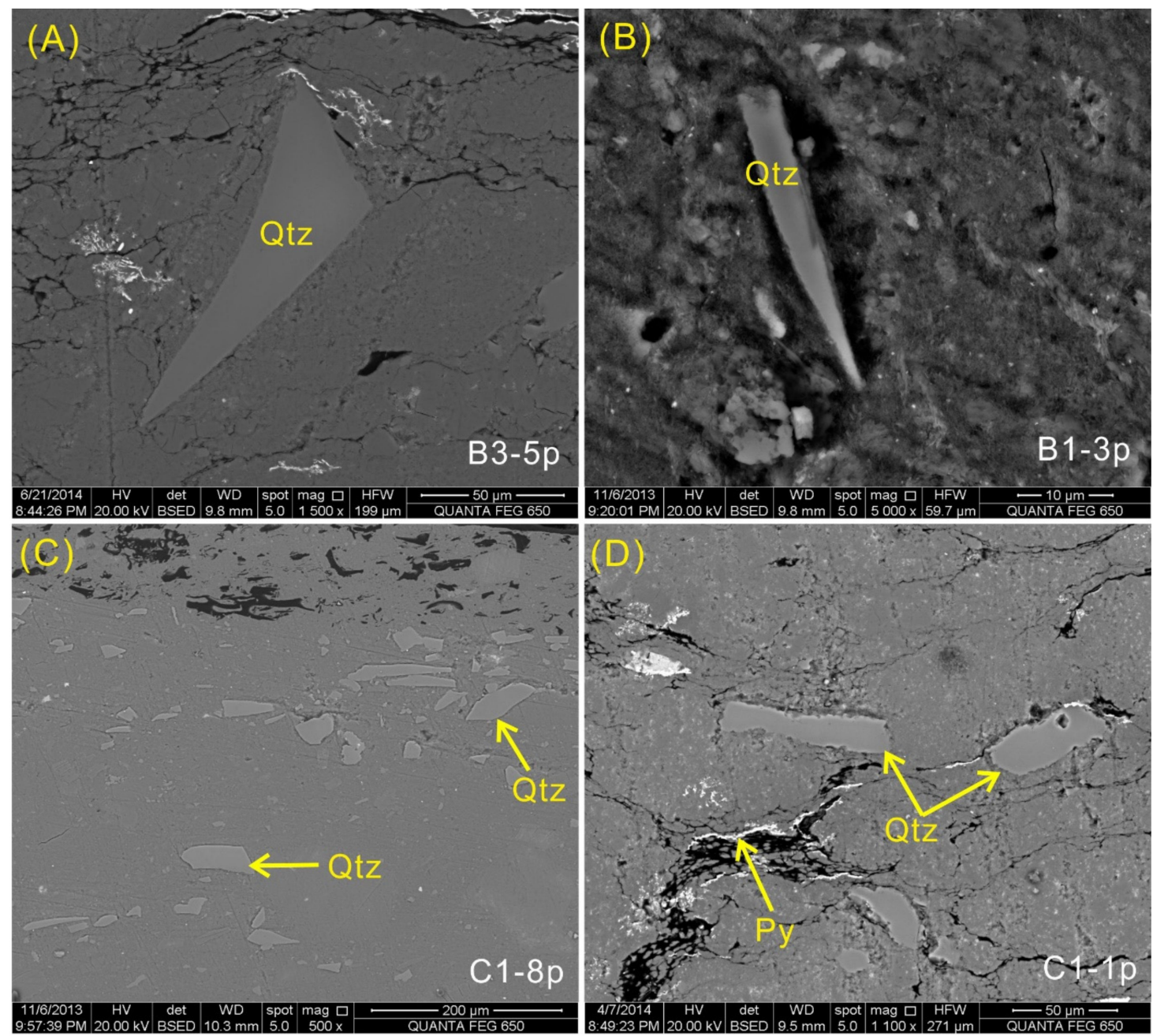

Figure 12. SEM back-scattered electron images of quartz in tonsteins. (A-C) Sharp-edged quartz in samples B3-5p, B1-3p, and C1-8p. (D) Corroded quartz and pyrite veinlets in C1-1t. Qtz: quartz. Py: pyrite.

\subsubsection{Other Minerals}

Under the SEM, accessory minerals observed in the four tonsteins are anatase, apatite, zircon, and monazite. Anatase is a minor constituent in the tonsteins and is only detected by XRD in samples B1-3p (0.8\%) and C1-1t (1\%) (Table 2). It forms discrete crystals with broken embayments (Figure 13A). In sample C1-1t, anatase likely replaces glass shards (Figure 13B,C). Such a phenomenon has been found in an Indonesian tonstein [74] and in coals associated with tonstein layers from the Songzao coalfield of Southwest China [71]. Anatase occurs as fracture-fillings (Figure 13D,E) in sample B3-5p, indicating an epigenetic hydrothermal origin. 

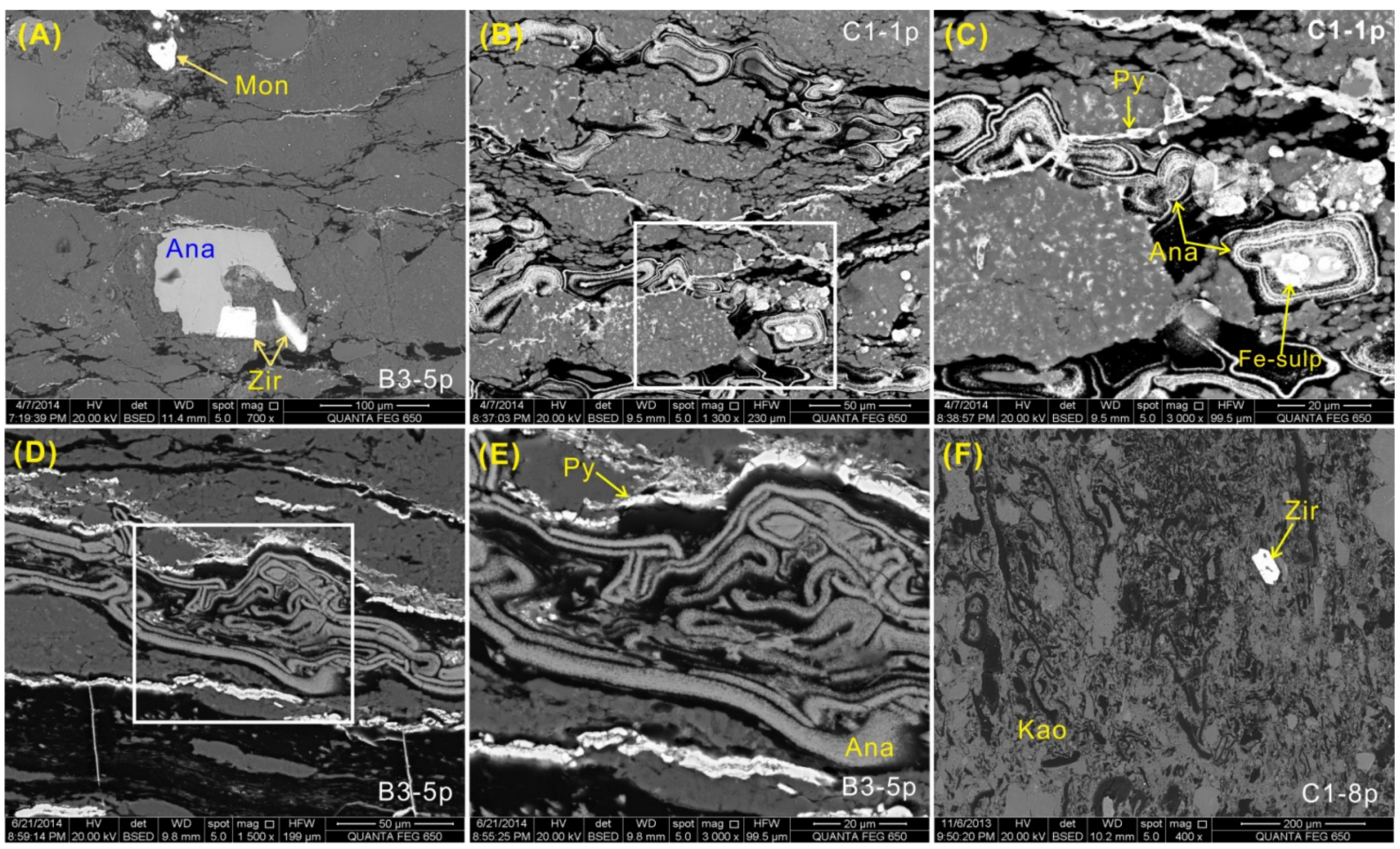

Figure 13. SEM back-scattered electron images of accessory minerals in tonsteins. (A) Anatase, zircon, and monazite in B3-5p. (B) Anatase possibly replacing glass spherules in C1-1t. (D) Fracture-filling anatase and pyrite in B3-5p. (C,E) are the enlargement of rectangles in (B,D). (F) Zircon in C1-8p. Mon: monazite. Ana: anatase. Zir: zircon. Fe-sulp: Fe-bearing sulfate mineral. Py: pyrite. Kao: kaolinite.

Zircon, apatite, and monazite mostly occur as disseminated, subhedral to euhedral grains within the kaolinite matrix. Zircon is found in samples B1-3p, B3-5p, and C1-8p in square or euhedral forms (Figures 13A,F and 14A). Some of the zircon grains have bubble cavities, indicating a volcanic origin. Apatite in sample B1-3p is frequently observed under the SEM. The euhedral apatite shows hexagonal, lath-like or bamboo-like forms distributed in the clay matrix (Figures $11 \mathrm{G}$ and $14 \mathrm{~A}-\mathrm{C}$ ). Some apatite crystals are subrounded in shape that may be due to magmatic corrosion or authigenic corrosion under acidic conditions of the peat swamp. Monazite is present only in sample B3-5p as discrete spherulites (Figures 13A and 14D), and this kind of REE-phosphate generally occurs in granites and rhyolites [75].

Other epigenetic minerals of the studied tonsteins include pyrite, gypsum, and an iron-sulphate mineral. Pyrite occurs as fracture-infillings (Figures 11B, 13B-E and 14E,F). The euhedral iron-sulphate aggregates in sample B3-5p (Figure 14E) may be an oxidation product of pyrite. Gypsum in sample B3-5p is detected with the percentage of 3.5\% by quantitative XRD analysis (Table 2), and found as euhedral phases, under the SEM (Figure 14F). This form of occurrence suggests that gypsum resulted from the reaction between calcite (or Ca leached from the nearby B3-4) and sulfuric acid produced by oxidation of pyrite [76,77]. 

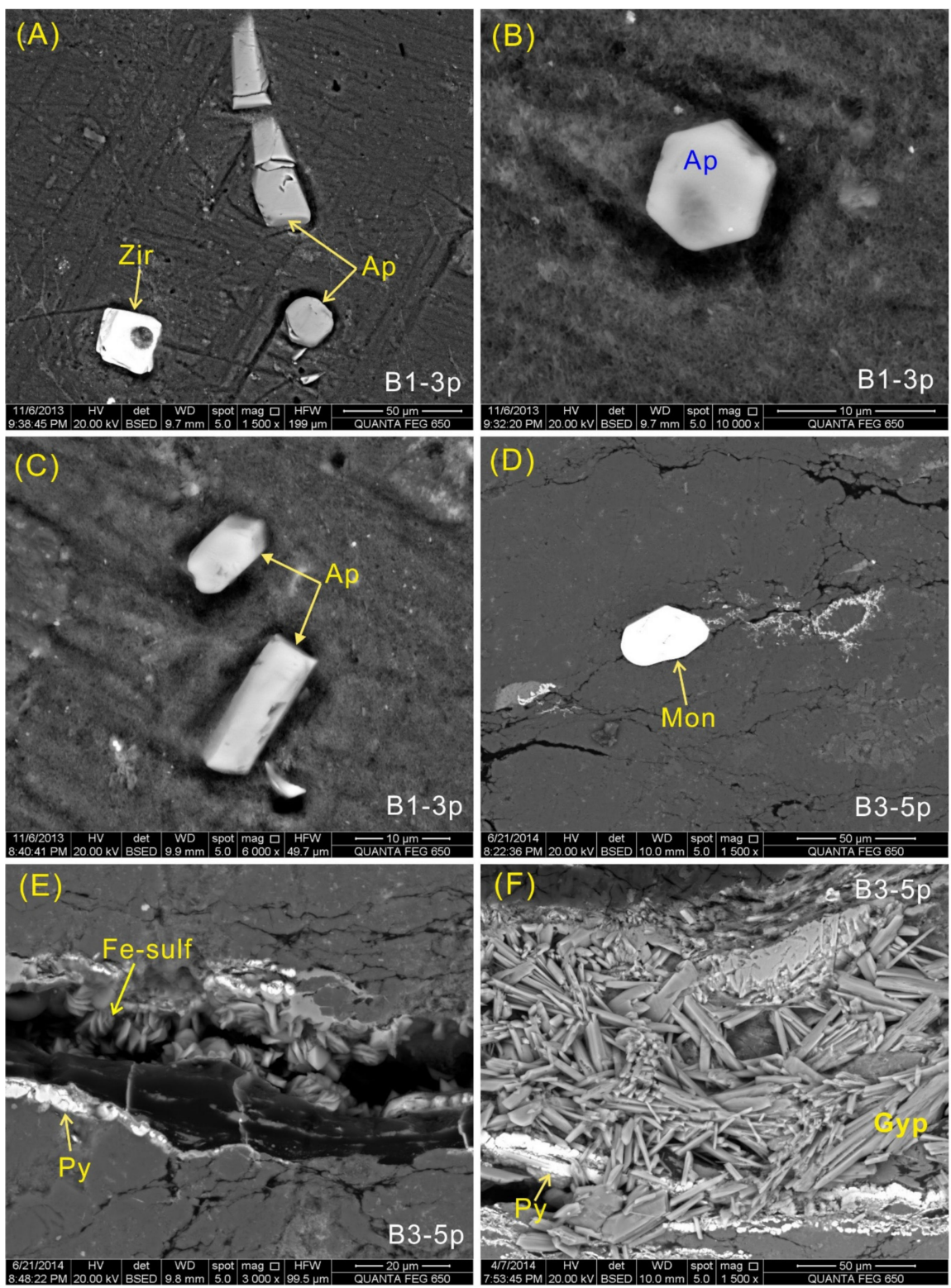

Figure 14. SEM back-scattered electron images of minerals in tonsteins. (A) Apatite and zircon in B1-3p. (B,C) Apatite crystals disseminated in the kaolinite matrix in B1-3p. (D) Monazite in B3-5p. (E) Fracture-filling pyrite and iron-sulfate mineral in B3-5p. (F) Euhedral gypsum in B3-5p. Zir: zircon. Ap: apatite. Mon: monazite. Py: pyrite. Gyp: gypsum.

\subsection{Minerals in the Roof and Floor Strata}

The mineral assemblages of the roof and floor strata samples in the Bole and Laibin mines are similar (Table 2). The roof and floor strata samples of the B1, B2, and B3 coal seams are mainly composed of kaolinite $(36.0 \%$ on average), mixed layer I/S (average $30.7 \%$ ) and quartz (average $15.9 \%$ ) with lesser percentages of anatase $(2.2-9 \%)$. B/C is also relatively abundant in the roof samples except for sample B2-2r. Trace proportions of calcite are present in several samples including B1-r, B2-2r, B3-r, and B3-f.

Almost all roof and floor samples of the $\mathrm{C} 1$ coal seam are represented by high kaolinite (60.4-84.4\%) and low quartz (2.8-13.5\%) contents with various proportions of smectite (or mixed-layer I/S), except for samples C1-2r and C1-7r, which have a low kaolinite and high quartz content, with small proportions of $\mathrm{B} / \mathrm{C}$ and mixed layer I/S. Calcite, anatase, and pyrite were detected as minor minerals in most of the roof and floor strata samples. 
Kaolinite and mixed layer I/S mainly occur as a matrix component with abundant disseminated plant residues, e.g., in sample B3-f of the Laibin mine (Figure 15A). Kaolinite can also occur in lump form (Figure 15B) or as cell-infillings with B/C (Figure 15C). In addition, vermicular B/C (Figure 15D), coarse-grained quartz (Figure 15B,D), and very small grains $(<1 \mu \mathrm{m})$ of disseminated rhabdophane (Figure $15 \mathrm{E})$ are distributed within the clay matrix, indicating an authigenic origin. There is also rhabdophane associated with B/C in a single particle (Figure 15F). These likely were crystallized from hydrothermal fluids with high REE concentrations. Highly altered anatase is represented by a network texture (Figure 15B), indicating a secondary origin. The uniform structure of clay-matrix without sedimentary layering and a large number of authigenic minerals generally observed in sample B3-f may be a consequence of humic-acid (from the peat) or hydrothermal leaching during diagenesis [78].
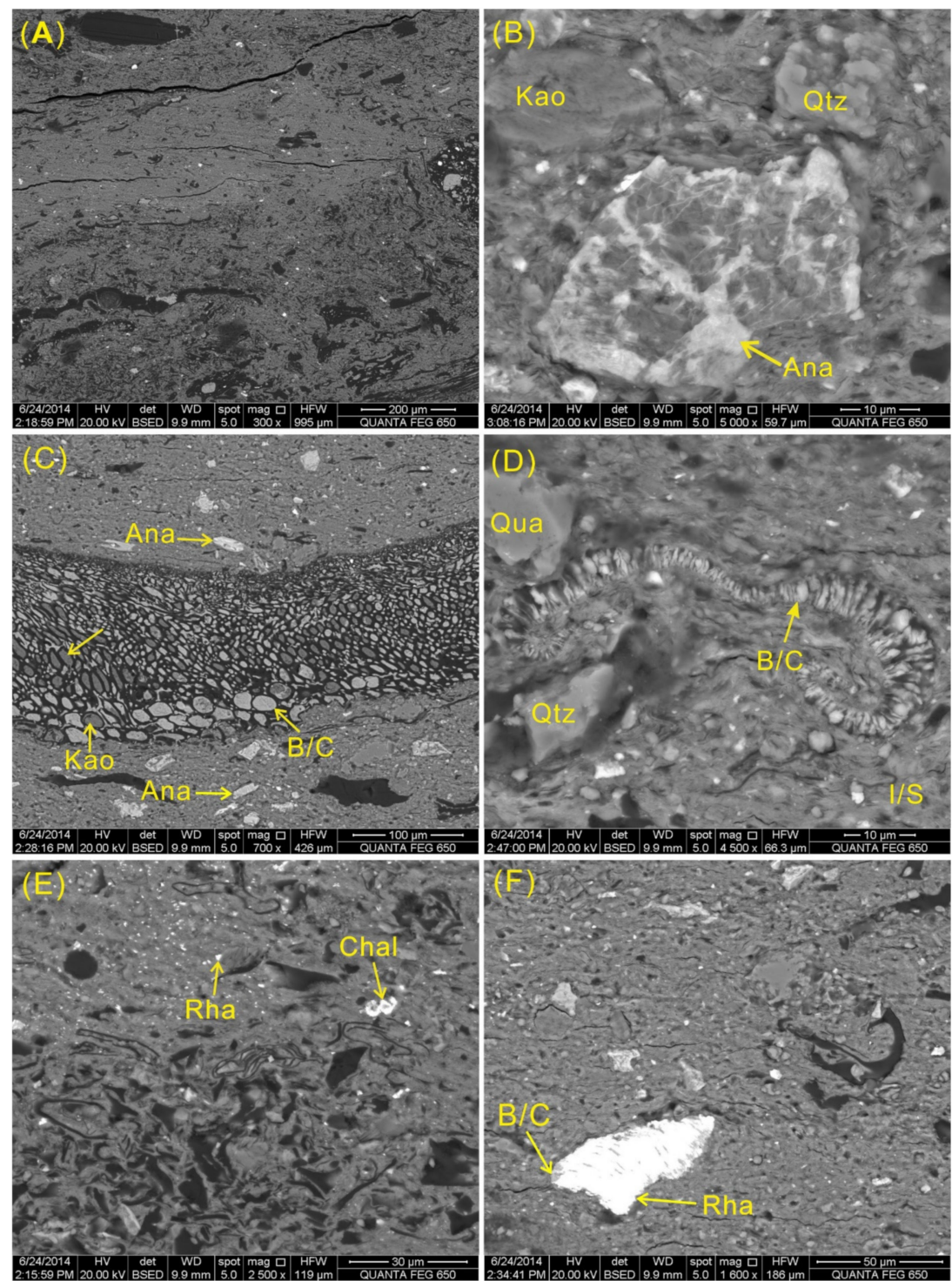

Figure 15. SEM back-scattered electron images of minerals in B3-f. (A) Clay minerals as matrix with abundant plant residues. (B) Kaolinite, authigenic quartz, and highly altered anatase with network texture. (C) Cell-filling kaolinite and B/C. (D) Vermicular B/C and authigenic quartz. (E) Small grains $(<1 \mu \mathrm{m})$ of rhabdophane. (F) Rhabdophane and associated B/C. B/C: interstratified berthierine/chamosite. Kao: kaolinite. Qtz: quartz. Ana: anatase. I/S: mixed layer illite/smectite. Chal: chalcopyrite. Rha: rhabdophane. 
In sample C1-2f from the Bole mine, the dominant kaolinite occurs as a microcrystalline matrix (Figure 16A). Discrete particles of anatase are frequently observed within the matrix (Figure 16A,B). In some cases, anatase was intensely altered and consequently resulted in the formation of a skeletal/colloidal structure (Figure 16C,D), while others have the original crystal outlines preserved (Figure 16E). Cracks or embayments in anatase (Figure 16F) may be caused by high-temperature volcanic processes rather than hydrothermal influence.
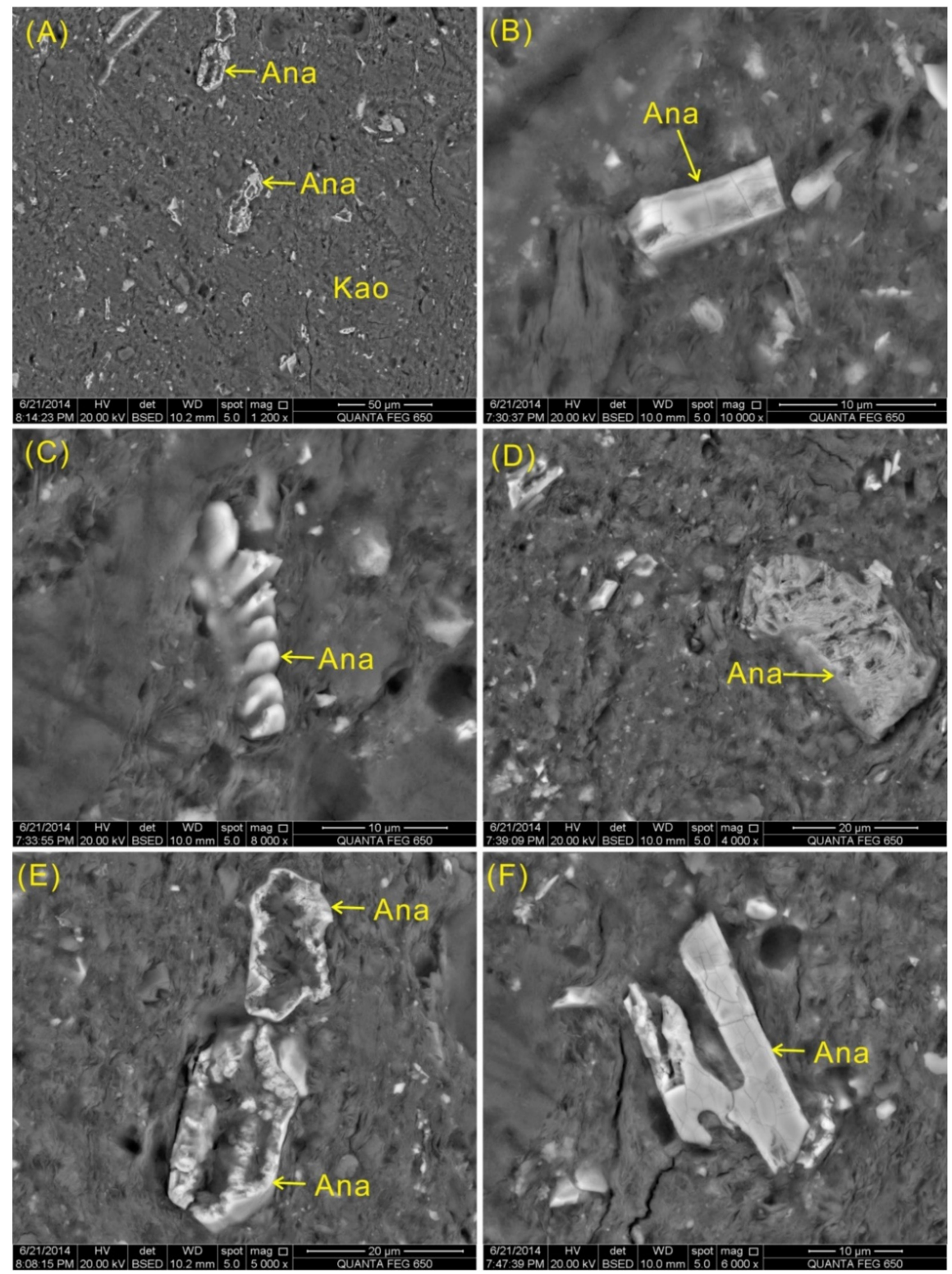

Figure 16. SEM back-scattered electron images of minerals in C1-2f. (A) Microcrystalline kaolinite matrix and anatase crystals. (B) Euhedral anatase crystal. (C-E) Altered anatase framework. (F) Anatase with high temperature cracks and embayments. Ana: anatase. Kao: kaolinite.

\subsection{Geochemistry}

\subsubsection{Major Element Oxides}

The percentages of major-element oxides in the Bole and Laibin coal samples are listed in Table 3. In comparison with the average values for Chinese coals reported by Dai et al. [5], both the Bole and Laibin coals contain higher proportions of $\mathrm{SiO}_{2}$ and $\mathrm{MnO}$, and $\mathrm{CaO}$ is slightly enriched in the Laibin coals. This is likely due to the high content of quartz and calcite since $\mathrm{MnO}$ in both the Bole and Laibin coal samples shows a strong correlation with $\mathrm{CaO}(r=0.95,0.99$, respectively). The percentages of the remaining major element 
oxides are close to or lower than the average values for Chinese coals, while $\mathrm{P}_{2} \mathrm{O}_{5}, \mathrm{~K}_{2} \mathrm{O}$, and $\mathrm{Na}_{2} \mathrm{O}$ are much less abundant. The $\mathrm{SiO}_{2} / \mathrm{Al}_{2} \mathrm{O}_{3}$ ratio is as high as $17.61 \mathrm{in} \mathrm{C} 1-2$ and 16.84 in B1-8 (Table 3), which is much higher than the average for Chinese coals (1.42) [5] and the theoretical value of kaolinite (1.18), reflecting a high quartz content in the coals (Table 2).

Table 3. Major-element oxides and loss on ignition of coal benches, roof, and floor strata samples, and partings from B1, B2, B3, and $\mathrm{C} 1$ coals. (\%, on whole coal/rock basis).

\begin{tabular}{|c|c|c|c|c|c|c|c|c|c|c|c|c|c|}
\hline Sample & LOI & $\mathrm{SiO}_{2}$ & $\mathrm{TiO}_{2}$ & $\mathrm{Al}_{2} \mathrm{O}_{3}$ & $\mathrm{Fe}_{2} \mathrm{O}_{3}$ & $\mathrm{MnO}$ & $\mathrm{MgO}$ & $\mathrm{CaO}$ & $\mathrm{Na}_{2} \mathrm{O}$ & $\mathrm{K}_{2} \mathrm{O}$ & $\mathrm{P}_{2} \mathrm{O}_{5}$ & $\mathrm{SiO}_{2} / \mathrm{Al}_{2} \mathrm{O}_{3}$ & $\mathrm{Al}_{2} \mathrm{O}_{3} / \mathrm{TiO}_{2}$ \\
\hline B1-r & 13.63 & 42.84 & 3.85 & 25.44 & 9.43 & 0.051 & 0.77 & 1.34 & bdl & 1.866 & 0.172 & 1.68 & 6.61 \\
\hline B1-1 & 40.73 & 39.32 & 0.51 & 12.28 & 3.68 & 0.025 & 0.32 & 0.72 & 0.321 & 1.624 & 0.022 & 3.20 & 24.1 \\
\hline B1-2 & 54.45 & 31.45 & 0.08 & 3.74 & 3.92 & 0.126 & 0.17 & 5.16 & bdl & 0.151 & 0.025 & 8.40 & 46.4 \\
\hline B1-3p & 17.07 & 43.19 & 0.57 & 31.02 & 4.34 & 0.013 & 0.38 & 0.98 & 0.134 & 1.808 & 0.129 & 1.39 & 54.8 \\
\hline B1-4 & 68.16 & 22.13 & 0.07 & 2.80 & 4.39 & 0.038 & 0.18 & 1.58 & bdl & 0.061 & 0.012 & 7.90 & 42.9 \\
\hline B1-5 & 65.30 & 24.70 & 0.13 & 3.28 & 5.41 & 0.017 & 0.24 & 0.49 & bdl & 0.076 & 0.007 & 7.53 & 24.5 \\
\hline B1-6 & 67.17 & 17.38 & 0.06 & 2.61 & 4.58 & 0.144 & 0.19 & 7.15 & bdl & 0.042 & 0.012 & 6.65 & 42.3 \\
\hline B1-7 & 70.15 & 23.15 & 0.13 & 2.15 & 2.25 & 0.030 & 0.09 & 1.56 & bdl & 0.053 & 0.006 & 10.79 & 17.1 \\
\hline B1-8 & 46.70 & 47.75 & 0.26 & 2.84 & 1.15 & 0.021 & 0.03 & 0.84 & bdl & 0.097 & 0.010 & 16.84 & 11.0 \\
\hline B1-9 & 76.21 & 15.22 & 0.12 & 2.86 & 3.14 & 0.031 & 0.13 & 1.60 & bdl & 0.035 & 0.011 & 5.33 & 23.4 \\
\hline B1-f & 13.30 & 46.54 & 5.32 & 26.02 & 5.71 & 0.016 & 0.71 & 0.68 & 0.056 & 1.058 & 0.055 & 1.79 & 4.89 \\
\hline WA-B1 & 62.79 & 26.15 & 0.17 & 3.98 & 3.40 & 0.054 & 0.16 & 2.44 & 0.180 & 0.257 & 0.013 & 8.04 & 14.0 \\
\hline B2-1r & 11.02 & 57.39 & 1.50 & 21.00 & 4.93 & 0.013 & 0.80 & 0.73 & 0.113 & 2.073 & 0.104 & 2.73 & 166 \\
\hline B2-2r & 11.35 & 52.49 & 0.18 & 30.45 & 1.57 & 0.029 & 0.38 & 1.12 & 0.121 & 1.897 & 0.046 & 1.72 & 11.9 \\
\hline B2-3r & 8.61 & 51.62 & 1.43 & 16.93 & 16.9 & 0.045 & 1.86 & 0.81 & bdl & 0.969 & 0.298 & 3.05 & 27.2 \\
\hline B2-1 & 31.39 & 46.98 & 0.37 & 9.91 & 9.30 & 0.023 & 0.69 & 0.46 & bdl & 0.398 & 0.044 & 4.74 & 34.7 \\
\hline B2-2 & 31.40 & 42.17 & 0.55 & 19.09 & 5.16 & 0.014 & 0.39 & 0.46 & 0.061 & 0.368 & 0.273 & 2.21 & 31.9 \\
\hline B2-3 & 73.39 & 19.28 & 0.06 & 2.01 & 2.89 & 0.042 & 0.14 & 1.72 & bdl & 0.016 & 0.008 & 9.58 & 23.4 \\
\hline B2-4 & 73.60 & 19.64 & 0.11 & 2.55 & 2.38 & 0.028 & 0.11 & 1.12 & bdl & 0.066 & 0.007 & 7.71 & 13.7 \\
\hline B2-5 & 64.12 & 20.79 & 0.30 & 4.05 & 6.25 & 0.067 & 0.34 & 2.65 & bdl & 0.071 & 0.021 & 5.13 & 10.1 \\
\hline B2-f & 13.44 & 49.71 & 2.61 & 26.24 & 5.28 & 0.015 & 0.69 & 0.55 & 0.132 & 0.861 & 0.051 & 1.89 & 14.0 \\
\hline WA-B2 & 61.48 & 25.62 & 0.22 & 5.95 & 4.28 & 0.037 & 0.25 & 1.43 & 0.035 & 0.128 & 0.056 & 6.65 & 26.7 \\
\hline B3-r & 15.45 & 41.46 & 3.92 & 23.29 & 11.2 & 0.035 & 1.17 & 1.16 & bdl & 1.201 & 0.362 & 1.78 & 5.94 \\
\hline B3-1 & 59.29 & 27.89 & 0.34 & 3.79 & 5.54 & 0.036 & 0.29 & 1.76 & 0.166 & 0.134 & 0.014 & 7.35 & 11.3 \\
\hline B3-2 & 71.56 & 16.31 & 0.08 & 2.61 & 4.84 & 0.035 & 0.27 & 2.40 & bdl & 0.024 & 0.012 & 6.25 & 34.5 \\
\hline B3-3 & 72.82 & 17.95 & 0.10 & 2.33 & 3.52 & 0.024 & 0.18 & 1.98 & bdl & 0.029 & 0.004 & 7.69 & 22.3 \\
\hline B3-4 & 76.98 & 8.82 & 0.04 & 2.62 & 5.34 & 0.072 & 0.29 & 4.52 & bdl & 0.013 & 0.062 & 3.36 & 66.6 \\
\hline B3-5p & 21.75 & 38.92 & 0.38 & 29.98 & 3.35 & 0.029 & 0.12 & 4.08 & 0.106 & 0.048 & 0.035 & 1.30 & 79.7 \\
\hline B3-6 & 76.75 & 14.14 & 0.12 & 2.41 & 3.63 & 0.029 & 0.17 & 1.95 & bdl & 0.025 & 0.012 & 5.86 & 20.6 \\
\hline B3-7 & 65.69 & 22.59 & 0.06 & 2.26 & 3.33 & 0.086 & 0.17 & 5.05 & bdl & 0.038 & 0.019 & 10.01 & 36.8 \\
\hline B3-f & 14.83 & 46.96 & 3.83 & 26.91 & 4.85 & 0.015 & 0.68 & 0.73 & 0.055 & 0.650 & 0.055 & 1.75 & 7.02 \\
\hline WA-B3 & 71.39 & 17.88 & 0.13 & 2.63 & 4.14 & 0.039 & 0.21 & 2.50 & 0.098 & 0.043 & 0.015 & 6.81 & 20.2 \\
\hline C1-1r & 14.56 & 39.66 & 5.29 & 28.47 & 9.58 & 0.024 & 0.52 & 0.73 & 0.091 & 0.337 & 0.296 & 1.39 & 5.38 \\
\hline C1-2r & 52.74 & 41.69 & 0.14 & 3.32 & 1.48 & 0.004 & 0.14 & bdl & bdl & 0.232 & 0.010 & 12.57 & 24.5 \\
\hline C1-3r & 20.07 & 42.93 & 0.55 & 31.41 & 3.35 & 0.009 & 0.19 & 0.90 & 0.128 & 0.086 & 0.083 & 1.37 & 57.5 \\
\hline $\mathrm{C} 1-4 \mathrm{r}$ & 24.54 & 39.70 & 0.61 & 29.29 & 2.91 & 0.010 & 0.16 & 0.69 & 0.071 & 0.084 & 0.113 & 1.36 & 48.3 \\
\hline C1-5r & 17.37 & 42.68 & 0.59 & 32.73 & 3.41 & 0.010 & 0.18 & 0.60 & 0.077 & 0.076 & 0.126 & 1.30 & 55.3 \\
\hline C1-6r & 9.99 & 39.16 & 5.89 & 25.19 & 15.9 & 0.036 & 1.03 & 1.22 & bdl & 0.478 & 0.445 & 1.55 & 4.28 \\
\hline C1-7r & 21.13 & 63.93 & 0.41 & 9.42 & 1.94 & 0.007 & 0.26 & 0.26 & 0.185 & 0.694 & 0.027 & 6.78 & 23.1 \\
\hline C1-1t & 19.95 & 42.33 & 0.65 & 33.56 & 2.73 & 0.005 & 0.08 & 0.24 & bdl & 0.079 & 0.091 & 1.26 & 51.6 \\
\hline C1-2 & 55.80 & 38.84 & 0.10 & 2.21 & 1.27 & 0.009 & 0.04 & 0.32 & bdl & 0.035 & 0.008 & 17.61 & 22.0 \\
\hline C1-3 & 74.69 & 21.02 & 0.07 & 1.68 & 1.45 & 0.016 & 0.03 & 0.67 & bdl & 0.030 & 0.008 & 12.50 & 22.7 \\
\hline C1-4 & 68.89 & 19.13 & 0.11 & 2.63 & 2.34 & 0.073 & 0.08 & 3.22 & 0.015 & 0.027 & 0.010 & 7.28 & 24.9 \\
\hline C1-5 & 81.05 & 8.82 & 0.05 & 2.20 & 2.91 & 0.088 & 0.10 & 3.55 & bdl & 0.006 & 0.005 & 4.01 & 41.0 \\
\hline C1-6 & 71.61 & 23.16 & 0.17 & 3.00 & 0.96 & 0.014 & 0.04 & 0.65 & bdl & 0.070 & 0.008 & 7.72 & 17.8 \\
\hline C1-7 & 88.47 & 5.34 & 0.07 & 2.29 & 1.87 & 0.034 & 0.07 & 1.43 & 0.008 & 0.011 & 0.011 & 2.33 & 35.0 \\
\hline$C 1-8 p$ & 24.76 & 40.49 & 0.16 & 29.07 & 3.12 & 0.007 & 0.20 & 0.29 & 0.104 & 0.093 & 0.032 & 1.39 & 179 \\
\hline C1-9 & 64.97 & 23.34 & 0.30 & 7.79 & 2.80 & 0.007 & 0.20 & 0.21 & 0.018 & 0.188 & 0.022 & 3.00 & 25.6 \\
\hline C1-10 & 64.63 & 28.54 & 0.23 & 5.35 & 0.67 & 0.008 & 0.05 & 0.27 & bdl & 0.074 & 0.018 & 5.34 & 23.3 \\
\hline C1-11 & 80.92 & 10.21 & 0.07 & 2.83 & 3.21 & 0.052 & 0.15 & 1.99 & bdl & 0.016 & 0.145 & 3.61 & 41.5 \\
\hline C1-12 & 76.94 & 17.33 & 0.09 & 2.52 & 2.15 & 0.014 & 0.08 & 0.53 & bdl & 0.029 & 0.015 & 6.88 & 29.1 \\
\hline C1-13 & 59.19 & 27.25 & 0.29 & 5.95 & 4.95 & 0.016 & 0.27 & 0.35 & bdl & 0.282 & 0.031 & 4.58 & 20.3 \\
\hline C1-14 & 37.55 & 35.40 & 1.80 & 19.73 & 3.85 & 0.008 & 0.39 & 0.38 & bdl & 0.408 & 0.079 & 1.79 & 10.9 \\
\hline C1-1f & 25.17 & 37.89 & 3.69 & 25.9 & 5.46 & 0.016 & 0.39 & 0.51 & bdl & 0.200 & 0.062 & 1.46 & 7.03 \\
\hline C1-2f & 14.57 & 42.40 & 6.13 & 28.35 & 6.48 & 0.030 & 0.51 & 0.62 & 0.060 & 0.297 & 0.072 & 1.50 & 4.62 \\
\hline WA-C1 & 72.31 & 18.89 & 0.20 & 4.22 & 2.42 & 0.027 & 0.12 & 1.07 & 0.011 & 0.093 & 0.023 & 5.71 & 20.7 \\
\hline Average $^{a}$ & nd & 8.47 & 0.33 & 5.98 & 4.85 & 0.015 & 0.22 & 1.23 & 0.16 & 0.19 & 0.092 & 1.42 & 18.1 \\
\hline
\end{tabular}

Rows with gray and blue shading are roof and floor strata samples and partings, respectively. bdl, below detection limit. nd, no data. ${ }^{\text {a }}$, averages for Chinese coals from Dai et al. (2012) [5]. 
As shown in Figure 17, the HTA (high temperature ash) and LTA yields of the Bole and Laibin coal samples are close to the diagonal equality line, but the LTA percentage is slightly higher than HTA, mainly due to the decomposition of clay and carbonate minerals during the high-temperature ashing process [1].

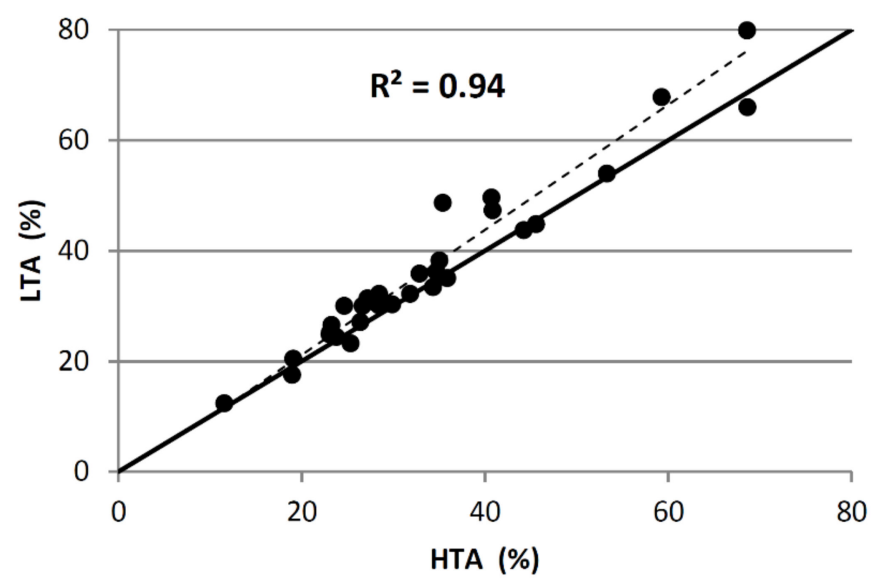

Figure 17. Comparison of HTA to LTA. LTA: low-temperature ash yields of coal samples. The diagonal line indicates equality and the dotted line is the trendline of LTA vs. HTA.

It is important to compare two data sets, i.e., the percentages of major element oxides (e.g., $\mathrm{Al}_{2} \mathrm{O}_{3}, \mathrm{SiO}_{2}, \mathrm{CaO}, \mathrm{MgO}, \mathrm{Fe}_{2} \mathrm{O}_{3}$, and $\mathrm{TiO}_{2}$, which are all on a $\mathrm{SO}_{3}$-free basis) inferred from the Siroquant analysis and the normalized values $\left(\mathrm{SO}_{3}\right.$-free and ash basis) of the same oxides obtained from the XRF analysis because such a comparison cannot only check the accuracy and reliability of the quantitative mineralogical data, but also can provide useful indications of the minerals chemistry, particularly where isomorphous substitution can occur, such as in illite and the carbonates [79,80]. Figure 18 shows the relationship between the proportion of major element oxides inferred from the XRD and Siroquant analysis and those obtained from the XRF data. The inferred percentages of $\mathrm{Al}_{2} \mathrm{O}_{3}$ and $\mathrm{SiO}_{2}$ from $\mathrm{XRD}$ are generally compatible with the normalized percentages determined by XRF (Figure 18A,B), while the inferred values of $\mathrm{CaO}$ are slightly lower than the observed values (Figure 18C), indicating that some Ca may also be present in clay minerals besides calcite. On the other hand, the inferred $\mathrm{MgO}$ are higher than the corresponding observed values (Figure 18D), and this may be explained by the low $\mathrm{Mg}$ contents in berthierine (B/C) determined by SEM-EDS (Figure 5F).

The majority of $\mathrm{Fe}_{2} \mathrm{O}_{3}$ and $\mathrm{TiO}_{2}$ plots fall close to the equality line, but underestimation of $\mathrm{Fe}_{2} \mathrm{O}_{3}$ and overestimation of $\mathrm{TiO}_{2}$ inferred from XRD are shown in some roof and floor samples (Figure 18E,F), which may be caused by Fe substitution for Ti in anatase. This is relatively abundant in the roof and floor samples.

\subsubsection{Trace Elements}

The trend of concentrations of trace elements in B1, B2, and B3 layers are similar to those in C1 Coal (Table 4, Figure 19). Compared with the averages for world hard coals [81] and based on the enrichment classification of trace elements in coal reported by Dai et al. [82], V, Co, Cu, Se, and $\mathrm{Y}$ in all the studied Bole and Laibin coals, as well as $\mathrm{Zn}, \mathrm{Zr}$, $\mathrm{Cd}$, La, and Hf in the B2 and C1 coals, are slightly enriched $(2<\mathrm{CC}<5, \mathrm{CC}$ is the ratio of the observed concentrations of elements vs. average value of the corresponding elements in hard coals worldwide), whereas other trace elements in the coals are either close to $(0.5<\mathrm{CC}<2)$ or depleted $(\mathrm{CC}<0.5)$ relative to the world averages. The concentrations of boron in the B1, B2, and B3 layers and C1 Coal are similar with averages of 2.13, 2.26, 1.86 , and $2.96 \mu \mathrm{g} / \mathrm{g}$, respectively, which is much lower than the average value for world hard coals $(47 \mu \mathrm{g} / \mathrm{g})$ [81]. Goodarzi and Swaine [83] suggested that such low $(<50 \mu \mathrm{g} / \mathrm{g})$ contents of $\mathrm{B}$ in coal are an indicator for a fresh water-influenced depositional environment. 

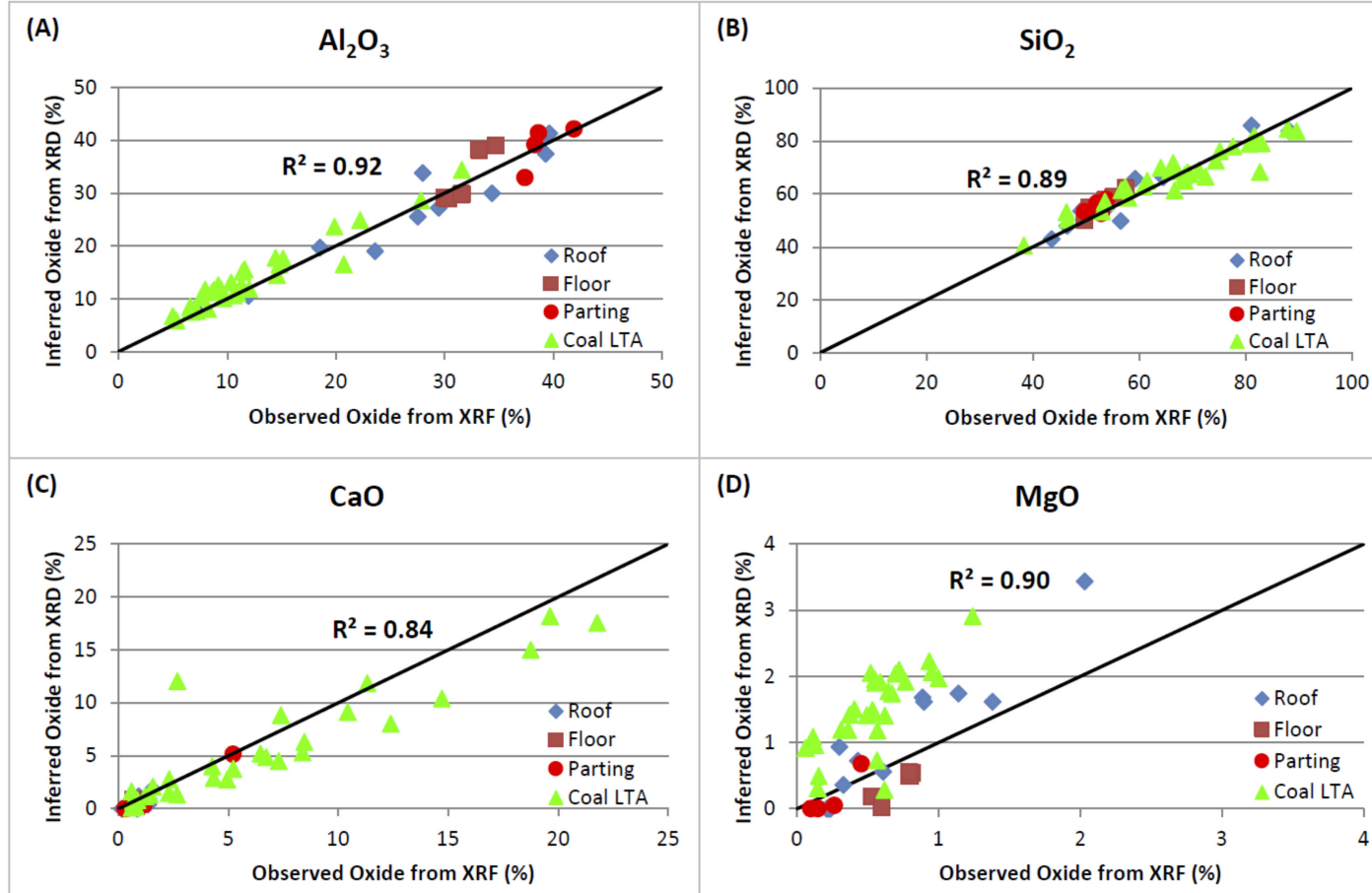

(D)
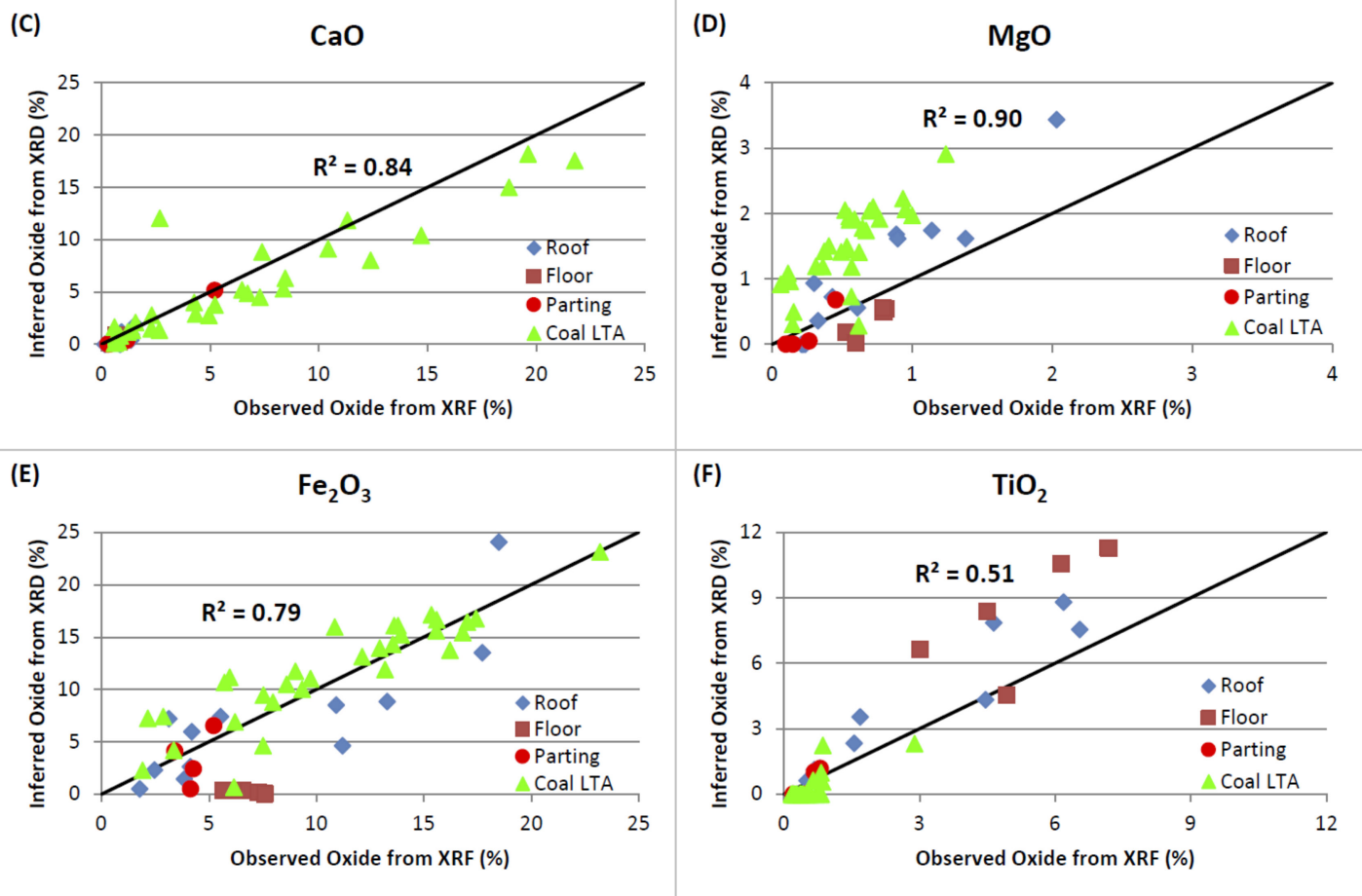

Figure 18. Comparison between the observed oxide percentages (normalized) from XRF and oxide percentages inferred from XRD analysis. The diagonal line in each plot indicates equality. (A), $\mathrm{Al}_{2} \mathrm{O}_{3} ;(\mathbf{B}), \mathrm{SiO}_{2} ;(\mathbf{C}), \mathrm{CaO}_{\mathbf{2}}(\mathbf{D}), \mathrm{MgO} ;(\mathbf{E}), \mathrm{Fe}_{2} \mathrm{O}_{3}$; (F), $\mathrm{TiO}_{2}$.

As with many Late Permian coals in Southwestern China, the Bole and Laibin coals are characterized by slight enrichment in $\mathrm{V}, \mathrm{Co}, \mathrm{Cu}$, and $\mathrm{Zn}$, which were likely derived from the sediment-source region, i.e., the Kangdian Upland, as reported by Dai et al. [84], Wang et al. [24], and Zhuang et al. [85].The concentrations of these elements are highly elevated in the roof and floor strata samples (except for samples B2-2r, C1-2r, C1-3r, C1-4r, and C1-5r), but are depleted in the four partings (B1-3p, B3-5p, C1-1t, and C1-8p) in comparison with the averages for world clays (Table 4) [86]. 
Table 4. Concentrations of trace elements ( $\mu \mathrm{g} / \mathrm{g}, \mathrm{Hg}$ in $\mathrm{ng} / \mathrm{g}$ ) in the Bole and Laibin coal benches, partings, and roof and floor strata samples.

\begin{tabular}{|c|c|c|c|c|c|c|c|c|c|c|c|c|c|c|c|c|c|c|c|c|c|c|c|c|c|}
\hline Sample & $\mathbf{L i}$ & $\mathrm{Be}$ & B & $F$ & Sc & $\mathrm{V}$ & $\mathrm{Cr}$ & Co & $\mathrm{Ni}$ & $\mathrm{Cu}$ & $\mathrm{Zn}$ & $\mathrm{Ga}$ & $\mathrm{Ge}$ & As & Se & $\mathbf{R b}$ & $\mathrm{Sr}$ & $Y$ & $\mathrm{Zr}$ & $\mathrm{Nb}$ & Mo & $\mathrm{Cd}$ & In & Sn & $\mathrm{Sb}$ \\
\hline B1-r & 45.3 & 3.38 & 13.5 & 277 & 36.3 & 359 & 123 & 86.1 & 125 & 275 & 131 & 39.7 & 1.43 & 52.0 & 3.00 & 53.8 & 305 & 57.2 & 570 & 62.8 & 17.1 & 1.06 & 0.17 & 4.73 & 0.87 \\
\hline B1-1 & 15.2 & 2.11 & 11.8 & 136 & 13.5 & 258 & 59.7 & 27.5 & 49.6 & 149 & 38.3 & 19.5 & 0.91 & 9.73 & 2.10 & 51.8 & 119 & 13.9 & 137 & 11.3 & 1.13 & 0.27 & 0.061 & 2.50 & 0.31 \\
\hline B1-2 & 8.98 & 0.88 & 0.08 & 41.3 & 5.01 & 28.5 & 7.87 & 16.1 & 22.5 & 16.9 & 62.9 & 7.92 & 1.45 & 3.55 & 2.90 & 9.34 & 59.9 & 56.8 & 75.9 & 6.21 & 5.50 & 0.74 & 0.042 & 1.35 & 0.32 \\
\hline B1-3p & 60.3 & 8.30 & 20.1 & 192 & 18.3 & 16.8 & 2.80 & 16.9 & 49.7 & 21.7 & 45.8 & 36.7 & 1.52 & 21.3 & 3.71 & 26.2 & 358 & 72.1 & 566 & 25.1 & 4.21 & 0.84 & 0.21 & 14.1 & 0.32 \\
\hline B1-4 & 6.32 & 1.40 & bdl & 29.1 & 3.73 & 25.6 & 7.17 & 25.5 & 27.7 & 21.9 & 43.4 & 5.71 & 1.26 & 1.88 & 3.95 & 3.66 & 31.5 & 28.7 & 31.7 & 3.78 & 1.69 & 0.19 & 0.032 & 0.73 & 0.65 \\
\hline B1-5 & 9.97 & 2.05 & 0.46 & 31.5 & 4.42 & 43.5 & 11.4 & 25.3 & 29.2 & 22.7 & 47.0 & 8.07 & 1.44 & 1.84 & 3.93 & 3.95 & 24.8 & 13.2 & 38.9 & 3.43 & 1.77 & 0.094 & 0.026 & 0.80 & 0.84 \\
\hline B1-6 & 8.33 & 1.65 & $\mathrm{bdl}$ & 35.0 & 3.21 & 40.0 & 7.81 & 21.4 & 24.0 & 22.9 & 42.6 & 6.45 & 1.47 & 1.08 & 4.70 & 2.39 & 67.1 & 16.7 & 45.0 & 4.36 & 3.86 & 0.14 & 0.030 & 1.31 & 0.88 \\
\hline B1-7 & 5.72 & 2.90 & $\mathrm{bdl}$ & 19.4 & 3.38 & 34.8 & 12.3 & 22.6 & 21.6 & 31.1 & 38.1 & 3.64 & 1.64 & 0.93 & 5.18 & 2.32 & 31.8 & 16.0 & 37.2 & 3.30 & 0.79 & 0.14 & 0.022 & 0.90 & 1.28 \\
\hline B1-8 & 7.52 & 2.04 & 0.37 & 37.3 & 4.54 & 30.9 & 21.0 & 10.8 & 10.6 & 18.4 & 15.2 & 3.15 & 1.54 & 0.44 & 4.79 & 3.10 & 28.8 & 11.6 & 51.0 & 5.24 & 2.08 & 0.095 & 0.013 & 0.86 & 1.08 \\
\hline B1-9 & 8.57 & 2.93 & bdl & 42.9 & 3.41 & 43.9 & 14.3 & 32.2 & 27.6 & 38.5 & 40.0 & 4.79 & 1.07 & 0.94 & 10.4 & 1.40 & 31.1 & 11.3 & 34.9 & 2.91 & 0.66 & 0.18 & 0.020 & 1.10 & 1.07 \\
\hline B1-f & 36.1 & 5.15 & 12.1 & 401 & 43.6 & 499 & 402 & 17.1 & 61.6 & 186 & 104 & 40.5 & 2.26 & 0.68 & 1.23 & 35.7 & 344 & 48.3 & 721 & 95.4 & 0.80 & 1.11 & 0.17 & 6.14 & 0.49 \\
\hline B2-1r & 14.9 & 4.04 & 13.1 & 529 & 21.0 & 130 & 68.2 & 16.2 & 39.1 & 70.8 & 96.1 & 32.3 & 1.78 & 2.98 & 0.63 & 78.4 & 327 & 42.8 & 286 & 38.8 & 2.31 & 1.00 & 0.15 & 8.65 & 0.58 \\
\hline B2-2r & 34.5 & 3.64 & 12.7 & 368 & 10.8 & 36.5 & 5.76 & 10.6 & 11.9 & 18.7 & 54.0 & 28.3 & 3.77 & 5.99 & 1.45 & 52.7 & 179 & 31.1 & 208 & 20.0 & 2.68 & 0.74 & 0.17 & 12.4 & 0.32 \\
\hline B2-3r & 21.9 & 3.55 & 9.36 & 628 & 20.8 & 241 & 108 & 56.0 & 123 & 136 & 163 & 32.4 & 2.02 & 7.62 & 1.58 & 42.7 & 220 & 61.6 & 385 & 43.7 & 0.72 & 0.96 & 0.10 & 4.40 & 0.72 \\
\hline B2-1 & 20.2 & 2.05 & 2.07 & 162 & 8.48 & 356 & 27.9 & 32.8 & 51.6 & 129 & 92.8 & 13.2 & 1.33 & 5.04 & 4.48 & 15.7 & 59.3 & 23.3 & 145 & 10.1 & 2.53 & 0.64 & 0.064 & 2.22 & 0.92 \\
\hline B2-2 & 65.1 & 4.02 & 6.93 & 191 & 12.1 & 39.6 & 19.0 & 16.6 & 28.7 & 12.8 & 42.6 & 28.0 & 1.41 & 1.63 & 4.79 & 15.2 & 108 & 55.4 & 466 & 28.9 & 1.63 & 0.70 & 0.13 & 9.25 & 0.30 \\
\hline B2-3 & 5.16 & 1.72 & bdl & 36.8 & 1.99 & 16.6 & 6.38 & 30.1 & 25.2 & 17.0 & 135 & 4.01 & 2.67 & 0.44 & 2.67 & 0.52 & 34.1 & 13.7 & 26.0 & 2.10 & 0.35 & 0.83 & 0.026 & 0.76 & 1.74 \\
\hline B2-4 & 8.04 & 2.53 & 0.73 & 36.0 & 2.89 & 46.3 & 13.6 & 31.2 & 27.0 & 33.8 & 31.7 & 3.79 & 3.16 & 0.44 & 5.31 & 2.76 & 31.0 & 8.04 & 30.6 & 2.69 & 0.53 & 0.13 & 0.018 & 1.00 & 2.10 \\
\hline B2-5 & 7.87 & 1.32 & 0.37 & 40.1 & 6.47 & 72.2 & 31.2 & 31.3 & 44.4 & 53.1 & 139 & 10.8 & 1.47 & 1.05 & 7.32 & 2.66 & 51.5 & 14.6 & 58.8 & 6.40 & 1.14 & 0.62 & 0.035 & 1.24 & 0.78 \\
\hline B2-f & 43.0 & 5.84 & 8.18 & 397 & 35.1 & 410 & 197 & 16.3 & 64.1 & 127 & 71.1 & 41.1 & 2.13 & 0.50 & 1.04 & 31.1 & 299 & 44.0 & 712 & 67.9 & 0.37 & 1.04 & 0.15 & 4.75 & 0.28 \\
\hline B3-r & 31.7 & 4.58 & 11.7 & 737 & 34.7 & 426 & 140 & 59.6 & 137 & 234 & 183 & 37.1 & 2.01 & 20.5 & 6.69 & 62.5 & 260 & 49.7 & 696 & 66.6 & 7.50 & 1.36 & 0.13 & 4.81 & 0.67 \\
\hline B3-3 & 5.41 & 1.96 & bdl & 27.4 & 2.77 & 42.3 & 9.63 & 20.8 & 21.6 & 19.7 & 24.0 & 3.94 & 2.99 & 0.45 & 5.73 & 1.17 & 31.3 & 13.5 & 28.9 & 2.79 & 0.18 & 0.062 & 0.020 & 0.90 & 0.94 \\
\hline B3-4 & 3.40 & 1.68 & $\mathrm{bdl}$ & 65.3 & 3.29 & 16.2 & 4.62 & 30.5 & 30.4 & 17.9 & 43.1 & 7.79 & 2.26 & 0.54 & 7.59 & 0.41 & 62.3 & 79.3 & 15.9 & 2.07 & 0.26 & 0.043 & 0.062 & 0.75 & 0.60 \\
\hline B3-5p & 79.5 & 6.25 & 1.77 & 87.1 & 10.1 & 5.58 & 2.75 & 14.0 & 30.7 & 9.85 & 27.3 & 41.7 & 2.78 & 0.65 & 4.66 & 1.43 & 63.9 & 45.3 & 319 & 29.9 & 3.07 & 0.46 & 0.24 & 17.9 & 0.59 \\
\hline B3-6 & 4.75 & 2.26 & bdl & 26.3 & 3.18 & 28.3 & 8.14 & 26.8 & 27.2 & 24.4 & 36.7 & 4.92 & 2.04 & 0.46 & 5.65 & 0.93 & 36.5 & 23.5 & 44.9 & 3.13 & 0.40 & 0.12 & 0.034 & 0.86 & 0.78 \\
\hline B3-7 & 3.27 & 1.57 & 0.86 & 30.5 & 3.24 & 75.5 & 12.8 & 23.1 & 27.1 & 40.2 & 93.6 & 4.77 & 1.70 & 0.65 & 8.07 & 1.50 & 50.5 & 18.3 & 28.2 & 2.68 & 0.64 & 0.35 & 0.024 & 0.46 & 0.52 \\
\hline B3-f & 27.8 & 4.16 & 9.93 & 324 & 34.6 & 353 & 280 & 18.4 & 77.6 & 162 & 76.7 & 39.9 & 2.84 & 0.73 & 2.73 & 23.5 & 277 & 53.3 & 653 & 74.6 & 1.26 & 0.91 & 0.17 & 6.48 & 0.26 \\
\hline $\mathrm{C} 1-1 \mathrm{r}$ & 49.8 & 3.83 & 9.84 & 321 & 43.3 & 423 & 114 & 22.9 & 61.8 & 381 & 233 & 39.5 & 1.44 & 3.92 & 1.80 & 15.9 & 188 & 70.4 & 680 & 75.5 & 3.47 & 5.76 & 0.20 & 5.54 & 0.31 \\
\hline $\mathrm{C} 1-2 \mathrm{r}$ & 7.40 & 1.82 & 11.4 & 52.5 & 5.47 & 144 & 20.9 & 23.5 & 29.9 & 24.7 & 249 & 5.92 & 11.9 & 2.96 & 1.93 & 17.2 & 18.3 & 6.19 & 48.2 & 5.63 & 2.43 & 4.81 & 0.030 & 1.14 & 1.87 \\
\hline C1-3r & 13.5 & 3.31 & 18.8 & 148 & 3.45 & 13.6 & 2.68 & 9.84 & 27.1 & 35.0 & 28.1 & 37.1 & 2.22 & 4.60 & 3.46 & 2.15 & 100 & 31.9 & 470 & 28.8 & 4.35 & 0.94 & 0.21 & 13.0 & 0.47 \\
\hline C1-4r & 22.5 & 2.91 & 9.56 & 132 & 4.05 & 16.2 & 4.78 & 11.4 & 25.5 & 17.6 & 33.1 & 36.7 & 3.19 & 4.76 & 4.07 & 3.30 & 60.7 & 53.2 & 614 & 25.7 & 5.13 & 0.88 & 0.20 & 12.6 & 0.58 \\
\hline C1-5r & 19.1 & 2.92 & 9.99 & 166 & 2.86 & 14.2 & 3.36 & 11.2 & 27.3 & 18.2 & 37.5 & 39.5 & 2.34 & 4.11 & 3.41 & 1.71 & 52.3 & 29.3 & 531 & 22.1 & 8.52 & 0.88 & 0.21 & 13.3 & 0.46 \\
\hline C1-6r & 28.8 & 3.12 & 7.80 & 479 & 49.2 & 584 & 198 & 48.0 & 89.4 & 351 & 212 & 36.1 & 1.31 & 2.21 & 1.65 & 20.7 & 122 & 63.3 & 586 & 69.7 & 2.25 & 1.12 & 0.17 & 4.96 & 0.28 \\
\hline $\mathrm{C} 1-7 \mathrm{r}$ & 18.8 & 1.85 & 13.9 & 113 & 7.46 & 103 & 38.1 & 10.7 & 17.5 & 12.2 & 40.2 & 14.6 & 5.57 & 3.10 & 3.09 & 34.8 & 40.0 & 14.5 & 83.5 & 9.90 & 1.08 & 0.24 & 0.058 & 2.22 & 0.84 \\
\hline C1-1t & 46.7 & 2.88 & 5.84 & 96.3 & 4.96 & 14.8 & 2.65 & 9.64 & 19.7 & 25.9 & 34.2 & 35.1 & 1.75 & 1.83 & 2.94 & 2.23 & 24.1 & 48.6 & 669 & 33.2 & 2.09 & 0.93 & 0.24 & 15.5 & 0.23 \\
\hline C1-2 & 6.31 & 2.70 & 5.33 & 17.6 & 3.70 & 15.7 & 9.98 & 18.7 & 11.7 & 8.58 & 41.9 & 5.98 & 8.25 & 1.78 & 3.48 & 1.65 & 11.0 & 18.5 & 56.1 & 5.20 & 1.25 & 0.17 & 0.030 & 1.40 & 1.38 \\
\hline C1-3 & 5.29 & 2.95 & 5.82 & 16.8 & 2.18 & 13.7 & 7.46 & 26.8 & 13.1 & 12.1 & 16.5 & 4.23 & 16.9 & 0.98 & 2.24 & 1.15 & 9.26 & 14.5 & 17.2 & 1.56 & 2.73 & 0.098 & 0.016 & 0.44 & 2.27 \\
\hline C1-4 & 9.24 & 2.43 & 5.91 & 28.4 & 2.95 & 14.2 & 7.29 & 17.2 & 9.70 & 15.8 & 118 & 4.34 & 12.2 & 1.25 & 3.96 & 1.24 & 13.9 & 15.7 & 38.8 & 3.06 & 6.65 & 3.05 & 0.026 & 1.57 & 1.54 \\
\hline C1-5 & 6.51 & 2.86 & 10.2 & 18.0 & 1.86 & 16.2 & 6.98 & 34.2 & 23.5 & 18.1 & 191 & 5.64 & 20.6 & 0.69 & 3.71 & 0.163 & 12.9 & 6.30 & 21.8 & 1.71 & 3.72 & 3.15 & 0.018 & 0.70 & 2.17 \\
\hline C1-6 & 7.67 & 2.32 & 3.61 & 22.2 & 4.56 & 96.4 & 12.5 & 16.6 & 13.9 & 53.7 & 24.1 & 3.98 & 3.67 & 1.03 & 7.33 & 3.42 & 12.9 & 12.5 & 48.8 & 3.75 & 1.47 & 0.19 & 0.026 & 1.15 & 0.90 \\
\hline C1-7 & 7.31 & 3.09 & 9.76 & 16.5 & 2.14 & 32.2 & 5.72 & 25.8 & 16.2 & 17.7 & 26.7 & 4.55 & 8.87 & 0.64 & 3.85 & 0.35 & 9.93 & 9.42 & 31.1 & 2.26 & 1.75 & 0.12 & 0.014 & 0.80 & 2.01 \\
\hline
\end{tabular}


Table 4. Cont.

\begin{tabular}{|c|c|c|c|c|c|c|c|c|c|c|c|c|c|c|c|c|c|c|c|c|c|c|c|c|c|}
\hline Sample & $\mathrm{Li}$ & Be & B & $F$ & Sc & $\mathrm{V}$ & $\mathrm{Cr}$ & Co & $\mathrm{Ni}$ & $\mathrm{Cu}$ & $\mathrm{Zn}$ & $\mathrm{Ga}$ & $\mathrm{Ge}$ & As & $\mathrm{Se}$ & $\mathbf{R b}$ & $\mathrm{Sr}$ & $\mathrm{Y}$ & $\mathrm{Zr}$ & $\mathrm{Nb}$ & Mo & $\mathrm{Cd}$ & In & Sn & $\mathrm{Sb}$ \\
\hline C1-8p & 89.8 & 3.09 & 11.1 & 163 & 2.34 & 12.4 & 3.30 & 10.2 & 25.1 & 21.9 & 41.2 & 28.8 & 2.18 & 0.91 & 1.99 & 4.04 & 38.0 & 6.03 & 182 & 22.9 & 0.50 & 0.28 & 0.18 & 14.0 & 0.39 \\
\hline C1-9 & 33.7 & 3.13 & 13.6 & 62.8 & 7.22 & 30.0 & 12.9 & 18.7 & 19.1 & 15.6 & 47.5 & 13.8 & 5.36 & 0.45 & 3.93 & 7.78 & 19.3 & 47.2 & 174 & 11.9 & 1.10 & 0.35 & 0.068 & 4.13 & 1.25 \\
\hline C1-10 & 27.4 & 3.12 & 8.49 & 51.9 & 2.25 & 40.5 & 24.1 & 10.5 & 12.8 & 18.6 & 21.9 & 9.15 & 2.93 & 0.53 & 4.05 & 3.52 & 22.4 & 12.4 & 176 & 12.8 & 0.79 & 0.34 & 0.045 & 3.33 & 0.76 \\
\hline C1-11 & 6.40 & 2.76 & 6.58 & 19.4 & 3.39 & 32.6 & 8.08 & 28.7 & 24.6 & 46.4 & 204 & 7.76 & 15.0 & 1.69 & 6.57 & 0.60 & 12.7 & 34.7 & 40.8 & 2.59 & 1.07 & 2.62 & 0.032 & 0.72 & 2.53 \\
\hline C1-12 & 6.83 & 3.14 & 3.87 & 16.7 & 3.41 & 34.7 & 11.8 & 21.9 & 17.9 & 24.7 & 31.2 & 5.29 & 5.82 & 1.45 & 5.26 & 1.16 & 10.2 & 22.7 & 42.5 & 3.28 & 0.42 & 0.12 & 0.016 & 1.07 & 1.46 \\
\hline C1-13 & 33.6 & 3.02 & 9.90 & 62.4 & 9.66 & 168 & 36.8 & 27.9 & 43.2 & 178 & 71.6 & 13.7 & 5.16 & 3.15 & 9.13 & 13.8 & 23.9 & 20.8 & 71.3 & 6.25 & 0.74 & 0.31 & 0.040 & 1.10 & 1.29 \\
\hline C1-14 & 99.2 & 4.88 & 11.1 & 145 & 30.1 & 373 & 112 & 27.2 & 88.4 & 275 & 68.5 & 33.4 & 2.40 & 4.53 & 4.90 & 16.6 & 80.0 & 55.5 & 420 & 36.1 & 1.39 & 0.64 & 0.11 & 4.10 & 0.37 \\
\hline C1-1f & 65.2 & 4.44 & 8.40 & 139 & 32.5 & 569 & 159 & 30.8 & 90.1 & 914 & 96.6 & 45.1 & 2.03 & 2.83 & 4.83 & 7.05 & 121 & 51.7 & 766 & 69.8 & 1.89 & 1.13 & 0.18 & 5.77 & 0.35 \\
\hline C1-2f & 41.2 & 3.98 & 8.65 & 194 & 38.8 & 544 & 277 & 18.3 & 68.4 & 152 & 111 & 47.5 & 1.50 & 1.36 & 0.73 & 11.3 & 140 & 41.1 & 918 & 98.0 & 2.04 & 1.28 & 0.21 & 6.37 & 0.24 \\
\hline WA-B1 & 8.68 & 2.13 & 1.51 & 46.3 & 5.01 & 63.0 & 17.7 & 23.6 & 26.7 & 41.6 & 41.0 & 7.11 & 1.33 & 2.44 & 5.28 & 9.33 & 49.2 & 20.5 & 55.5 & 4.92 & 2.02 & 0.23 & 0.030 & 1.21 & 0.85 \\
\hline WA-B3 & 4.89 & 1.86 & 0.10 & 40.5 & 3.45 & 72.7 & 11.7 & 27.5 & 29.3 & 45.5 & 46.7 & 5.23 & 2.10 & 1.08 & 5.72 & 2.20 & 39.5 & 20.0 & 38.1 & 3.11 & 0.71 & 0.16 & 0.028 & 0.80 & 0.81 \\
\hline WA-C1 & 17.6 & 2.96 & 8.56 & 35.4 & 5.18 & 62.3 & 16.4 & 23.7 & 22.5 & 49.9 & 69.8 & 8.37 & 8.96 & 1.30 & 5.03 & 4.13 & 16.7 & 20.8 & 77.0 & 5.93 & 1.83 & 0.84 & 0.03 & 1.58 & 1.57 \\
\hline World $^{\mathrm{a}}$ & 14 & 2 & 47 & 82 & 3.7 & 28 & 17 & 6 & 17 & 16 & 28 & 6 & 2.4 & 8.3 & 1.3 & 18 & 100 & 8.4 & 36 & 4 & 2.1 & 0.2 & 0.04 & 1.4 & 1 \\
\hline Sample & Cs & Ba & La & $\mathrm{Ce}$ & $\operatorname{Pr}$ & Nd & $\mathrm{Sm}$ & Eu & Gd & $\mathrm{Tb}$ & Dy & Ho & $\mathrm{Er}$ & $\operatorname{Tm}$ & $\mathrm{Yb}$ & Lu & $\mathrm{Hf}$ & Ta & Hg ng/g & $\mathrm{Tl}$ & $\mathrm{Pb}$ & $\mathbf{B i}$ & Th & $\mathrm{U}$ & REY \\
\hline B1-r & 3.11 & 614 & 87.5 & 172 & 19.2 & 74.4 & 11.7 & 2.77 & 13.2 & 1.88 & 12.1 & 2.41 & 7.34 & 0.99 & 6.62 & 0.92 & 13.6 & 3.80 & 94.3 & 0.17 & 17.0 & 0.34 & 16.5 & 4.12 & 471 \\
\hline B1-1 & 4.58 & 315 & 28.2 & 61.6 & 6.72 & 25.4 & 3.86 & 0.71 & 3.74 & 0.45 & 2.84 & 0.59 & 1.88 & 0.27 & 1.85 & 0.27 & 4.32 & 0.86 & 138 & 0.22 & 6.91 & 0.14 & 8.96 & 2.20 & 152 \\
\hline B1-2 & 2.30 & 52.0 & 64.8 & 155 & 16.7 & 64.0 & 13.0 & 2.26 & 13.6 & 2.19 & 10.1 & 2.04 & 5.08 & 0.67 & 4.02 & 0.62 & 1.42 & 0.28 & 331 & 0.055 & 8.08 & 0.12 & 4.04 & 4.10 & 411 \\
\hline B1-3p & 1.46 & 1141 & 73.8 & 172 & 18.9 & 77.9 & 16.0 & 2.47 & 16.0 & 2.35 & 13.6 & 3.12 & 8.56 & 1.51 & 8.89 & 1.48 & 17.7 & 3.05 & 383 & 0.079 & 11.7 & 1.80 & 72.0 & 11.3 & 489 \\
\hline B1-4 & 0.98 & 24.0 & 13.0 & 28.9 & 3.28 & 12.8 & 2.98 & 0.61 & 3.62 & 0.77 & 4.40 & 0.99 & 2.67 & 0.38 & 2.32 & 0.37 & 0.774 & 0.17 & 80.7 & 0.015 & 13.2 & 0.13 & 1.73 & 1.47 & 106 \\
\hline B1-7 & 0.29 & 22.6 & 13.0 & 31.2 & 3.69 & 14.6 & 3.01 & 0.67 & 3.29 & 0.54 & 2.69 & 0.58 & 1.60 & 0.23 & 1.48 & 0.23 & 1.32 & 0.23 & 20.2 & 0.011 & 13.1 & 0.19 & 2.86 & 0.81 & 92.8 \\
\hline B1-8 & 0.36 & 47.9 & 13.6 & 29.5 & 3.46 & 14.1 & 2.76 & 0.58 & 2.95 & 0.39 & 2.30 & 0.44 & 1.37 & 0.19 & 1.37 & 0.20 & 1.42 & 0.40 & 19.1 & 0.002 & 12.7 & 0.19 & 5.23 & 0.99 & 84.7 \\
\hline B1-9 & 0.17 & 14.8 & 11.7 & 27.1 & 3.17 & 12.7 & 2.68 & 0.62 & 2.81 & 0.45 & 2.12 & 0.44 & 1.19 & 0.17 & 1.17 & 0.19 & 1.37 & 0.33 & 26.7 & 0.003 & 19.2 & 0.26 & 3.01 & 0.82 & 77.8 \\
\hline B1-f & 2.71 & 244 & 73.9 & 154 & 16.4 & 62.8 & 11.5 & 2.90 & 12.3 & 1.80 & 10.9 & 2.00 & 5.61 & 0.71 & 4.49 & 0.63 & 17.1 & 5.94 & 10.7 & 0.12 & 14.6 & 0.16 & 22.3 & 5.91 & 408 \\
\hline B2-1r & 3.85 & 244 & 52.3 & 108 & 11.5 & 43.6 & 8.28 & 1.47 & 8.84 & 1.32 & 8.89 & 1.80 & 5.81 & 0.86 & 6.39 & 0.93 & 8.67 & 2.92 & 48.5 & 0.25 & 9.25 & 0.76 & 35.0 & 10.4 & 303 \\
\hline B2-2r & 4.28 & 140 & 32.2 & 90.6 & 10.3 & 45.1 & 10.6 & 1.59 & 9.44 & 1.23 & 6.73 & 1.22 & 3.71 & 0.55 & 4.22 & 0.62 & 8.57 & 3.04 & 55.0 & 0.17 & 17.3 & 1.17 & 48.2 & 14.7 & 249 \\
\hline B2-3r & 3.43 & 157 & 78.7 & 182 & 20.2 & 82.6 & 16.9 & 2.72 & 15.6 & 2.06 & 12.3 & 2.40 & 7.62 & 1.09 & 7.64 & 1.09 & 9.50 & 2.63 & 20.9 & 0.13 & 9.72 & 0.14 & 16.1 & 6.50 & 495 \\
\hline B2-1 & 2.38 & 70.6 & 55.9 & 125 & 13.6 & 54.3 & 11.0 & 1.76 & 10.4 & 1.15 & 5.47 & 0.95 & 2.72 & 0.36 & 2.53 & 0.35 & 3.69 & 0.66 & 19.3 & 0.077 & 21.8 & 0.24 & 10.5 & 4.31 & 309 \\
\hline B2-2 & 1.71 & 101 & 58.5 & 130 & 13.8 & 54.5 & 11.3 & 1.98 & 12.3 & 1.79 & 11.1 & 2.15 & 6.56 & 0.92 & 6.28 & 0.87 & 12.4 & 2.43 & 33.7 & 0.046 & 32.2 & 0.87 & 40.7 & 8.77 & 367 \\
\hline B2-3 & 0.051 & 14.5 & 6.53 & 13.8 & 1.60 & 6.48 & 1.60 & 0.37 & 1.94 & 0.41 & 2.24 & 0.47 & 1.23 & 0.17 & 1.09 & 0.17 & 1.05 & 0.25 & 68.1 & 0.001 & 10.2 & 0.13 & 2.19 & 0.87 & 51.8 \\
\hline B2-4 & 0.27 & 20.6 & 5.86 & 11.6 & 1.34 & 5.39 & 1.14 & 0.29 & 1.36 & 0.25 & 1.37 & 0.29 & 0.76 & 0.11 & 0.72 & 0.12 & 1.15 & 0.18 & 15.4 & 0.009 & 13.7 & 0.19 & 2.16 & 0.67 & 38.6 \\
\hline B2-5 & 0.31 & 26.8 & 60.7 & 143 & 16.1 & 64.0 & 11.6 & 2.73 & 11.7 & 1.35 & 3.89 & 0.62 & 1.39 & 0.17 & 1.24 & 0.18 & 2.28 & 0.66 & 36.5 & 0.017 & 28.9 & 0.21 & 3.98 & 1.26 & 333 \\
\hline B2-f & 1.86 & 191 & 59.4 & 104 & 9.06 & 29.9 & 5.06 & 1.62 & 7.51 & 1.32 & 8.45 & 1.89 & 4.78 & 0.75 & 4.12 & 0.67 & 17.2 & 4.66 & 9.19 & 0.084 & 7.09 & 0.23 & 23.4 & 4.24 & 283 \\
\hline B3-r & 3.45 & 170 & 99.2 & 198 & 20.4 & 70.9 & 10.7 & 2.64 & 12.6 & 1.68 & 10.2 & 1.97 & 5.78 & 0.78 & 5.12 & 0.72 & 16.9 & 4.32 & 28.2 & 0.20 & 35.0 & 0.12 & 18.2 & 3.96 & 490 \\
\hline B3-1 & 1.12 & 35.3 & 14.7 & 31.9 & 3.57 & 13.2 & 2.20 & 0.50 & 2.52 & 0.34 & 1.54 & 0.33 & 0.91 & 0.13 & 0.90 & 0.14 & 2.43 & 0.53 & 24.7 & 0.051 & 21.2 & 0.14 & 3.15 & 0.79 & 81.2 \\
\hline B3-2 & 0.14 & 17.0 & 9.14 & 21.8 & 2.73 & 10.9 & 2.39 & 0.43 & 2.38 & 0.37 & 1.71 & 0.36 & 0.99 & 0.14 & 0.92 & 0.14 & 0.941 & 0.22 & 25.5 & 0.001 & 14.7 & 0.12 & 1.65 & 0.67 & 64.3 \\
\hline B3-3 & 0.099 & 18.6 & 8.63 & 18.9 & 2.31 & 9.14 & 2.04 & 0.37 & 2.30 & 0.4 & 2.16 & 0.47 & 1.3 & 0.19 & 1.22 & 0.19 & 1.18 & 0.32 & 47.0 & bdl & 14.0 & 0.13 & 3.38 & 0.89 & 63.1 \\
\hline B3-4 & 0.058 & 10.4 & 22.9 & 55.3 & 6.75 & 27.7 & 7.85 & 1.26 & 9.33 & 2.26 & 13.2 & 2.86 & 7.55 & 1.05 & 6.35 & 0.97 & 0.882 & 0.15 & 27.9 & bdl & 20.3 & 0.11 & 1.34 & 3.25 & 245 \\
\hline B3-5p & 0.20 & 34.9 & 31.5 & 69.7 & 7.05 & 27.8 & 6.11 & 0.45 & 6.76 & 1.20 & 7.91 & 1.83 & 5.19 & 0.96 & 5.87 & 0.93 & 10.3 & 4.11 & 22.1 & 0.008 & 18.7 & 1.84 & 66.9 & 9.90 & 219 \\
\hline
\end{tabular}


Table 4. Cont.

\begin{tabular}{|c|c|c|c|c|c|c|c|c|c|c|c|c|c|c|c|c|c|c|c|c|c|c|c|c|c|}
\hline Sample & $\mathbf{L i}$ & $\mathrm{Be}$ & B & F & Sc & $\mathrm{V}$ & $\mathrm{Cr}$ & Co & $\mathrm{Ni}$ & $\mathrm{Cu}$ & $\mathrm{Zn}$ & $\mathrm{Ga}$ & $\mathrm{Ge}$ & As & Se & $\mathbf{R b}$ & $\mathrm{Sr}$ & $Y$ & $\mathrm{Zr}$ & $\mathrm{Nb}$ & Mo & $\mathrm{Cd}$ & In & Sn & $\mathrm{Sb}$ \\
\hline B3-6 & 0.11 & 13.6 & 22.1 & 46.9 & 5.29 & 20.4 & 4.26 & 0.64 & 4.71 & 0.79 & 4.00 & 0.88 & 2.51 & 0.37 & 2.49 & 0.40 & 1.57 & 0.25 & 14.4 & $\mathrm{bdl}$ & 14.4 & 0.22 & 3.73 & 1.42 & 139 \\
\hline B3-7 & 0.15 & 21.3 & 27.2 & 56.0 & 6.49 & 26.1 & 5.11 & 1.18 & 5.71 & 0.81 & 3.32 & 0.65 & 1.70 & 0.23 & 1.53 & 0.24 & 0.940 & 0.21 & 22.4 & 0.007 & 17.7 & 0.11 & 1.98 & 0.68 & 155 \\
\hline B3-f & 1.93 & 175 & 97.4 & 231 & 25.3 & 102 & 19.8 & 4.71 & 19.1 & 2.40 & 12.9 & 2.25 & 6.26 & 0.81 & 5.46 & 0.75 & 16.1 & 5.00 & 5.87 & 0.061 & 16.8 & 0.44 & 25.8 & 5.82 & 584 \\
\hline C1-1r & 0.93 & 217 & 107 & 181 & 22.1 & 86.8 & 15.8 & 3.76 & 15.7 & 2.24 & 13.1 & 2.98 & 7.84 & 1.29 & 7.24 & 1.21 & 16.3 & 5.00 & 37.6 & 0.23 & 20.2 & 0.17 & 14.1 & 3.75 & 538 \\
\hline $\mathrm{C} 1-3 \mathrm{r}$ & 0.19 & 54.8 & 30.3 & 133 & 7.98 & 32.4 & 6.71 & 1.00 & 7.14 & 0.95 & 5.65 & 1.12 & 3.57 & 0.52 & 3.78 & 0.54 & 17.5 & 3.16 & 44.2 & 0.010 & 19.8 & 1.52 & 51.3 & 9.29 & 266 \\
\hline C1-4r & 0.44 & 37.8 & 158 & 406 & 39.8 & 154 & 29.1 & 3.93 & 26.3 & 2.83 & 13.2 & 2.24 & 6.47 & 0.86 & 5.99 & 0.84 & 17.3 & 2.87 & 47.6 & 0.034 & 19.4 & 1.41 & 70.2 & 14.9 & 903 \\
\hline C1-5r & 0.18 & 29.4 & 77.5 & 231 & 19.4 & 75.9 & 14.1 & 1.93 & 13.2 & 1.44 & 6.97 & 1.21 & 3.55 & 0.49 & 3.41 & 0.48 & 18.3 & 3.12 & 44.4 & 0.002 & 16.7 & 1.58 & 64.3 & 10.4 & 480 \\
\hline C1-6r & 0.70 & 156 & 67.7 & 148 & 16.7 & 70.3 & 14.5 & 3.91 & 15.2 & 2.04 & 12.2 & 2.34 & 7.07 & 0.96 & 6.41 & 0.91 & 13.8 & 4.23 & 10.1 & 0.093 & 18.4 & 0.092 & 12.1 & 3.12 & 432 \\
\hline $\mathrm{C} 1-7 \mathrm{r}$ & 6.32 & 116 & 38.0 & 91.7 & 9.10 & 37.9 & 7.24 & 1.28 & 7.03 & 0.76 & 3.60 & 0.62 & 1.71 & 0.23 & 1.63 & 0.22 & 2.46 & 0.69 & 7.86 & 0.225 & 9.10 & 0.50 & 8.33 & 2.05 & 215 \\
\hline C1-2 & 0.29 & 24.1 & 37.1 & 82.5 & 8.74 & 32.4 & 6.57 & 0.90 & 7.10 & 0.99 & 3.89 & 0.73 & 1.90 & 0.27 & 1.82 & 0.28 & 1.66 & 0.33 & 8.30 & 0.025 & 11.7 & 0.24 & 4.33 & 2.42 & 204 \\
\hline C1-3 & 0.17 & 13.4 & 9.82 & 25.9 & 3.11 & 11.8 & 2.48 & 0.37 & 2.73 & 0.45 & 2.27 & 0.50 & 1.31 & 0.18 & 1.18 & 0.19 & 0.68 & 0.14 & 5.28 & 0.025 & 4.87 & 0.084 & 1.14 & 0.70 & 76.8 \\
\hline C1-4 & 0.15 & 18.5 & 8.25 & 20.9 & 2.50 & 9.58 & 2.14 & 0.33 & 2.41 & 0.44 & 2.36 & 0.51 & 1.38 & 0.19 & 1.25 & 0.20 & 1.56 & 0.41 & 23.1 & 0.033 & 10.3 & 0.21 & 5.97 & 1.24 & 68.1 \\
\hline C1-5 & 0.01 & 5.55 & 2.07 & 5.01 & 0.63 & 2.60 & 0.73 & 0.11 & 0.81 & 0.16 & 0.92 & 0.19 & 0.53 & 0.073 & 0.49 & 0.075 & 0.93 & 0.14 & 27.8 & 0.011 & 9.16 & 0.15 & 1.28 & 0.66 & 20.7 \\
\hline C1-6 & 0.43 & 23.7 & 17.1 & 38.5 & 4.35 & 16.0 & 3.16 & 0.41 & 3.38 & 0.47 & 1.99 & 0.43 & 1.20 & 0.18 & 1.21 & 0.19 & 1.94 & 0.23 & 11.1 & 0.047 & 17.0 & 0.22 & 4.51 & 1.27 & 101 \\
\hline C1-7 & 0.043 & 4.79 & 2.33 & 5.70 & 0.76 & 3.39 & 1.10 & 0.13 & 1.15 & 0.25 & 1.46 & 0.32 & 0.89 & 0.13 & 0.91 & 0.14 & 1.25 & 0.23 & 11.5 & 0.005 & 12.0 & 0.15 & 2.37 & 0.64 & 28.1 \\
\hline $\mathrm{C} 1-8 \mathrm{p}$ & 0.51 & 38.3 & 12.7 & 51.6 & 2.89 & 11.2 & 2.25 & 0.10 & 2.40 & 0.27 & 1.49 & 0.27 & 0.81 & 0.12 & 0.92 & 0.13 & 7.59 & 3.22 & 10.7 & 0.010 & 10.5 & 1.09 & 29.6 & 8.80 & 93.1 \\
\hline C1-9 & 1.28 & 36.7 & 54.0 & 118 & 12.4 & 45.6 & 10.1 & 0.93 & 11.0 & 1.79 & 8.78 & 1.83 & 4.96 & 0.74 & 4.80 & 0.74 & 6.62 & 1.50 & 6.51 & 0.045 & 17.1 & 0.48 & 17.0 & 6.41 & 323 \\
\hline C1-10 & 0.43 & 38.1 & 36.4 & 63.4 & 8.84 & 32.5 & 6.06 & 1.07 & 6.53 & 0.80 & 2.86 & 0.53 & 1.36 & 0.19 & 1.27 & 0.18 & 6.41 & 1.38 & 4.84 & 0.025 & 11.9 & 0.37 & 9.38 & 2.56 & 174 \\
\hline C1-11 & 0.052 & 7.74 & 27.8 & 58.5 & 6.55 & 25.1 & 5.18 & 1.08 & 6.08 & 1.04 & 5.26 & 1.16 & 3.11 & 0.45 & 2.84 & 0.45 & 1.56 & 0.23 & 23.3 & 0.049 & 16.1 & 0.23 & 2.59 & 1.32 & 179 \\
\hline C1-14 & 1.24 & 130 & 174 & 405 & 44.2 & 179 & 33.4 & 8.52 & 31.2 & 3.41 & 15.4 & 2.37 & 6.13 & 0.77 & 5.25 & 0.70 & 10.5 & 2.55 & 17.8 & 0.24 & 11.3 & 0.40 & 16.7 & 4.85 & 965 \\
\hline C1-1f & 0.44 & 159 & 75.8 & 165 & 17.6 & 72.7 & 14.1 & 3.73 & 14.2 & 2.04 & 11.3 & 2.41 & 5.97 & 0.94 & 5.05 & 0.80 & 18.2 & 4.50 & 67.2 & 0.14 & 17.4 & 0.26 & 19.4 & 5.83 & 443 \\
\hline C1-2f & 0.47 & 179 & 43.1 & 77.5 & 7.82 & 30.0 & 6.05 & 1.74 & 7.27 & 1.33 & 8.37 & 1.78 & 4.20 & 0.62 & 3.37 & 0.54 & 21.5 & 5.82 & 12.4 & 0.071 & 24.0 & 0.26 & 19.9 & 4.48 & 235 \\
\hline WA-B1 & 1.17 & 63.6 & 20.5 & 47.4 & 5.32 & 20.7 & 4.14 & 0.82 & 4.41 & 0.71 & 3.60 & 0.75 & 2.03 & 0.28 & 1.81 & 0.28 & 1.69 & 0.36 & 91.8 & 0.040 & 13.0 & 0.18 & 4.09 & 1.54 & 133 \\
\hline WA-B2 & 0.62 & 37.1 & 29.0 & 65.5 & 7.22 & 28.7 & 5.71 & 1.17 & 6.00 & 0.83 & 4.01 & 0.76 & 2.12 & 0.29 & 1.98 & 0.29 & 3.36 & 0.70 & 38.4 & 0.020 & 19.2 & 0.29 & 9.44 & 2.45 & 173 \\
\hline WA-B3 & 0.26 & 19.0 & 17.2 & 37.3 & 4.32 & 16.9 & 3.57 & 0.64 & 3.97 & 0.68 & 3.40 & 0.73 & 2.02 & 0.29 & 1.90 & 0.30 & 1.42 & 0.29 & 25.3 & 0.009 & 16.1 & 0.16 & 2.93 & 1.14 & 113 \\
\hline WA-C1 & 0.53 & 25.9 & 30.7 & 67.9 & 7.54 & 29.0 & 5.85 & 1.08 & 6.18 & 0.88 & 3.93 & 0.77 & 2.05 & 0.29 & 1.94 & 0.30 & 2.67 & 0.56 & 14.9 & 0.05 & 13.6 & 0.23 & 5.76 & 2.03 & 179 \\
\hline World a & 1.1 & 150 & 11 & 23 & 3.4 & 12 & 2.2 & 0.43 & 2.7 & 0.31 & 2.1 & 0.57 & 1 & 0.3 & 1 & 0.2 & 1.2 & 0.3 & 100 & 0.58 & 9 & 1.1 & 3.2 & 1.9 & 68.6 \\
\hline
\end{tabular}

Rows with gray and blue shading are roof and floor strata samples and partings, respectively. bdl, below detection limit. nd, no data. ${ }^{\text {a }}$, averages for world hard coals from Ketris and Yudovich [81]. 

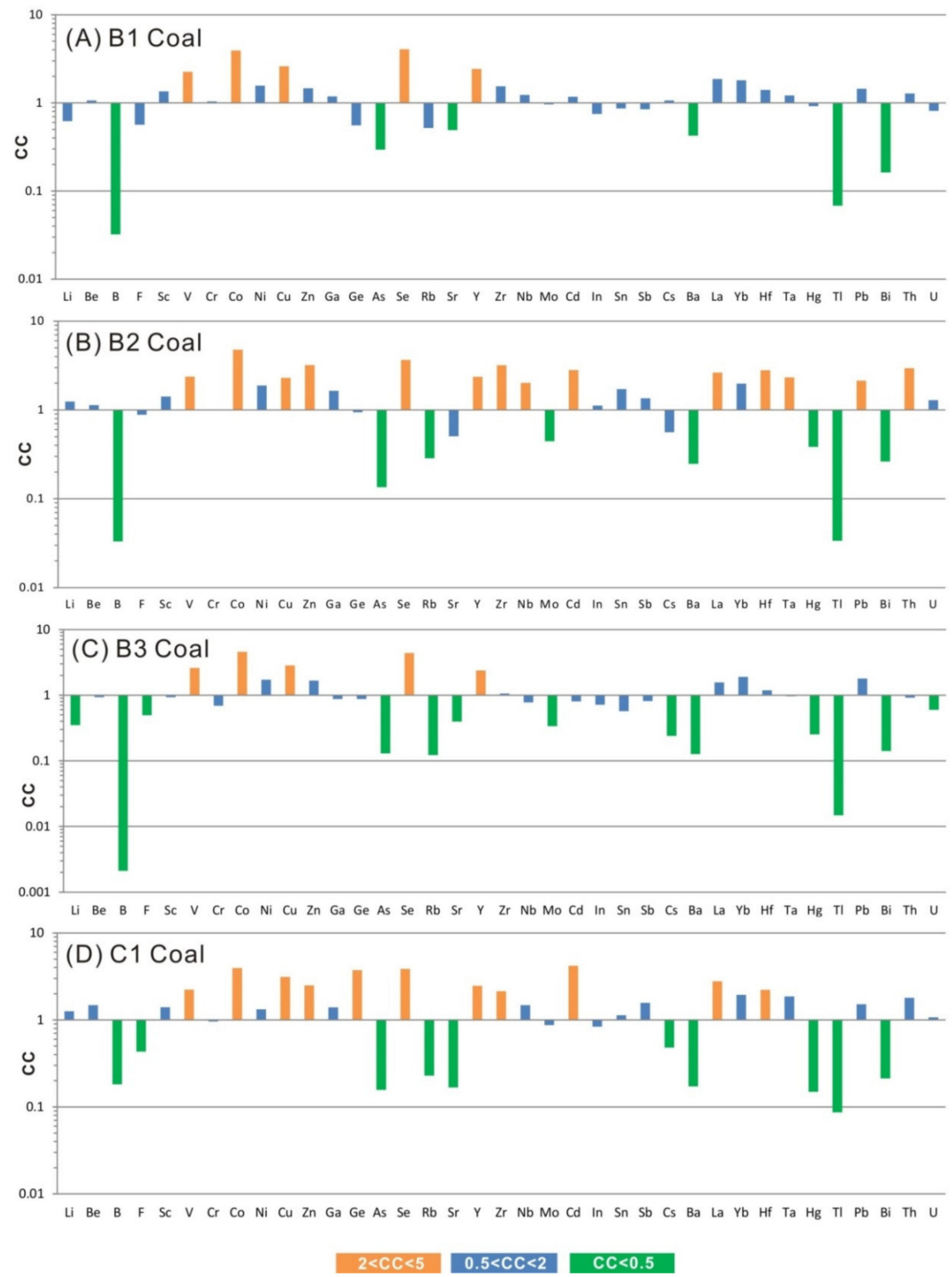

Figure 19. Concentration coefficients (CC) of trace elements in the Bole and Laibin coals, normalized to average trace element concentrations of world hard coals from Ketris and Yudovich (2009) [77]. (A), B1 Coal; (B), B2 Coal; (C), B3 Coal; (D), C1 Coal.

\subsubsection{Rare Earth Elements and Yttrium (REY)}

Based on the classification of Seredin and Dai [8], rare earth elements and yttrium (REY) can be divided into three groups: light ( $\mathrm{La}, \mathrm{Ce}, \mathrm{Pr}, \mathrm{Nd}$, and $\mathrm{Sm}$ ), medium (Eu, Gd, Tb, $\mathrm{Dy}$, and $\mathrm{Y}$ ), and heavy (Ho, Er, Tm, Yb, and Lu) REY. Normalized to the upper continental crust concentrations (UCC) [87], three enrichment patterns of REY in coal, partings, and roof and floor strata of coal seams are identified as light-type $\left(\mathrm{La}_{N} / \mathrm{Lu}_{N}>1\right)$, medium-type $\left(\mathrm{La}_{N} / \mathrm{Sm}_{N}<1, \mathrm{Gd}_{N} / \mathrm{Lu}_{N}>1\right)$, and heavy-type $\left(\mathrm{La}_{N} / \mathrm{Lu}_{N}>1\right)[8]$.

The weighted average concentration of REY in the B1, B2, and B3 layers and C1 Coal are $133,173,113$, and $179 \mu \mathrm{g} / \mathrm{g}$, respectively (Table 4), higher than the average value for world hard coals $(68.6 \mu \mathrm{g} / \mathrm{g})$ [81].

The REY patterns in the Bole and Laibin coal samples are dominated by medium-type or, in some cases, medium-type and heavy-type enrichments, and can be approximately classified into three groups (Figure 20): the first group is characterized by a weak Eu negative anomaly, the light, medium, and heavy REY in these samples are weakly fractionated relative to the UCC, with the exception of samples B1-4 and, especially, B3-4, which have 
a heavy-type enrichment (Figure 20A,B). Sample B3-4 is also characterized by a clear Eu positive anomaly. In particular, sample B3-4 has the highest heavy REY concentration among all the coal samples. The second group, including six coal samples, is characterized by a clear Eu negative anomaly and a medium-type enrichment (Figure 20C,D). The REY of the third group is characterized by a Gd-maximum anomaly, except C1-13 and C1-14 that have Eu-maximum (Figure 20E,F). Cerium in the coal samples shows only slight or no anomalies.
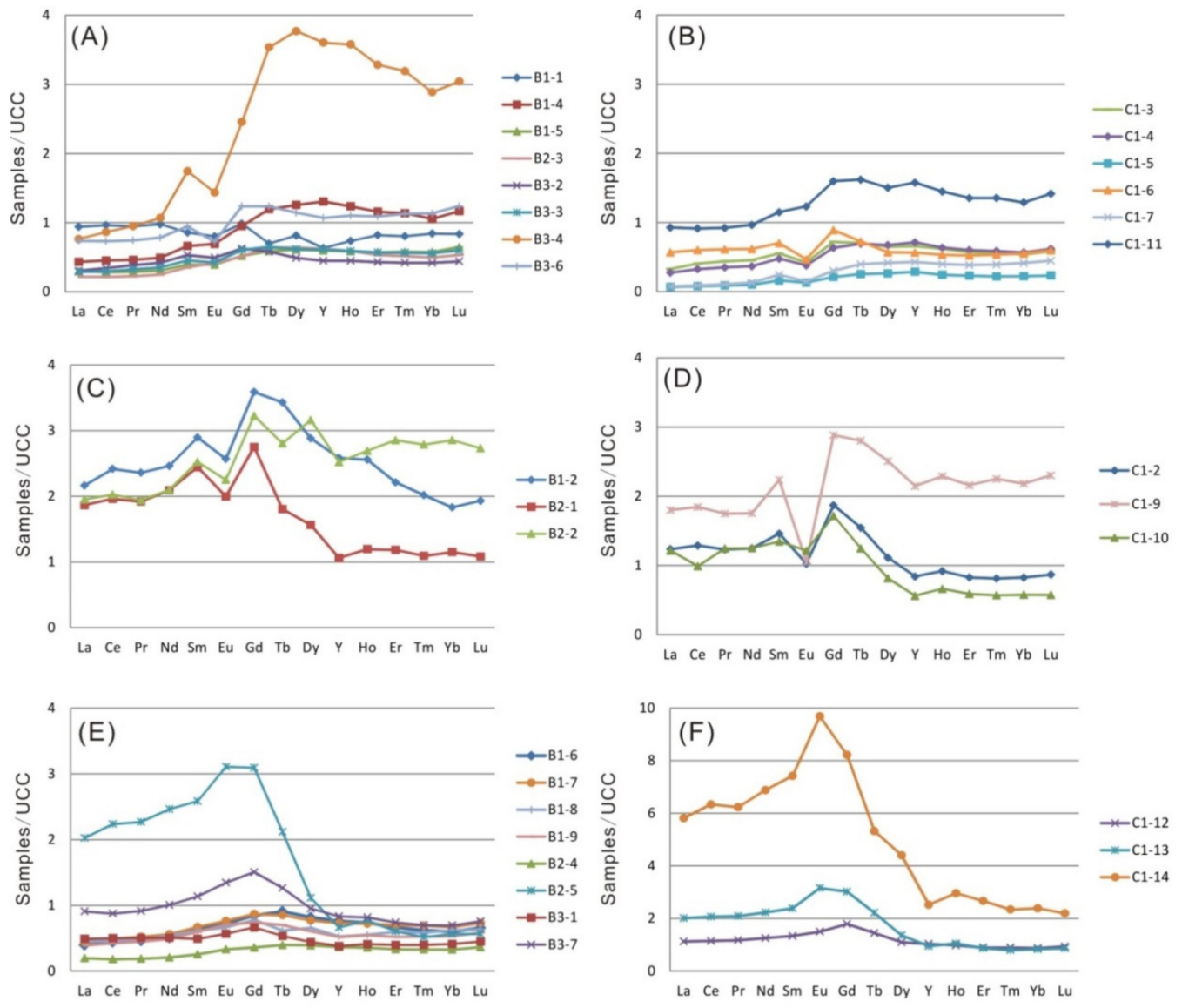

Figure 20. Distribution patterns of rare earth elements and yttrium in the coal samples. (A,B), Samples in the first group characterized by a weak Eu negative anomaly. (C,D), Samples in the second group characterized by a clear Eu negative anomaly. (E,F), Samples in the third group characterized by a Gd-maximum anomaly, except C1-13 and C1-14 that have Eu-maximum. REY are normalized to an Upper Continental Crust (UCC) [87].

The REY distribution patterns in the four partings are characterized by distinctive negative $\mathrm{Eu}$ anomalies. Samples C1-1t and C1-8p are enriched in medium-REY whereas B1-3p and B3-5p are enriched in heavy-REY (Figure 21A). The floor samples have similar REY distribution patterns with positive Eu and negative $Y$ anomalies (Figure 21B).

The two roof samples (B1-r and B3-r) are characterized by slight enrichment of lightREY and weak positive Eu anomalies (Figure 21C). However, the roof strata of the B2 coal have a heavy-type REY enrichment and negative Eu anomaly (Figure 21D). Two types of REY distribution patterns were observed in the roof samples of the $\mathrm{C} 1$ coal: samples $\mathrm{C} 1-1 \mathrm{r}$, C1-2r, and C1-6r (Figure 21E) have a medium-type enrichment and positive Eu anomalies. Other samples are characterized by L-type enrichment (Figure 21F). 

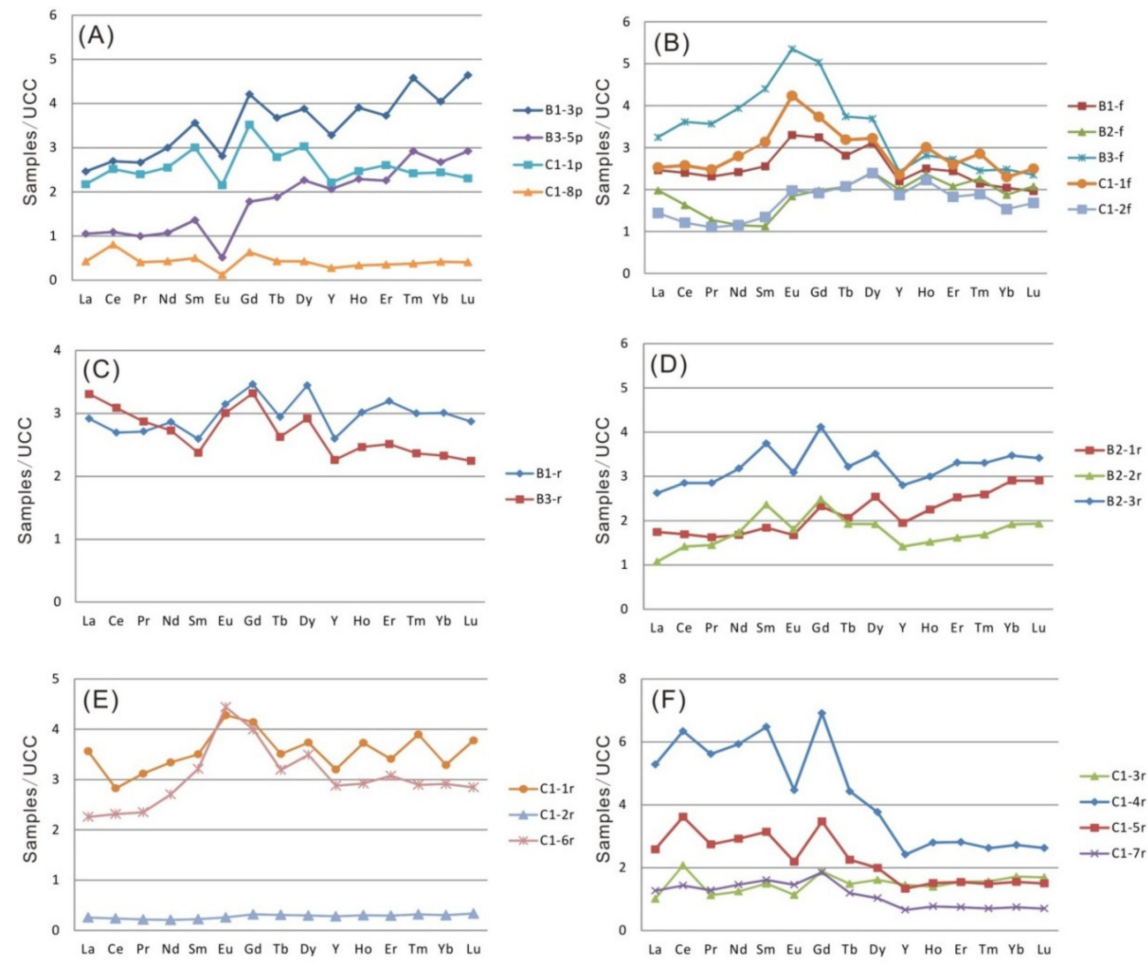

Figure 21. REY distribution patterns in the roof, floor, and parting strata of B1, B2, B3, and C1 coals. REY are normalized to an Upper Continental Crust (UCC) [87]. (A), parting samples in C1 Coal and B1 and B3 layers. (B), Floor samples of C1 Coal and B1, B2, and B3 layers. (C), Roof samples of B1 and B3 layers. (D), Roof samples of the B2 layer. (E,F), Roof samples of C1 Coal.

\subsubsection{Variations of Trace Elements through the Coal Seam Sections}

The variations of elevated concentrations of $\mathrm{V}, \mathrm{Co}, \mathrm{Cu}$, and $\mathrm{REY}$, and, to a lesser extent, $\mathrm{Se}$, showed similar trends in each section of C1 Coal, and B1, B2, and B3 layers (Figures 22 and 23), indicating similar sources. The concentrations of $\mathrm{V}, \mathrm{Co}, \mathrm{Cu}$, and $\mathrm{Se}$ in the tonsteins are much lower than those in the coal, roof, and floor strata, indicating different sources, i.e., felsic magma for the former and mafic Kangdian Upland for the latter. The variations of trace elements and their origins in coal seams present in this study are similar to those of a number of coal seams containing tonsteins in Southwestern China $[12,13,24,47,78,80]$.
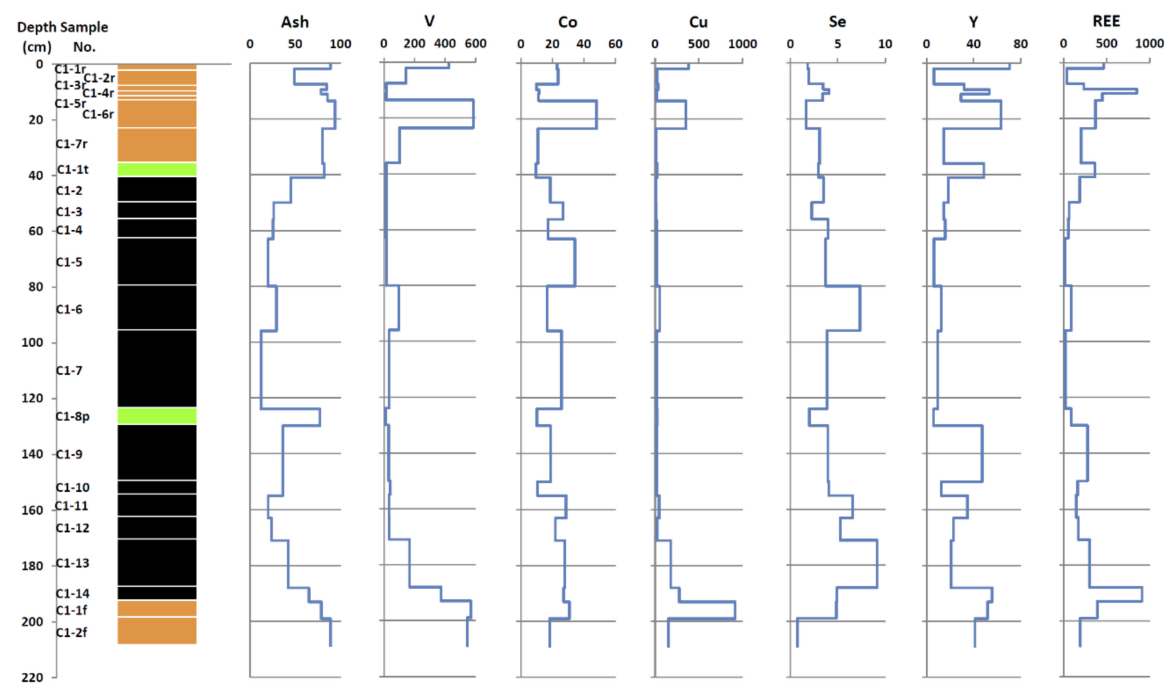

Figure 22. Variations of ash yields (\%) and concentrations $(\mu \mathrm{g} / \mathrm{g})$ of $\mathrm{V}, \mathrm{Co}, \mathrm{Cu}, \mathrm{Se}, \mathrm{Y}$, and REE through a $\mathrm{C} 1$ coal seam. 


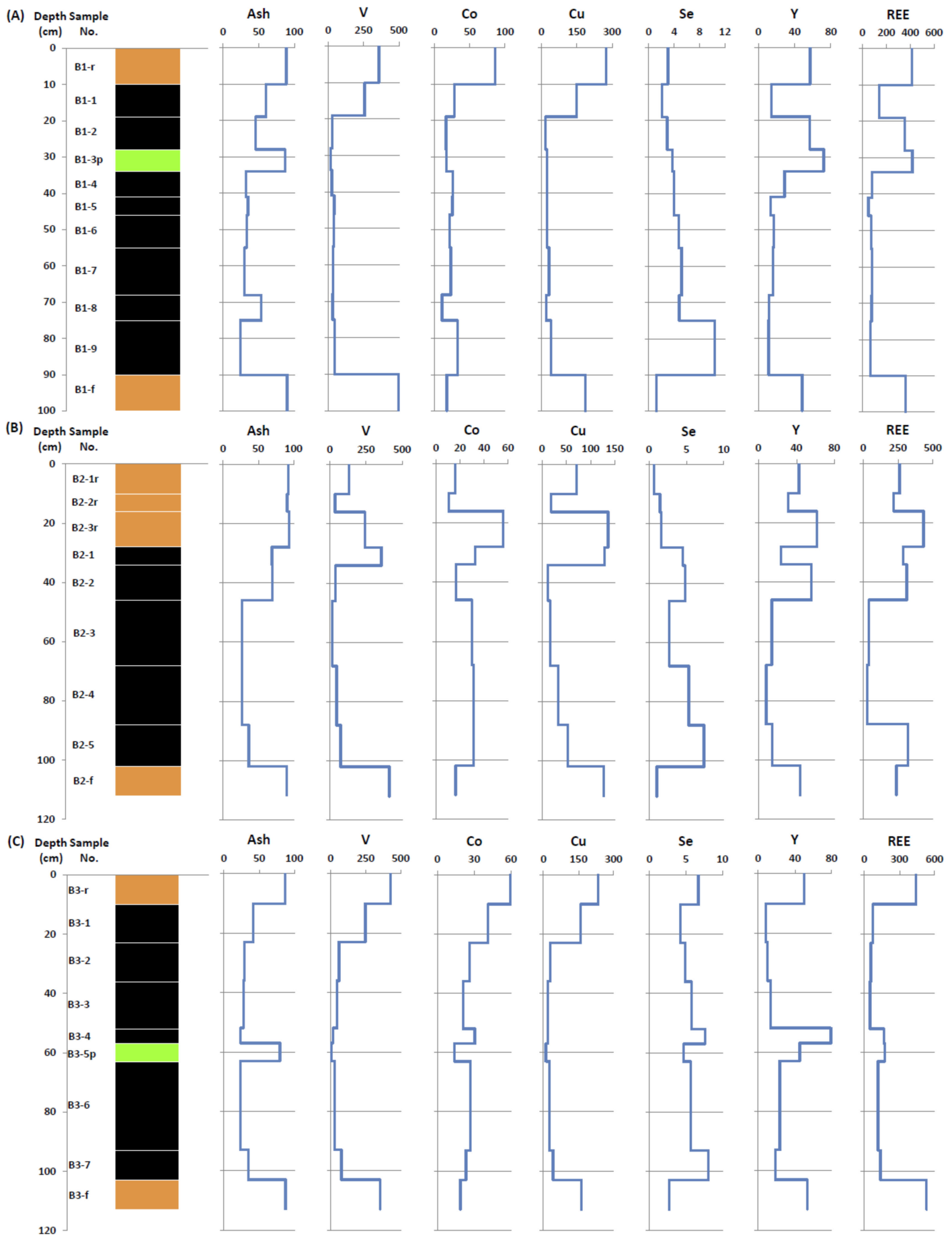

Figure 23. Variations of ash yields (\%) and concentrations $(\mu \mathrm{g} / \mathrm{g})$ of $\mathrm{V}, \mathrm{Co}, \mathrm{Cu}, \mathrm{Se}, \mathrm{Y}$, and REE through B1, B2, and B2 layers. The legend is the same as that in Figure 22. (A), B1 layer. (B), B2 layer. (C), B3 layer.

\section{Discussion}

\subsection{Input of Altered Volcanic Ashes in the Coal-Bearing Strata}

Volcanogenic claystones in the coal seams are referred to as tonsteins, bentonites, or K-bentonites, respectively, when kaolinite, smectite, or mixed-layer I/S exceed 50\% of the clay mineral assemblages, respectively $[18,88]$. Southwest China is one of the areas of the world with the most frequent and largest eruptions of volcanic ash during the Late Permian [22,89]. The Late Permian tonsteins, including as many as 30-60 layers in the 
Xuanwei and Longtan formations, are widely distributed over areas up to $67,000 \mathrm{~km}^{2}$ in Western Guizhou and Eastern Yunnan provinces of Southwestern China [75].

The C1 (B1, B2, and B3) coal seam of this study from both the Bole and Laibin mines contains four partings, all of which have been derived from felsic volcanic ash and, therefore, are identified as tonsteins based on the following evidence.

(1) The partings are all thin $(5-6 \mathrm{~cm})$ but laterally continuous throughout the Laibin and Bole coal mines and have a sharp contact with the enclosing coal seam, in which both have general macroscopic characteristics of tonsteins $[17,18]$.

(2) Due to the high proportions of kaolinite $(>50 \%)$ and its mode of occurrence, the partings are referred to as tonsteins rather than K-bentonites even though sample B1-3p contains a high proportion of mixed layer I/S (Table 2). The sample B3-5p can be further classified as a Graupen-tonstein due to the spheroidal aggregates of fine-grained kaolinite (Figure 11D,E). Kaolinite found as vermicular (Figure 11A,E) or tabular (Figure 11C) shape may be formed by alteration of volcanic glass. The vermicular kaolinite is generally considered as evidence for a volcanic origin of claystone within coal seams $[12,18,71,74,90]$. In addition, the kaolinite-chlorite pseudomorphs after biotite resulted from alteration in the peat swamp [10,18,91].

(3) High-temperature quartz in the form of angular grains (Figure 12A-C) and corroded quartz crystals with jagged edges or cavities (Figures 11B and 12D) are direct evidence for its derivation from felsic or felsic-intermediate volcanic ashes [12,17]. Angular grains of quartz (Figure 12A) may also be considered as magmatic in origin [75].

(4) Anatase is generally considered a secondary mineral in tonsteins and is likely derived from the break-down of volcanic ash material $[74,92,93]$. Anatase crystals with embayments or replacing volcanic glasses (Figure 13A-C) appear to represent alteration products of Ti-rich volcanic glass.

(5) A small proportion of zircon, apatite, and monazite have been identified in the partings under the SEM. Their preserved subhedral to euhedral crystals (Figures 11G, $13 \mathrm{~A}, \mathrm{~F}$, and $14 \mathrm{~A}-\mathrm{D})$ are indicative of volcanic input $[10,17,91,94,95]$. Monazite, if observed in tonsteins, is usually igneous in origin and generally derived from felsic volcanic ashes [10].

(6) The concentrations of $\mathrm{Sc}, \mathrm{Ti}, \mathrm{V}, \mathrm{Cr}, \mathrm{Co}, \mathrm{Ni}, \mathrm{Cu}$, and $\mathrm{Zn}$ are not enriched in the studied partings (Table 4) but are generally elevated in the Late Permian coals of Southwestern China and their roof and floor strata. This indicates that these elements in the four partings have a different (volcanic) origin and have not resulted from erosion of the Kangdian Upland, which is the major sediment source for most of the Late Permian coals in the region [96].

The $\mathrm{Al}_{2} \mathrm{O}_{3} / \mathrm{TiO}_{2}$ ratio is relatively stable during surficial weathering, hydrothermal alteration, and volcanic processes $[47,97,98]$ and, therefore, it can be used as a useful provenance indicator for sedimentary rocks (including coal), and for classification of altered volcanic ash $[10,99]$. Typical $\mathrm{Al}_{2} \mathrm{O}_{3} / \mathrm{TiO}_{2}$ ratios for sediments or tonsteins derived from mafic, intermediate, and felsic igneous rocks are 3-8, 8-21, and 21-70, respectively $[10,99]$. The $\mathrm{Al}_{2} \mathrm{O}_{3} / \mathrm{TiO}_{2}$ ratios of the four studied partings range from 54.8 to 179 (Table 3, Figure 24), which, along with the distinct negative Eu anomaly of the REY distribution patterns (Figure 21A), indicates a felsic origin. These tonsteins may be correlated with other Upper Permian volcaniclastic rocks of South China, for which their origin is still uncertain [100-102]. 


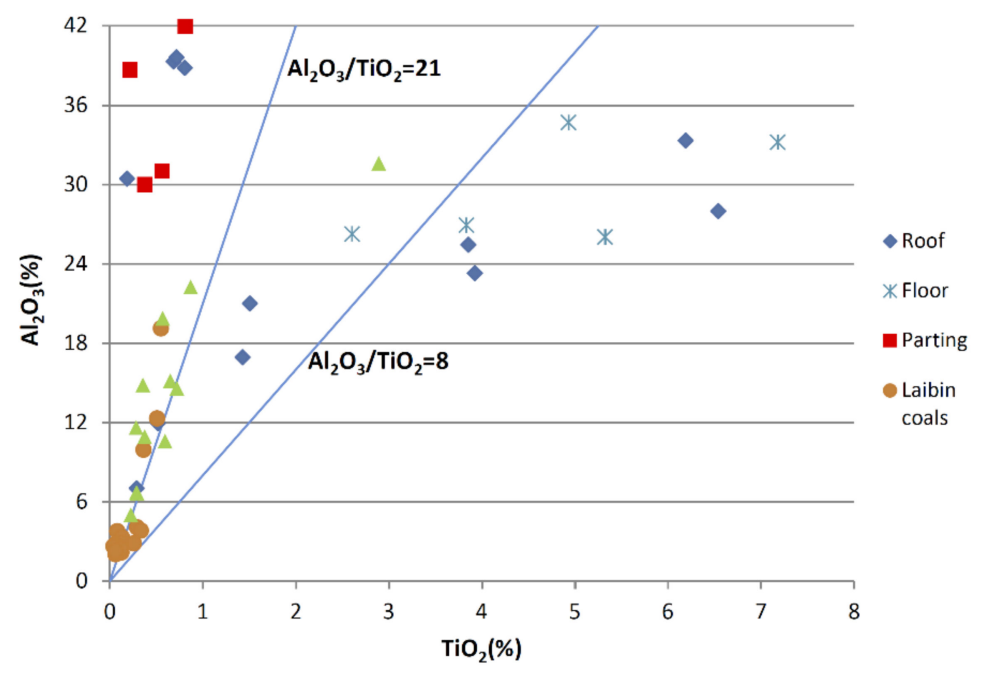

Figure 24. Plot of $\mathrm{TiO}_{2}$ vs. $\mathrm{Al}_{2} \mathrm{O}_{3}$ for coal plies, partings, roof, and floor samples from the Bole and Laibin Mines.

The floor (sample C1-2f) of the Bole mine is identified as a tuffaceous claystone derived from altered mafic volcanic ash rather than water-borne detritus from terrigenous regions, as evidenced by the cryptocrystalline kaolinite with no sedimentary layering observed (Figure 16A) and the large amount of anatase debris disseminated in the matrix (Figure 16B-F). The anatase may have been derived from volcanic ashes, as evidenced by well-developed crystals or the crystals with high-temperature cracks and embayments [21]. Meanwhile some anatase grains show the skeletal/colloidal structure, suggesting intense alteration even though anatase is usually found unaltered in mafic volcanic ash [12,20,21]. The REY enrichment pattern of sample C1-2f, characterized by M-type and H-type enrichment and weak positive Eu anomaly (Figure 21B), differs slightly from those of low-Ti basalts and are more similar to the spidergrams of high-Ti basalts (Figure 25) [103]. The enrichment of heavy REY in the sample C1-2f was likely due to the influx of hydrothermal solutions [8]. The lower Eu anomaly in sample C1-2f sample may be explained by clay alteration of feldspar, which is commonly the main carrier of Eu in magmatic rocks. A very high $\mathrm{Ti} / \mathrm{Y}$ ratio (about 900) for sample C1-2f claystone indicates a high-Ti basalt as the source rock as well [103]. Such a basaltic origin is also supported by higher concentrations of $\mathrm{Zr}, \mathrm{Nb}, \mathrm{V}, \mathrm{Co}, \mathrm{Cu}, \mathrm{Zn}$, and a low $\mathrm{Al}_{2} \mathrm{O}_{3} / \mathrm{TiO}_{2}$ value (4.62, Table 3) for the sample.

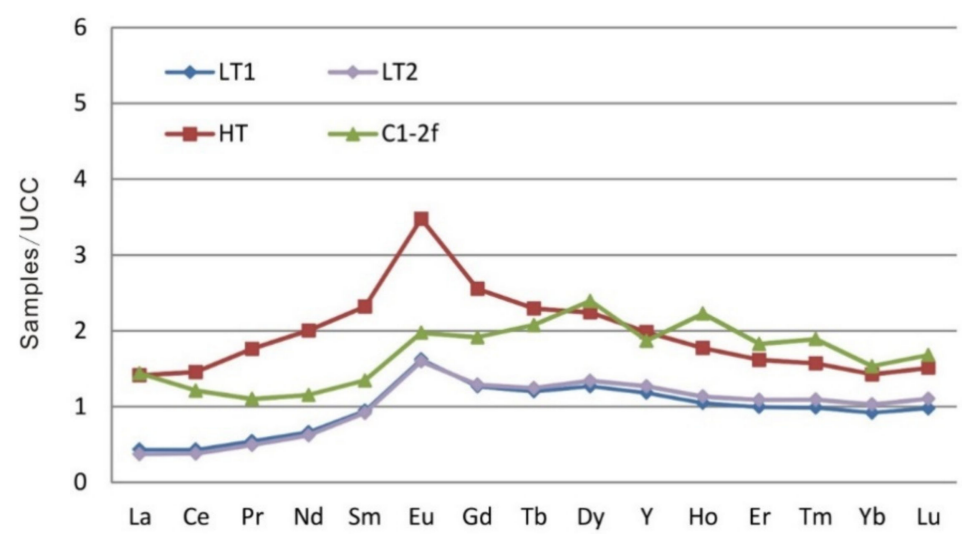

Figure 25. REY distribution patterns normalized to the Upper Continental Crust (UCC) [87] for the C1-2f sample and high-Ti and low-Ti alkali basalts of the Emeishan Province (data from Xiao et al. [103]).

The interpretation of the $\mathrm{C} 1-2 \mathrm{f}$ claystone as tuffaceous is not contradictory with the high-Ti basalts, which were mainly erupted in the Emeishan Province some 257-260 Ma 
ago $[39,104]$ because the former was deposited closer to the P-T boundary than the latter. Zhu et al. [105] found a very thick ( 100 m) tuff layer from which zircons gave a laser ablation ICP-MS U-Pb age of $251 \pm 1 \mathrm{Ma}$, close to the suggested depositional age for the studied rocks. These data confirm the suggestion that volcanic activity of the Emeishan Province was continuing throughout the Late Permian $[47,106]$.

The chemical compositions in the tuffaceous floor and tonsteins present in this study are similar to those reported by Dai et al. [12,47] and Zhou et al. [22,23]. Dai et al. [47] have identified three types of tonsteins (silicic, mafic, and alkali) in the Late Permian coal seams in Southwestern China. The alkali and silicic tonsteins are mainly distributed in the early and late stages of the Late Permian, respectively. The mafic tonsteins and tuffs are distributed throughout the late Permian [47]. The three types of tonsteins have different assemblage of elevated trace elements. The mafic tonsteins and tuffs are enriched in Sc, $\mathrm{V}, \mathrm{Cr}, \mathrm{Co}$, and $\mathrm{Ni}$, and the alkali tonsteins are characterized by high contents of $\mathrm{Nb}, \mathrm{Ta}$, $\mathrm{Zr}, \mathrm{Hf}, \mathrm{REY}$, and Ga. The silicic tonsteins contain the lowest amount of REY but have the highest fractionation between light REE and heavy REY. As suggested by Dai et al. [47], tonsteins in the Late Permian coal seams in Southwestern China may be at the periphery of the Emeishan Large Igneous Province and likely resulted from a waning activity of the plume. The three types of tonsteins were derived from different mantle sources that have been subjected to low-degree partial melting, fluid fractionation, and contamination by a lithospheric mantle [47].

\subsection{Origin of Interstratified Berthierine/Chamosite}

Berthierine is a common mineral in modern sediments and sedimentary rocks, and is considered to be typical of marine sediments due to the reducing environment of the seabed and the presence of abundant iron ions [31-33,35]. However, berthierine has also been observed in non-marine low-temperature metamorphic and hydrothermally-altered rocks [107-109], and in coal-bearing strata in Japan and China [20,21,110,111]. In the latter cases, berthierine may replace pre-existing minerals (e.g., kaolinite, siderite, and other Fe-rich phases) [111-113], directly precipitating from some Fe-bearing and Mg-bearing solutions $[65,66,114]$ or results from the dissolution of volcanic fragments when Fe and $\mathrm{Mg}$ are liberated during recrystallization $[21,115,116]$. The coexistence of $\mathrm{B} / \mathrm{C}$ with quartz or calcite (Figure $5 \mathrm{~B}-\mathrm{E}$ ) does not necessarily indicate their genetic relations. However, the intergrowth of $B / C$ and kaolinite (Figure $6 A, B$ ) indicates that $B / C$ was derived from the kaolinite and Fe-rich and $\mathrm{Mg}$-rich hydrothermal solutions, and that the formation mechanism of B/C is similar to that of chamosite reported by Dai et al. [29] and Wang et al. [24]. The relations between B/C and kaolinite in the floor sample (B3-f) also indicates the substitution of the former for the latter (Figure 15C,D).

Berthierine is generally considered relatively stable in low-temperature $\left(<200{ }^{\circ} \mathrm{C}\right)$ reduced environments $[66,109,110,113,117]$. As the temperature increases, it can be transformed into chamosite or occur as an interstratification phase in a certain temperature range. Iijima and Matsumoto [110] proposed that the formation temperature of berthierine in the Paleogene and Late Triassic coals of Japan is $65-150{ }^{\circ} \mathrm{C}$, and its transformation to chamosite occurred at $160^{\circ} \mathrm{C}$. A similar crystallization temperature for berthierine $\left(150^{\circ} \mathrm{C}\right)$ was also reported by Rivas-Sanchez et al. [117]. Based on the ratio of mixed layer I/S and the occurrence of berthierine, Zhao et al. [118] inferred that the diagenesis temperature of polymetallic mineralized beds in Eastern Yunnan is $100-160{ }^{\circ} \mathrm{C}$, sometimes reaching $180^{\circ} \mathrm{C}$. Ryan and Hillier [66] showed that interstratified berthierine/chamosite was stable in the range of temperatures between 90 and $200{ }^{\circ} \mathrm{C}$ in Late Jurassic sandstones, U.S. Gulf Coast. Therefore, the formation of $\mathrm{B} / \mathrm{C}$ in the samples investigated in this study was most likely under a low-temperature regime (i.e., $<200{ }^{\circ} \mathrm{C}$ ).

Moreover, the REE-phosphates (rhabdophane and florencite) observed in the coals and non-coal samples of the present study (Figure 10C,D, and Figure 15F) may also be related to low-temperature solutions [119-121]. It should be mentioned, however, that the suggested temperature of authigenic mineralization corresponds to both ascending-hydrothermal 
and heated-meteoric solutions, for which the transitional field is between $25-50{ }^{\circ} \mathrm{C}$ and $200{ }^{\circ} \mathrm{C}$ [122]. Therefore, this study does not answer the question regarding the sources of the studied authigenic mineralization regarding whether they were from a deeper source or related to weathering and other near-surface processes. It is most likely that both deep and near-surface processes have complexly influenced the Late Permian coal basins of SW China, as suggested by Dai et al. [123].

\subsection{Origin of Quartz and Other Minerals}

Quartz of authigenic origin is common in the Late Permian coals of Southwestern China, especially Eastern Yunnan Province. It is considered that the quartz was derived from silica-containing solutions originating from the weathering of volcanic rocks in the Kangdian Upland or from post-depositional silica-rich fluids [12,29]. The occurrence modes of quartz (Figure 8 ) in the studied coal samples indicates that the silica-rich fluid input was either from the sediment-source region or from fluid sources during peat accumulation or before peat compaction. The authigenic quartz in the samples may also be derived from desilicification of the volcanic ashes. Soluble Si from the volcanic ashes may then have re-precipitated in the pores of the underlying peat $[1,124]$. Desilicification of the volcanic ashes in the peat swamp has been commonly observed in many coalfields $[10,18]$. However, it is not necessary for hydrothermal solutions to take part in the desilicification process as the process can occur during the syngentic (peat deposition) or diagentic (rank advance) stages.

The modes of occurrence of framboidal pyrite within collodetrinite (Figure 8) show that the mineral was formed at syngenetic and/or early diagenetic stages during or shortly after the peat accumulation. Other authigenic minerals, including fracture-filling pyrite (or iron-sulphate minerals) and calcite (Figures 8 and 14), euhedral gypsum in the tonstein (B35p) (Figure 14) and rhabdophane in the floor sample (B3-f) (Figure 15) suggest epigenetic deposition.

\section{Conclusions}

The coals from the No. C1 (B1, B2, and B3) coal seam of the Bole and Laibin mines, Eastern Yunnan, are mainly medium-high ash, low-sulphur bituminous coal. The minerals in the coals are mainly dominated by quartz and interstratified berthierine/chamosite, along with varying proportions of kaolinite, mixed layer I/S, calcite, anatase, pyrite, bassanite, chalcopyrite, and REE-phosphates. Low-temperature solutions are a very important factor responsible for the mineralogical compositions during the diagenetic process. Abundant authigenic quartz is the result of silica-rich solution inputs during peat accumulation or before peat compaction. The coexisting calcite as cell-infillings may have been leached from the Maokou limestones. Interstratified berthierine/chamosite in the coals is largely formed from direct precipitation of Fe-Mg-rich hydrothermal fluids, likely after the formation of quartz. However, berthierine $(\mathrm{B} / \mathrm{C})$ in the floor strata were derived from the interaction of kaolinite with the hydrothermal fluids. In addition, minor minerals including pyrite, anatase, REE-phosphates, chalcopyrite, and gypsum are also derived from multi-stage hydrothermal fluids as indicated by the presence of berthierine (B/C) and REE-phosphates. The diagenetic environment for the formation of the coal seams is suggested to be of a low temperature $\left(<200^{\circ} \mathrm{C}\right)$.

The multi-stage volcanic ash deposition plays another key role in coal formation. Four thin intra-seam claystones (partings) within the coal seams are identified as tonstein layers, mainly evidenced by cryptocrystalline and vermicular kaolinite, along with minor proportions of high-temperature quartz, volcanic zircon, apatite, monazite, and anatase. The tonsteins are likely derived from felsic volcanic ash, which are characterized by high $\mathrm{Al}_{2} \mathrm{O}_{3} / \mathrm{TiO}_{2}$ values (51.6-179) and negative Eu anomalies.

Based on the modes of occurrence of its minerals, higher concentrations of $\mathrm{Zr}, \mathrm{Nb}, \mathrm{V}$, $\mathrm{Co}, \mathrm{Cu}, \mathrm{Zn}$, low $\mathrm{Al}_{2} \mathrm{O}_{3} / \mathrm{TiO}_{2}$ (4.62), and high $\mathrm{Ti} / \mathrm{Y}$ value, as well as the M-type distribution pattern of rare earth elements and the positive Eu anomaly, the floor sample of the Bole 
mine (C1-2f) is identified as a tuffaceous claystone consisting of altered mafic volcanic (high-Ti basalt of the Emeishan large igneous province) rather than detrital materials from sediment source regions.

Author Contributions: X.L. and X.W. collected samples and conducted the determinations of contents of minerals and major-element contents. S.D., L.Z., and V.P.N. were responsible for the analysis of trace-element concentrations and the origin of minerals. I.T.G., D.F., and J.Z. were responsible for the mineralogy investigation using XRD and SEM-EDX. All authors have read and agreed to the published version of the manuscript.

Funding: This research was supported by the National Natural Science Foundation of China [Nos. 91962220, 41702165, and 41672151] and the 111 Project [No. B17042].

Institutional Review Board Statement: Not applicable.

Informed Consent Statement: Not applicable.

Acknowledgments: The authors are grateful to Colin Ward for his careful and constructive comments on the manuscript.

Conflicts of Interest: The authors declare no conflict of interest.

\section{References}

1. Ward, C.R. Analysis and significance of mineral matter in coal seams. Int. J. Coal Geol. 2002, 50, 135-168. [CrossRef]

2. Ward, C.R. Analysis, origin and significance of mineral matter in coal: An updated review. Int. J. Coal Geol. 2016, 165, 1-27. [CrossRef]

3. Finkelman, R.B.; Dai, S.; French, D. The importance of minerals in coal as the hosts of chemical elements. Int. J. Coal Geol. 2019, 212, 103251. [CrossRef]

4. Ren, D. Mineral matters in coal. In Coal Petrology of China; Han, D.X., Ed.; Publishing House of China University of Mining and Technology: Xuzhou, China, 1996; pp. 67-77. (In Chinese)

5. Dai, S.; Ren, D.; Chou, C.L.; Finkelman, R.B.; Seredin, V.V.; Zhou, Y. Geochemistry of trace elements in Chinese coals: A review of abundances, genetic types, impacts on human health, and industrial utilization. Int. J. Coal Geol. 2012, 94, 3-21. [CrossRef]

6. Huang, X.; Gordon, T.; Rom, W.N.; Finkelman, R.B. Interaction of iron and calcium minerals in coals and their roles in coal dust-induced health and environmental problems. Rev. Miner. Geochem. 2006, 64, 153-178. [CrossRef]

7. Seredin, V.V. From coal science to metal production and environmental protection: A new story of success. Int. J. Coal Geol. 2012, 90-91, 1-3. [CrossRef]

8. Seredin, V.V.; Dai, S. Coal deposits as potential alternative sources for lanthanides and yttrium. Int. J. Coal Geol. 2012, 94, 67-93. [CrossRef]

9. Dai, S.; Yan, X.; Ward, C.R.; Hower, J.C.; Zhao, L.; Wang, X.; Zhao, L.; Ren, D.; Finkelman, R.B. Valuable elements In Chinese coals: A review. Int. Geol. Rev. 2018, 60, 590-620. [CrossRef]

10. Dai, S.; Ward, C.R.; Graham, I.T.; French, D.; Hower, J.C.; Zhao, L.; Wang, X. Altered volcanic ashes in coal and coal-bearing sequences: A review of their nature and significance. Earth Sci. Rev. 2017, 175, 44-74. [CrossRef]

11. Ren, D.; Zhao, F.; Dai, S.; Zhang, J.; Luo, K. Geochemistry of Trace Elements in Coal; Science Press: Beijing, China, 2006; p. 556. (In Chinese)

12. Dai, S.; Li, T.; Seredin, V.V.; Ward, C.R.; Hower, J.C.; Zhou, Y.; Zhang, M.; Song, X.; Song, W.; Zhao, C. Origin of minerals and elements in the Late Permian coals, tonsteins, and host rocks of the Xinde Mine, Xuanwei, eastern Yunnan, China. Int. J. Coal Geol. 2014, 121, 53-78. [CrossRef]

13. Dai, S.; Liu, J.; Ward, C.R.; Hower, J.C.; French, D.; Jia, S.; Hood, M.M.; Garrison, T.M. Mineralogical and geochemical compositions of late Permian coals and host rocks from the Guxu coalfield, Sichuan province, China, with emphasis on enrichment of rare metals. Int. J. Coal Geol. 2016, 166, 71-95. [CrossRef]

14. Raymond, R.; Andrejeko, M.J. Mineral. Matter in Peat: Its Occurrence, Form, and Distribution; Report LA9907 OBES; Los Alamos National Laboratory: Los Alamos, NM, USA, 1983; p. 242.

15. Cobb, J.C. Timing and development of mineralized veins during diagenesis in coal beds. In Proceedings of the 9th International Congress on Carboniferous Stratigraphy and Geology, Urbana, IL, USA, 19 May 1979; Cross, A.T., Ed.; Southern Illinois University Press: Carbondale, IL, USA, 1985; Volume 4, pp. 371-376.

16. Burger, K.; Zhou, Y.; Tang, D. Synsedimentary volcanic ash derived illitic tonsteins in Late Permian coal-bearing formations of southwestern China. Int. J. Coal Geol. 1990, 15, 341-356. [CrossRef]

17. Bohor, B.F.; Triplehorn, D.M. Tonsteins: Altered Volcanic-Ash Layers in Coal-Bearing Sequences; Special Paper 285; Geological Society of America: Boulder, CO, USA, 1993; p. 44.

18. Spears, D.A. The origin of tonsteins, an overview, and links with seatearths, fireclays and fragmental clay rocks. Int. J. Coal Geol. 2012, 94, 22-31. [CrossRef] 
19. Dai, S.; Guo, W.; Nechaev, V.P.; French, D.; Ward, C.R.; Spiro, B.F.; Finkelman, R.B. Modes of occurrence and origin of mineral matter in the Palaeogene coal (No. 19-2) from the Hunchun Coalfield, Jilin Province, China. Int. J. Coal Geol. 2018, 189, 94-110. [CrossRef]

20. Zhao, L.; Dai, S.; Graham, I.T.; Li, X.; Zhang, B. New insights into the lowest Xuanwei Formation in eastern Yunnan Province, SW China: Implications for Emeishan large igneous province felsic tuff deposition and the cause of the end-Guadalupian mass extinction. Lithos 2016, 264, 375-391. [CrossRef]

21. Zhao, L.; Dai, S.; Graham, I.T.; Li, X.; Liu, H.; Song, X.; Hower, J.C.; Zhou, Y. Cryptic sediment-hosted critical element mineralization from eastern Yunnan Province, southwestern China: Mineralogy, geochemistry, relationship to Emeishan alkaline magmatism and possible origin. Ore Geol. Rev. 2017, 80, 116-140. [CrossRef]

22. Zhou, Y.; Ren, Y.; Bohor, B.F. Origin and distribution of tonsteins in Late Permian coal seams of southwestern China. Int. J. Coal Geol. 1982, 2, 49-77. [CrossRef]

23. Zhou, Y.; Bohor, B.F.; Ren, Y. Trace element geochemistry of altered volcanic ash layers (tonsteins) in Late Permian coal-bearing formations of eastern Yunnan and western Guizhou Province, China. Int. J. Coal Geol. 2000, 44, 305-324. [CrossRef]

24. Wang, X.; Dai, S.; Chou, C.-L.; Zhang, M.; Wang, J.; Song, X.; Wang, W.; Jiang, Y.; Zhou, Y.; Ren, D. Mineralogy and geochemistry of Late Permian coals from the Taoshuping Mine, Yunnan Province, China: Evidences for the sources of minerals. Int. J. Coal Geol. 2012, 96, 49-59. [CrossRef]

25. Wang, X.; Zhang, M.; Zhang, W.; Wang, J.; Zhou, Y.; Song, X.; Li, T.; Li, X.; Liu, H.; Zhao, L. Occurrence and origins of minerals in mixed-layer illite/smectite-rich coals of the Late Permian age from the Changxing Mine, eastern Yunnan, China. Int. J. Coal Geol. 2012, 102, 26-34. [CrossRef]

26. Large, D.J.; Kelly, S.; Spiro, B.; Tian, L.; Shao, L.; Finkelman, R.; Zhang, M.; Somerfield, C.; Plint, S.; Ali, Y.; et al. Silica-volatile interaction and the geological cause of the Xuan Wei lung cancer epidemic. Environ. Sci. Technol. 2009, 43, 9016-9021. [CrossRef] [PubMed]

27. Tian, L. Coal Combustion Emissions and Lung Cancer in Xuan Wei, China. Ph.D. Thesis, University of California, Berkeley, CA, USA, 2005.

28. Li, J. Fe-Rich Chamosite in Coal and Lung Cancer in Xuan Wei, China. Ph.D. Thesis, University of Hong Kong, Pokfulam, Hong Kong, China, 2019.

29. Dai, S.; Tian, L.; Chou, C.-L.; Zhou, Y.; Zhang, M.; Zhao, L.; Wang, J.; Yang, Z.; Cao, H.; Ren, D. Mineralogical and compositional characteristics of Late Permian coals from an area of high lung cancer rate in XuanWei, Yunnan, China: Occurrence and origin of quartz and chamosite. Int. J. Coal Geol. 2008, 76, 318-327. [CrossRef]

30. Dai, S.; Chou, C.-L. Occurrence and origin of minerals in a chamosite-bearing coal of Late Permian age, Zhaotong, Yunnan, China. Am. Miner. 2007, 92, 1253-1261. [CrossRef]

31. Bhattacharyya, D.P. Origin of berthierine in ironstones. Clay Clay Min. 1983, 31, 173-182. [CrossRef]

32. Van Houten, F.B.; Purucker, M.E. Glauconitic peloids and chamositic ooids-Favorable factors, constraints, and problems. Earth Sci. Rev. 1984, 20, 211-243. [CrossRef]

33. Macquaker, J.H.S.; Taylor, K.G.; Young, T.P.; Curtis, C.D. Sedimentological and geochemical controls on ooidal ironstone and 'bone-bed' formation and some comments on their sequence stratigraphic significance. In Sequence Stratigraphy in British Geology; Hesselbo, S., Parkinson, D.N., Eds.; Geological Society of London Special Publication: London, UK, 1996; Volume 103, pp. 97-107.

34. Boyd, G.A.; Wallace, M.W.; Holdgate, G.R.; Gallagher, S.J. Marine clays and porosity evolution in the Nullawarre Greensand, Otway Basin, southeastern Australia. Pet. Explor. Soc. Aust. 2004, II, 1-16.

35. Huggett, J.M.; Gale, A.S.; McCarty, D. Petrology and palaeoenvironmental significance of authigenic iron-rich clays, carbonates and apatite in the Claiborne Group, Middle Eocene, NE Texas. Sediment. Geol. 2010, 228, 119-139. [CrossRef]

36. China Coal Geology Bureau. Sedimentary Environments and Coal Accumulation of Late Permian Coal Formation in Western Guizhou, Southern Sichuan, and Eastern Yunnan, China; Chongqing University Press: Chongqing, China, 1996; p. 216. (In Chinese)

37. He, B.; Xu, Y.; Huang, X.; Luo, Z.; Shi, Y.; Yang, Q.; Yu, S. Age and duration of the Emeishan Flood volcanism, SW China: Geochemistry and SHRIMP zircon U-Pb dating of silicic ignimbrites, post volcanic Xuanwei Formation and clay tuff at Chaotian section. Earth Planet. Sci. Lett. 2007, 255, 306-323. [CrossRef]

38. He, B.; Xu, Y.; Zhong, Y.; Guan, J. The Guadalupian-Lopingian boundary mudstones at Chaotian (SW China) are clastic rocks rather than acidic tuffs: Implication for a temporal coincidence between the end-Guadalupian mass extinction and the Emeishan volcanism. Lithos 2010, 119, 10-19. [CrossRef]

39. Xu, Y.; Chung, S.; Shao, H.; He, B. Silicic magmas from the Emeishan large igneous province, Southwest China: Petrogenesis and their link with the end-Guadalupian biological crisis. Lithos 2010, 119, 47-60. [CrossRef]

40. Xu, Y.; He, B.; Luo, Z.; Liu, H. Large Igneous Provinces in China and mantle plume: An overview and perspective. Bull. Miner. Pet. Geochem. 2013, 32, 25-39, (In Chinese with English abstract).

41. Shellnutt, J.G.; Denyszyn, S.; Mundil, R. Precise age determination of mafic and felsic intrusive rocks from the Permian Emeishan large igneous province (SW China). Gondwana Res. 2012, 22, 118-126. [CrossRef]

42. Shellnutt, J.G. The Emeishan large igneous province: A synthesis. Geosci. Front. 2014, 5, 369-394. [CrossRef]

43. ASTM International. Standard Test. Method for Moisture in the Analysis Sample of Coal and Coke; ASTM D3173/D3173M-17a; ASTM International: West Conshohocken, PA, USA, 2017. 
44. ASTM International. Standard Test. Method for Ash in the Analysis Sample of Coal and Coke from Coal; ASTM D3174-12; ASTM International: West Conshohocken, PA, USA, 2018.

45. ASTM International. Standard Test. Method for Volatile Matter in the Analysis Sample of Coal and Coke; ASTM D3175-18; ASTM International: West Conshohocken, PA, USA, 2018.

46. ASTM International. Standard Test. Method for Sulfur in the Analysis Sample of Coal and Coke Using High-Temperature Tube Furnace Combustion; ASTM D4239-18e1; ASTM International: West Conshohocken, PA, USA, 2018.

47. Liu, J.; Nechaev, V.P.; Dai, S.; Song, H.; Nechaeva, E.V.; Jiang, Y.; Graham, I.T.; French, D.; Yang, P.; Hower, J.C. Evidence for multiple sources for inorganic components in the Tucheng coal deposit, western Guizhou, China and the lack of critical-elements. Int. J. Coal Geol. 2020, 223, 103468. [CrossRef]

48. ASTM International. Standard Test. Method for Total Fluorine in Coal and Coke by Pyrohydrolytic Extraction and Ion. Selective Electrode or Ion. Chromatograph Methods; ASTM D5987-96; ASTM International: West Conshohocken, PA, USA, 2015.

49. Dai, S.; Wang, X.; Zhou, Y.; Hower, J.C.; Li, D.; Chen, W.; Zhu, X.; Zou, J. Chemical and mineralogical compositions of silicic, mafic, and alkali tonsteins in the late Permian coals from the Songzao Coalfield, Chongqing, Southwest China. Chem. Geol. 2011, 282, 29-44. [CrossRef]

50. Li, X.; Dai, S.; Zhang, W.; Li, T.; Zheng, X.; Chen, W. Determination of As and Se in coal and coal combustion products using closed vessel microwave digestion and collision/reaction cell technology (CCT) of inductively coupled plasma mass spectrometry (ICP-MS). Int. J. Coal Geol. 2014, 124, 1-4. [CrossRef]

51. Dai, S.; Song, W.; Zhao, L.; Li, X.; Hower, J.C.; Ward, C.R.; Wang, P.; Li, T.; Zheng, X.; Seredin, V.V.; et al. Determination of boron in coal using closed-vessel microwave digestion and inductively coupled plasma mass spectrometry (ICP-MS). Energy Fuels 2014, 28, 4517-4522. [CrossRef]

52. ASTM International. Test. Method for Microscopical Determination of the Vitrinite Reflectance of Coal; ASTM D2798-11a; ASTM International: West Conshohocken, PA, USA, 2011.

53. Ward, C.R.; Spears, D.A.; Booth, C.A.; Staton, I.; Gurba, L.W. Mineral matter and trace elements in coals of the Gunnedah Basin, New South Wales, Australia. Int. J. Coal Geol. 1999, 40, 281-308. [CrossRef]

54. Ward, C.R.; Matulis, C.E.; Taylor, J.C.; Dale, L.S. Quantification of mineral matter in the Argonne Premium coals using interactive Rietveld-based X-ray diffraction. Int. J. Coal Geol. 2001, 46, 67-82. [CrossRef]

55. Ruan, C.-D.; Ward, C.R. Quantitative X-ray powder diffraction analysis of clay minerals in Australian coals using Rietveld methods. Appl. Clay Sci. 2002, 21, 227-240. [CrossRef]

56. ASTM International. Standard Classification of Coals by Rank; ASTM D388-12; ASTM International: West Conshohocken, PA, USA, 2012.

57. Standardization Administration of the People's Republic of China. Classification for Quality of Coal. Part. 1: Ash, 2010; Chinese Standard GB/T 15224, 1-2010; Standardization Administration of the People's Republic of China: Beijing, China, 2010. (In Chinese)

58. Committee on Sustainable Energy; Committee on Energy. Working Party on Coal; Committee on Sustainable Energy. International Classification of in-Seam Coals; Document ENERGY/1998/19; United Nations: New York, NY, USA; Geneva, Switzerland, 1998.

59. Chou, C.L. Sulfur in coals: A review of geochemistry and origins. Int. J. Coal Geol. 2012, 100, 1-13. [CrossRef]

60. Brindley, G.W. Chemical compositions of berthierines-A review. Clay Clay Min. 1982, 30, 153-155. [CrossRef]

61. Toth, T.A.; Fritz, S.J. An Fe-berthierine from a cretaceous laterite: Part I. Characterization. Clays Clay Min. 1997, 45, 564-579. [CrossRef]

62. Ahn, J.H.; Peacor, D.R. Transmission electron microscopic study of diagenetic chlorite in Gulf Coast argillaceous sediments. Clays Clay Min. 1985, 33, 228-236. [CrossRef]

63. Reynolds, R.C. Mixed-layer chlorite minerals. In Reviews in Mineralogy; Bailey, S.W., Ed.; Mineralogical Society of America: Washington, DC, USA, 1988; Volume 19, pp. 601-629.

64. Walker, J.R. Structural variations in chlorite and illite in a diagenetic sequence from the Imperial Valley, California. Clays Clay Min. 1990, 38, 315-321. [CrossRef]

65. Hillier, S.; Velde, B. Chlorite interstratified with a 7A mineral: An example from offshore Norway and possible implications for the interpretation of the composition of diagenetic chlorites. Clay Min. 1992, 27, 475-486. [CrossRef]

66. Ryan, P.C.; Reynolds, R.C. The origin and diagenesis of grain-coating serpentine-chlorite in Tuscaloosa Formation sandstone, U.S. Gulf Coast. Am. Miner. 1996, 81, 213-225. [CrossRef]

67. Ryan, P.C.; Hillier, S. Berthierine/chamosite, corrensite, and discrete chlorite from evolved verdine and evaporite-associated facies in the Jurassic Sundance Formation, Wyoming. Am. Miner. 2002, 87, 1607-1615. [CrossRef]

68. Reynolds, R.C.; Distefano, M.P.; Lahann, R.W. Randomly interstratified serpentine/chlorite: Its detection and quantification by X-ray diffraction methods. Clays Clay Miner. 1992, 40, 262-267. [CrossRef]

69. Frazer, F.W.; Belcher, C.B. Quantitative determination of the mineral-matter content of coal by a radio frequency-oxidation technique. Fuel 1973, 52, 41-46. [CrossRef]

70. Permana, A.; Ward, C.R.; Li, Z.; Gurba, L.W. Distribution and origin of minerals in high-rank coals of the South Walker Creek area, Bowen Basin, Australia. Int. J. Coal Geol. 2013, 116-167, 185-207. [CrossRef]

71. Zhao, L.; Ward, C.R.; French, D.; Graham, I.T. Mineralogical composition of Late Permian coal seams in the Songzao Coalfield, southwestern China. Int. J. Coal Geol. 2013, 116-117, 208-226. [CrossRef] 
72. Susilawati, R.; Ward, C.R. Metamorphism of mineral matter in coal from the Bukit Asam deposit, south Sumatra, Indonesia. Int. J. Coal Geol. 2006, 68, 171-195. [CrossRef]

73. Altaner, S.P.; Hower, J.; Whitney, G.; Aronson, J.L. Model for K-bentonite formation: Evidence from zoned K-bentonites in the disturbed belt, Montana. Geology 1984, 12, 412-415. [CrossRef]

74. Ruppert, L.F.; Moore, T.A. Differentiation of volcanic ash-fall and water-borne detrital layers in the Eocene Senakin coal bed, Tanjung Formation, Indonesia. Org. Geochem. 1993, 20, 233-247. [CrossRef]

75. Zhou, Y.; Ren, Y. Origin and geological significance of tonsteins in the Late Permian coals from eastern Yunnan, China. Yunnan Geol. 1983, 2, 38-46, (In Chinese with English abstract).

76. Pearson, D.E.; Kwong, J. Mineral matter as a measure of oxidation of a coking coal. Fuel 1979, 58, 63-66. [CrossRef]

77. Rao, C.P.; Gluskoter, H.J. Occurrence and distribution of minerals in Illinois coals. Ill. State Geol. Surv. 1973, 56, 1-60.

78. Staub, J.R.; Cohen, A.D. Kaolinite-enrichment beneath coals; a modern analog, Snuggedy Swamp, South Carolina. J. Sediment. Res. 1978, 48, 203-210.

79. Dai, S.; Xie, P.; French, D.; Ward, C.R.; Graham, I.T.; Yan, X.; Guo, W. The occurrence of buddingtonite in super-high-organicsulphur coals from the Yishan Coalfield, Guangxi, southern China. Int. J. Coal Geol. 2018, 195, 347-361. [CrossRef]

80. Dai, S.; Zou, J.H.; Jiang, Y.; Ward, C.R.; Wang, X.; Li, T.; Xue, W.; Liu, S.; Tian, H.; Sun, X.; et al. Mineralogical and geochemical compositions of the Pennsylvanian coal in the Adaohai Mine, Daqingshan Coalfield, Inner Mongolia, China: Modes of occurrence and origin of diaspore, gorceixite, and ammonian illite. Int. J. Coal Geol. 2012, 94, 250-270. [CrossRef]

81. Ketris, M.P.; Yudovich, Y.E. Estimations of Clarkes for carbonaceous biolithes: World average for trace element contents in black shales and coals. Int. J. Coal Geol. 2009, 78, 135-148. [CrossRef]

82. Dai, S.; Seredin, V.V.; Ward, C.R.; Hower, J.C.; Xing, Y.; Zhang, W.; Song, W.; Wang, P. Enrichment of U-Se-Mo-Re-V in coals preserved within marine carbonate successions: Geochemical and mineralogical data from the Late Permian Guiding Coalfield, Guizhou, China. Min. Depos. 2015, 50, 159-186. [CrossRef]

83. Goodarzi, F.; Swaine, D.J. The influence of geological factors on the concentration of boron in Australian and Canadian coals. Chem. Geol. 1994, 118, 301-318. [CrossRef]

84. Dai, S.; Luo, Y.; Seredin, V.V.; Ward, C.R.; Hower, J.C.; Zhao, L.; Liu, S.; Zhao, C.; Tian, H.; Zou, J. Revisiting the late Permian coal from the Huayingshan, Sichuan, southwestern China: Enrichment and occurrence modes of minerals and trace elements. Int. J. Coal Geol. 2014, 122, 110-128. [CrossRef]

85. Zhuang, X.; Su, S.; Xiao, M.; Li, J.; Alastuey, A.; Querol, X. Mineralogy and geochemistry of the Late Permian coals in the Huayingshan coal-bearing area, Sichuan Province, China. Int. J. Coal Geol. 2012, 94, 271-282. [CrossRef]

86. Grigoriev, N.A. Chemical Element Distribution in the Upper Continental Crust; UBRAS: Ekaterinburg, Russia, 2009; p. 382. (In Russian)

87. Taylor, S.R.; McLennan, S.M. The Continental Crust: Its Composition and Evolution; Blackwell: Oxford, UK, $1985 ;$ p. 312.

88. Lyons, P.C.; Spears, D.A.; Outerbridge, W.F.; Congdon, R.D.; Evans, H.T. Euramerican tonsteins: Overview, magmatic origin, and depositional-tectonic implications. Palaeogeogr. Palaeoclim. Palaeoecol. 1994, 106, 113-134. [CrossRef]

89. Zhou, Y.; Burger, K.; Tang, D. A new development of research on the tonsteins (clay rock partings) in Late Permian coal measures, Southwest China. Yunnan Geol. 1988, 7, 213-228, (In Chinese with English abstract).

90. Spears, D.A. The mineralogy of the Stafford tonstein. P. Yorks. Geol. Soc. 1971, 38, 497-516. [CrossRef]

91. Zhao, L.; Ward, C.R.; French, D.; Graham, I.T. Mineralogy of the volcanic influenced Great Northern coal seam in the Sydney Basin, Australia. Int. J. Coal Geol. 2012, 94, 94-110. [CrossRef]

92. Spears, D.A.; Kanaris-Sotiriou, R. A geochemical and mineralogical investigation of some British and other European tonsteins. Sedimentology 1979, 26, 407-425. [CrossRef]

93. Triplehorn, D.M.; Stanton, R.W.; Ruppert, L.F.; Crowley, S.S. Volcanic ash dispersed in the Wyodak-Anderson coal bed, Powder River Basin, Wyoming. Org. Geochem. 1991, 17, 567-575. [CrossRef]

94. Hower, J.C.; Ruppert, L.F.; Eble, C.F. Lanthanide, yttrium, and zirconium anomalies in the fire clay coal bed, eastern Kentucky. Int. J. Coal Geol. 1999, 39, 141-153. [CrossRef]

95. Zhou, Y.; Ren, Y.; Tang, D.; Bohor, B. Characteristics of zircons from volcanic ash derived tonsteins in Late Permian coal fields of eastern Yunnan, China. Int. J. Coal Geol. 1994, 25, 243-264. [CrossRef]

96. He, B.; Xu, Y.; Wang, Y.; Luo, Z. Sedimentation and lithofacies paleogeography in Southwestern China before and after the Emeishan flood volcanism: New Insights into surface response to mantle plume activity. J. Geol. 2006, 114, 17-132. [CrossRef]

97. Finlow-Bates, T.; Stumpfl, E.F. The behaviour of so-called immobile elements in hydrothermally altered rocks associated with volcanogenic submarine-exhalative ore deposits. Min. Depos. 1981, 16, 319-328. [CrossRef]

98. Zhou, Y. The synsedimentary alkalinity-volcanic ash derived tonsteins of Early Longtan age in south-western China. Coal Geol. Explor. 1999, 27, 5-9, (In Chinese with English abstract).

99. Hayashi, K.-I.; Fujisawa, H.; Holland, H.D.; Ohmoto, H. Geochemistry of 1.9 Ga sedimentary rocks from northeastern Labrador, Canada. Geochim. Cosmochim. Acta 1997, 61, 4115-4137. [CrossRef]

100. Isozaki, Y.; Yao, J.; Matsuda, T.; Sakai, H.; Ji, Z.; Shimizu, N.; Kobayashi, N.; Kawahata, H.; Nishi, H.; Takano, M.; et al. Stratigraphy of the Middle-Upper Permian and Lowermost Triassic at Chaotian, Sichuan, China Record of Late Permian double mass extinction event. Proc. Jpn. Acad. B 2004, 80, 10-16. [CrossRef] 
101. He, B.; Zhong, Y.; Xu, Y.; Li, X. Triggers of Permo-Triassic boundary mass extinction in South China: The Siberian Traps or Paleo-Tethys ignimbrite flare-up? Lithos 2014, 204, 258-267. [CrossRef]

102. Liao, Z.; Hu, W.; Cao, J.; Wang, X.; Yao, S.; Wu, H.; Wan, Y. Heterogeneous volcanism across the Permian-Triassic Boundary in South China and implications for the Latest Permian Mass Extinction: New evidence from volcanic ash layers in the Lower Yangtze Region. J. Asian Earth Sci. 2016, 127, 197-210. [CrossRef]

103. Xiao, L.; Xu, Y.; Mei, H.; Zheng, Y.; He, B.; Pirajno, F. Distinct mantle sources of low-Ti and high-Ti basalts from the western Emeishan large igneous province, SW China: Implications for plume-lithosphere interaction. Earth Planet. Sci. Lett. 2004, 228, 525-546. [CrossRef]

104. Li, Y.; He, H.; Ivanov, A.V.; Demonterova, E.I.; Pan, Y.; Deng, C.; Zheng, D.; Zhu, R. ${ }^{40} \mathrm{Ar} /{ }^{39} \mathrm{Ar}$ age of the onset of high-Ti phase of the Emeishan volcanism strengthens the link with the end-Guadalupian mass extinction. Int. Geol. Rev. 2018, 60, 1906-1917. [CrossRef]

105. Zhu, J.; Zhang, Z.; Hou, T.; Kang, J. LA-ICP-MS zircon U-Pb geochronology of the tuffs on the uppermost of the Emeishan basalt succession in Panxian County, Guizhou Province: Constraints on genetic link between Emeishan large igneous province and the mass extinction. Acta Pet. Sin. 2011, 27, 2743-2751, (In Chinese with English abstract).

106. Dai, S.; Chekryzhov, I.Y.; Seredin, V.V.; Nechaev, V.P.; Graham, I.T.; Hower, J.C.; Ward, C.R.; Ren, D.; Wang, X. Metalliferous coal deposits in East Asia (Primorye of Russia and South China): A review of geodynamic controls and styles of mineralization. Gondwana Res. 2016, 29, 60-82. [CrossRef]

107. Jiang, W.; Peacor, D.R.; Okita, P.M. Hydrothermal and metamorphic berthierine from the Kidd Creek volcanogenic massive sulfide deposit, Timmins, Ontario. Can. Miner. 1992, 30, 1127-1142.

108. Taylor, K.G. Berthierine from the non-marine Wealden (Early Cretaceous) sediments of South-East England. Clay Min. 1990, 25, 391-399. [CrossRef]

109. Hornibrook, E.R.C.; Longstaffe, F.J. Berthierine from the lower cretaceous Clearwater formation, Alberta, Canada. Clays Clay Min. 1996, 44, 1-21. [CrossRef]

110. Iijima, A.; Matsumoto, R. Berthierine and chamosite in coal measures of Japan. Clays Clay Min. 1982, 30, 264-274. [CrossRef]

111. Liu, Q.; Zhang, P. The Composition and Mineralization Mechanism of Kaolinite Rocks in Late-Palaeozoic Coal Measures, North China; China Ocean Press: Beijing, China, 1997; pp. 43-46. (In Chinese)

112. Burton, J.H.; Krinsley, D.H.; Pye, K. Authigenesis of kaolinite and chlorite in Texas Gulf Coast sediments. Clays Clay Min. 1987, 35, 291-296. [CrossRef]

113. Rivard, C.; Pelletier, M.; Michau, N.; Razafitianamaharavo, A.; Bihannic, I.; Abdelmoula, M.; Ghanbaja, J.; Villiéras, F. Berthierinelike mineral formation and stability during the interaction of kaolinite with metallic iron at $90^{\circ} \mathrm{C}$ under anoxic and oxic conditions. Am. Miner. 2013, 98, 163-180. [CrossRef]

114. Humprheys, B.A.; Smith, S.A.; Strong, G.E. Authigenic chlorite formation in late Triassic sandstones from the Central Graben, North Sea. Clay Min. 1989, 24, 427-444.

115. Boles, J.R.; Franks, S.G. Clay diagenesis in Wilcox sandstones of southwest Texas: Implications of smectite diagenesis on sandstone cementation. J. Sediment. Pet. 1979, 49, 55-70.

116. Hower, J.C.; Eslinger, E.V.; Hower, M.E.; Perry, E.A. Mechanism of burial metamorphism of argillaceous sediments. Geol. Soc. Am. Bull. 1976, 87, 125-737. [CrossRef]

117. Rivas-sanchez, M.L.; Alva-valdivia, L.M.; Arenas-alatorre, J.; Urrutia-Fucugauchi, J.; Ruiz-Sandoval, M.; Ramos-Molina, M.A. Berthierine and chamosite hydrothermal: Genetic guides in the Peña Colorada magnetite-bearing ore deposit, Mexico. Earth Planets Space 2006, 58, 1389-1400. [CrossRef]

118. Zhao, L.; Dai, S.; Graham, I.T.; Wang, P. Clay mineralogy of coal-hosted Nb-Zr-REE-Ga mineralized beds from Late Permian Strata, Eastern Yunnan, SW China: Implications for paleotemperature and origin of the micro-quartz. Minerals 2016, 6, 45. [CrossRef]

119. Nriagu, J.O.; Moore, P.B. Phosphate Minerals; Springer: Berlin, Germany, 1984.

120. Smith, M.; Henderson, P.; Campbell, L. Fractionation of the REE during hydrothermal processes: Constraints from the Bayan Obo Fe-REE-Nb deposit, Inner Mongolia, China. Geochim. Cosmochim. Acta 2000, 64, 3141-3160. [CrossRef]

121. Berger, A.; Gnos, E.; Janots, E.; Fernandez, A.; Giese, J. Formation and composition of rhabdophane, bastnäsite and hydrated thorium minerals during alteration: Implications for geochronology and low-temperature processes. Chem. Geol. 2008, 254, 238-248. [CrossRef]

122. Guilbert, J.M.; Park, C.F., Jr. The Geology of Ore Deposits, 4th ed.; W.H. Freeman: New York, NY, USA, $1986 ;$ p. 985.

123. Dai, S.; Nechaev, V.P.; Chekryzhov, I.Y.; Zhao, L.; Vysotskiy, S.V.; Graham, I.; Ward, C.R.; Ignatiev, A.V.; Velivetskaya, T.A.; Zhao, L.; et al. A model for $\mathrm{Nb}-\mathrm{Zr}-\mathrm{REE}-\mathrm{Ga}$ enrichment in Lopingian altered alkaline volcanic ashes: Key evidence of $\mathrm{H}-\mathrm{O}$ isotopes. Lithos 2018, 302-303, 359-369. [CrossRef]

124. Ward, C.R.; Crouch, A.; Cohen, D.R. Identification of frictional ignition potential for rocks in Australian coal mines. In Safety in Mines: The Role of Geology; Doyle, R., Moloney, J., Rogis, J., Sheldon, M., Eds.; Coalfield Geology Council of New South Wales: Maitland NSW, Australia, 1997; pp. 169-175. 